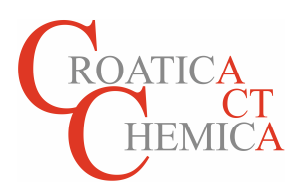

\title{
Autobiographical Notes
}

\author{
Nenad Trinajstić \\ The Rugjer Bošković Institute and \\ Croatian Academy of Sciences and Arts, Zagreb, Croatia
}

\section{FAMILY BACKGROUND}

WAS born in Zagreb (Croatia) on October 26, 1936. My parents were Regina (née Pavić) (April 17, 1916, ZagrebMarch 9, 1992, Zagreb) and Cvjetko Trinajstić (September 9, 1913, Volosko-October 29, 1998, Richmond, Australia). My maternal grandparents came to Zagreb in the last decade of the $19^{\text {th }}$ century from northern Dalmatia whilst my paternal grandparents lived all their lives in Volosko, a small town located between Rijeka and Opatija. Rijeka is a large seaport and Opatija is a well-known summer and winter resort. My younger brother Ivan (born in 1938 in Zagreb) and I spent the four years during the Second World War (1941-1945) in Volosko with our paternal grandparents. Our parents were divorced in 1946, father moved first to Italy, where he remarried and emigrated to Australia, whilst Ivan and I remained with our mother in Zagreb. Our mother encouraged us to read books, learn languages and be good students. My brother took degrees in physics and mathematics, moved back to Volosko and taught in Rijeka, Opatija and finally in Matulji, a place above Volosko, where he was until retirement the principal of a primary and junior secondary school. He is married, has two sons (Slaven and Nenad) and a granddaughter (Emma). His older son Slaven has lived in Toronto since 1993, he is now a Canadian citizen and his daughter Emma was born in Toronto.

The origin of the family name Trinajstić is linked to the number 13 . This number appears as the root word in the family name Trinajstić: $13-i c ́$ - 13 = trinajst in the Čakavian dialect of the Croatian language; the Croatian language has 3 dialects: Čakavian, Kajkavian and Štokavian. ${ }^{[1]}$ The family name Trinajstić is an old Croatian family name (it can be traced back several centuries in the place now called Trinajstići, located near Matulji) and belongs to a class of Croatian family names with numbers in their roots. ${ }^{[2]}$ Šmunović, ${ }^{[2]}$ an in authority on the origin of Croatian family names, hypothesized that the Croatian family names reflecting a certain number were motivated by the order of birth in old patriarchal families. Thus, the thirteenth born child got the nickname Trinajstić (the thirteenth, 13 and ić meant the smallest), which later became the family name of the child's descendents and has remained so until today. Šimunović[ ${ }^{2]}$ also mentioned very briefly the possibility that the family name Trinajstic originated from the folk belief in the magic of the number 13. Anyway, whatever the origin of the family name Trinajstić, the number 13 is a lucky number for the Trinajstić clan, which is now dispersed over five continents, although in some cases the name has undergone changes, e.g., the part of the clan in California is now called Trinast (presumably an immigration clerk on the Ellis Island had trouble spelling the name Trinajstić and consequently americanized it to Trinast). Professor Sven J. Cyvin (1931-2013) (Trondheim, Norway) liked the idea of using the alphanumeric family name of mine so much that he and his coworkers dedicated a paper to me, using 13-ić as my family name, ${ }^{[3]}$ on the occasion of my appointment to the position of Editor-in-Chief of Croatica Chemica Acta, the chemistry journal published by the Croatian Chemical Society since 1927.

\section{SCHOOL DAYS}

I started primary school in 1944 in Volosko and in Trieste, but because of the bombing of Rijeka and Trieste by the Allies, especially in the spring of 1945, this was a highly irregular schooling. For the second form I was already in Zagreb where I attended a downtown primary school. In those days, primary schooling in the former Yugoslavia lasted 7 years and was modeled after the Soviet system of seven-year elementary school called sedmoljetka. At about the age of nine I started doing chemical experiments. Several friends in the house where we lived in downtown Zagreb (I was born in that house) decided to make gunpowder. I joined them and we 
produced some lovely explosions in the cellar. These experiments lasted until our parents forbade us to continue after a particularly violent explosion that shook the whole building. I finished the seven-year school in 1951. One of the many changes in the Croatian school system happened in that year and the seven-year school was extended to the eight-year primary school (educational legislators now want to extend primary schooling to nine years). Thus, all of us who finished the seven-year primary school had to do five years of secondary school (instead of four like the several generations before us) that ended in the final examination called matura. One good point of the type of schooling I had was that we had lectures in chemistry from the fifth form of the sevenyear school and throughout all five years of high school, making a total of 8 years of chemical education. Later generations had at best 5 years of chemical education. At high school I met my future wife Judita née Juričev (born in Zagreb in 1938); she was in the same class with my brother Ivan. I even remember the date we met-September 21, 1954. We have remained together ever since that day. We were married in 1960 and have two children (Regina, born in 1960, and Dean, born in 1965; both born in Zagreb). I graduated from high school in 1956 and the same year entered the University of Zagreb, enrolling in the Department of Chemical Technology at the Technical Faculty. Years of my primary and secondary schooling were difficult because of the postwar shortage of practically everything. Nevertheless, with the little money we had my mother always bought books that Ivan and I needed for school and books we liked to read. In this way, Ivan and I became acquainted with a number of literary masterpieces and since those days I have been an avid reader and collector of books. My personal library has nowadays reached some 15,000 books, including hundreds of scientific books and journals.

\section{UNIVERSITY}

Chemistry was only my second choice. I actually wanted to study philosophy. A few days before enrolment, I went to the Alps with a group of friends and asked my mother to take my documents to the Department of Philosophy. I spent two weeks climbing various Alpine peaks. Upon returning to Zagreb, I found to my astonishment that my mother had entered me into the Department of Chemical Technology at the Technical Faculty. We had a long talk and my mother convinced me that chemistry was a better choice for me. During my school days, I read biographies of Louis Pasteu (18221895) and Justus von Liebig (1803-1873) and their lives and achievements in chemistry and science influenced me so much that I wanted to imitate them. I, therefore, started to read chemical books and to do experiments in our school lab and in the analytical laboratory of the nearby Faculty of Pharmacy (now called the Faculty of Pharmacy and
Biochemistry). Our apartment was fairly large and my mother, in need of money, used to rent a room to two students studying pharmacy who were undergraduate lab assistants. Thus, almost every weekend I went to their lab with them to do simple analytical experiments. This activity lasted about a year and a half. Then, the room was rented to a student attending the Department of Chemical Technology, who was an undergraduate lab assistant in organic chemistry. Thus, I occasionally went with him to his lab (which again was located close to our house) and did some simple organic syntheses and purification of solvents. Those visits to the organic chemistry lab went on for about a year until this student left Zagreb. Then my interest suddenly focused on philosophy. I accidentally came by a book on Plato (427-347 B.C.) and his philosophy and my enthusiasm for chemistry was shifted to philosophy. I became a Platonist and have remained the Platonist ever since. I read and reread Timaeus and even started to learn Greek to avoid translations that I did not trust. It should be pointed out that in those days Marxism was the official philosophy of the former Yugoslavia. I had a number of arguments with my philosophy teacher by contrasting Plato's beautiful philosophy and his masterly writings to Marxism as an economic theory and not a sound philosophical foundation upon which to build the society. My mother warned me that if I wanted to study philosophy and oppose Marxism, which was the basis of the communist ideology, I would end up in prison. In those days one could be imprisoned for any kind of opposition to the communists, even philosophical. My mother also said that, as a chemical engineer, I would be safe even if I sometimes said something that the communists disliked. Thus, I started chemical studies and returned to my first love, to chemical research. I should also mention that Vladimir Prelog (19061998), the Croatian Nobel laureate in chemistry for 1975 (sharing the Prize with John Warcup Cornforth, 1917-2013), was professor of organic chemistry in the Department of Chemical Technology from 1935 to 1941, when he moved to Eidgenössische Technische Hochschule (ETH) in Zürich. I studied chemical technology uneventfully from 1956 to 1960 and did research in polarography for my degree thesis under Professor Ivan Filipović of Heldenthal (1911-1998), ${ }^{[4]}$ whose undergraduate lab assistant I became in the second semester. The degree thesis was entitled Influence of $\mathrm{pH}$ on the Half-Wave Potential of Bismuth in Solutions of Sodium Acetate and Acetic Acid. After getting a degree in chemical technology, at the beginning of November 1960 I joined the research department of PLIVA, then and now the largest pharmaceutical company in the southeast of Europe. The powerful broad-spectrum antibiotic called azithromycin was discovered in PLIVA. It is sold in Croatia as SUMAMED and was licensed by PFIZER as ZITHROMAX. In the early 1962, I left PLIVA and joined the Rugjer Bošković Institute in Zagreb. I did this because I wanted to enroll in the graduate school at 
the University of Zagreb and the Rugjer Bošković Institute was in those days an ideal place for graduate research. This move of mine was largely influenced by a good friend from student days - the late Krešimir Humski (1939-1997) ${ }^{[5]}$ (later professor of organic chemistry in the Faculty of Technology and at the Faculty of Pharmacy and Biochemistry). When Humski got married, I was his best man. He suggested I should join the Laboratory of Physical Organic Chemistry in the Institute whose head was Dionis Emerik Sunko (19222010) (later professor of organic chemistry in the Department of Chemistry at the Faculty of Natural Sciences and Mathematics). Besides Sunko, the leading chemist in this laboratory was the late Stanko Borčić (1931-1994) (later professor of organic chemistry at the Faculty of Pharmacy and Biochemistry), who got his Ph.D. from ETH doing research under Leopold Ružižka (1887-1976) and Prelog, two Croatian Nobel laureates in chemistry (Ružička shared the Nobel Prize in 1939 with Adolph F. J. Butenandt).

\section{M.Sc., Ph.D. DEG REES AND POSTDOCTORAL RESEARCH}

I started M.Sc. studies in organic chemistry and biochemistry. But, after a year I switched to physical chemistry, the reason being that both Humski and I got in trouble with the late Professor Krešimir Balenović (1914-2003). ${ }^{[6]}$ At that time, he was the leading Croatian organic chemist, collaborator of three Nobel laureates: Albert Szent-György (1893-1986), Ružička and Prelog, and head of the M.Sc. program in organic chemistry and biochemistry. Božo Težak (1907-1980), ${ }^{[7]}$ the leading Croatian physical chemist at that time, was the head of the M.Sc. program in physical chemistry. He accepted us into his program and this change was also approved by Sunko. During coffee breaks, a regular visitor to our lab was Milan Randić (1930), ${ }^{[8]}$ who had came back to the Institute in 1958 after getting his Ph.D. from the Cambridge University. Research for his thesis Some Studies in Infrared Spectra of Molecules was carried out under Professor Norman Sheppard, FRS (1921-2015). In Cambridge, Randić met John Norman Murrell, FRS (1932-2016) who was working for his Ph.D. degree under Professor Hugh Christopher LonguetHiggins, FRS (1923-2004). They became good friends and, besides Randić, Murrell played a crucial role in the early development of quantum chemistry in Croatia. ${ }^{[9]}$ At the graduate school in Zagreb, Randić lectured on Quantum Chemistry and Symmetry in Chemistry in the M.Sc. program in physical chemistry. His lectures were very stimulating and during coffee breaks we talked a lot about quantum chemical problems. At that time, Randić was developing the maximum overlap approach to strained systems using a paper by Coulson and Moffitt ${ }^{[10]}$ as the starting point. I liked his lectures and I liked to talk with him so I finally decided to do research for my M.Sc. degree under his supervision. Most of the work for my M.Sc. degree was completed by the summer of 1963. I applied the Coulson-Moffitt maximum overlap approach, in a modified form, to all possible methyl-substituted cyclopropanes. However, before I could get the master's degree, I was called up for the compulsory army service in autumn of 1963. I could not avoid it, though I tried, and thus I spent the next 11 miserable months in Banja Luka (Bosnia and Herzegovina). That time was not completely wasted, because I read a lot - I read more than 150 books on science, philosophy and literature. Near the end of my army service, while I was waiting to be discharged, I was on guard duty at the army car depot guarding thousands of cars and tons and tons of gasoline. One day while on guard duty I was thinking about what to do after the army - should I get my master's degree and work in industry or perhaps continue to do research for a Ph.D. degree, but with whom, since Randić was abroad and I had learnt he was moving from Sheffield to Ottawa, when suddenly a car appeared with the officer in charge of the depot. He brought me a telegram from the Institute. The message it contained changed my destiny. The Institute's authorities asked me if I would like to go to the University of Sheffield and do predoctoral research under John Murrell. My answer was an emphatic Yes! It appears that somebody else was asked this first, but his wife did not want to leave Zagreb and her job. I was the second on the list of possible candidates. I returned from the army in late August of 1964 and already in early October I was in Sheffield in Murrell's group. Since I left Zagreb so quickly, I again had to postpone the orals for the M.Sc. degree. This position in Murrell's Group was offered to the Rugjer Bošković Institute upon Randić's suggestion. While I was in the army, Randić spent a year with Murrell in Sheffield and when Murrell told him that he had got this Royal Society grant, Randić suggested that it be given to somebody from Zagreb. When the Institute proposed me for this position, Randić strongly recommended me to Murrell and I was accepted. After several years in Sheffield, in 1965 Murrell moved to the new University of Sussex in Falmer near Brighton, where he became professor of physical chemistry and stayed there until his retirement, being, among other things, the chair of the Chemistry Department and the Vice-chancellor of the University. He was also elected to the Royal Society. I stayed with Murrell from October 1964 to June 1966, first at the University of Sheffield and when he moved to Sussex, I went with him and a part of the group to the University of Sussex. Later on, several young people from the Institute spent some time with Murrell (e.g., Tomislav Živković (1943)) and some even won Ph.D. degrees working with him (e.g., Slobodan Danko Bosanac (1946)). After I left Sussex, I occasionally visited Murrell and he came many times to Zagreb and to the theoretical chemistry meetings and summer schools on quantum chemistry held in Croatia (Dubrovnik, Brijuni). 
In Sheffield I met Harry Kroto, the future Professor Sir Harold Walter Kroto, FRS (1939-2016), a Nobel laureate for chemistry (he shared the 1996 Prize with Robert F. Curl (1933) and Richard E. Smalley (1943-2005) for their discovery of buckminsterfullerene). Kroto was a nice friendly person. He did Ph.D. research in spectroscopy under Richard Dixon (1930). The late Professor George Porter, FRS (19202002), ${ }^{[11]}$ also a future Sir and Nobel laureate for chemistry (he shared the 1967 Prize with Ronald W.G. Norrish (18971978) and Manfred Eigen (1927) for their work on ultrafast reactions), was head of the Physical Chemistry Department at that time.

In Murrell's group I met several people with whom I have remained in contact ever since. One of them is Stuart Carter, later a postdoctoral fellow with Randić in Zagreb. In the ensuing years, he visited my brother and me several times in Volosko. In Sheffield, Stuart Carter patiently taught me the correct pronunciation of many English words. I came to England with a good passive knowledge of the language but had never before spoken to an English person. Carter has a natural gift for languages and during his stay in Zagreb learned to speak decent Croatian. From 1986 to 1989 I used to spend three weeks each year in the Department of Chemistry of the University of Reading on a British Council grant. There I was located in the lab of the well-known molecular spectroscopist Professor lan Mills, FRS. Carter was also associated with Mills and during my stays in Reading we did a lot of collaborative research e.g., Ref. [12] Another member of Murrell's group Alan Hinchliffe helped me with programming. In Sheffield we had used an old Feranti computer, and that was my first encounter with computers. After getting a Ph.D. from the Sheffield University, Hinchliffe joined the University of Manchester Institute of Science and Technology where he was reader in chemistry. He is now retired. After both of us left Murrell's group, we published several papers together e. g., Refs. $[13,14]$ He did important research in chemical modeling and wrote, to my mind, the best book in the field, which had already had two editions. ${ }^{[15]}$ He was also senior reporter for the specialist periodical report entitled Chemical Modelling - Applications and Theory, published by the Royal Society of Chemistry.

I studied several problems with Murrell - I did some experimental work on determining the kinetics of unsymmetrical quinone-hydroquinone redox reactions, ${ }^{[16]}$ used the Pariser-Parr-Pople (PPP) SCF MO method to interpret the UV/VIS spectra of alternant hydrocarbon anions and cations ${ }^{[17]}$ and reported a few original criteria for obtaining localized orbitals. ${ }^{[18]}$ Altogether, I produced 7 papers during my stay with Murrell and he agreed that this productivity and its quality would make an acceptable Ph.D. thesis. I returned to Zagreb and obtained and M.Sc. degree first, because in those days an M.Sc. degree was a prerequisite for the Ph.D. The title of my M.Sc. thesis was The Method of Maximum Overlap and Its Application to Calculation of Hybrids in Some MethylSubstituted Cyclopropanes (University of Zagreb, 1966). Part of the M.Sc. thesis was published in 1965 and this was my first published research paper. ${ }^{[19]}$ This was also the first of 76 papers that Randić and I published together over the years. As soon as I got my M.Sc. degree, I submitted my Ph.D. thesis, based on the papers published while I was with John Murrell, to the Faculty of Natural Sciences and Mathematics. The thesis was accepted and I defended it in early January 1967. My Ph.D. thesis was entitled Electronic Structure of Some Polyatomic Molecules (Zagreb, 1967). My M.Sc. and Ph.D. theses were the first theses in quantum chemistry in Croatia.

In 1967, Randić organized the first quantum chemistry school in the former Yugoslavia and I helped him with the organization. The school was held at Herceg-Novi, a city in the Bay of Kotor. At that school I met Professor Michael J. S. Dewar, FRS (1918-1997), ${ }^{[20]}$ who invited me to join his group at the University of Texas (Austin) as a Robert A. Welch postdoctoral fellow. I described how I met Dewar in my article How I Met Michel Dewar. This article appeared in A Group Memoir (University of Texas, Austin, 1988) containing a collection of memories and tributes written by his present and former students and colleagues, which was dedicated to Dewar on the occasion of his $70^{\text {th }}$ birthday and given to him at the International Symposium on Physical Organic/ Theoretical Chemistry held in his honor in Austin on February 25-28, 1988. I wonder why Dewar was never awarded a Nobel Prize in chemistry? He was a brilliant scientist, developed the PMO theory and a semiempirical MO method of high accuracy that was widely used. He was also a highly educated person who possessed a vast knowledge of art and literature, who appreciated good food and wine, but with his sharp criticisms easily made enemies (perhaps this is the reason why he was never given the Prize!).

In Austin, my family and I spent two wonderful years (1968-1970). I was doing the SCF MO and MINDO studies of various large molecular systems and their properties e.g., Refs. [21-24] and produced 16 papers with Dewar. This research of mine and of Dewar's other postdocs was a precursor of the AM1 (Austin Model One) method - the paper introducing the AM1 was the second most cited paper published in the Journal of American Chemical Society (JACS) in its 125 years. ${ }^{[25]}$ The list containing the 125 most cited papers published in JACS can be found on the Web: http://pubs.acs.org/journals/jacsat/125promotion/articles/htm I. Dewar has several more papers on this list. For example, his paper with Walter Thiel on the MINDO method is the third on the list. In Austin, I met Douglas J. Klein (1942), who was at that time doing Ph.D. research under Professor Frederic Albert Matsen (1913-2006). After being a postdoctoral fellow in several places, Klein settled down as a professor of chemistry in the Department of Marine Sciences, Texas A \& $M$ University at Galveston. I have visited him there many 
times and on several occasions I spent three months working with him and several other professors in the Theoretical Chemical Physics Group that Klein was heading. Collaboration with Doug Klein and his colleagues was very productive and we have published over the years a number of research papers e.g., Refs. [26-28].

\section{YEARS AT THE RUGJER BOŠKOVIĆ INSTITUTE}

After returning from England in 1966, I joined the Theoretical Chemistry Group in the Department of Physical Chemistry of the Institute and stayed there until mandatory retirement at the end of 2001. The retirement age in Croatia is 65. The Theoretical Chemistry Group was founded by Randić on his return from Cambridge. My advancement in the Department was as follows: I became a research scientist in 1967, an associate research professor in 1971 and a full research professor in 1977. I was head of the Theoretical Chemistry Group for many years and chairman of the Physical Chemistry Division from 1997-2001. I was also lucky to be continuously supported by grants from various Croatian granting agencies.

When Randić left Zagreb for good in 1971, I took over his lectures in quantum chemistry in the Department of Chemistry of the Faculty of Natural Sciences and Mathematics. There I was first elected to the position of assistant professor in 1970, then associate professor in 1973, and finally in 1977 I was promoted to the rank of full professor. I also lectured on molecular orbital theory in the graduate school. To help graduate students, I wrote a book entitled Molecular Orbitals in Chemistry (Školska knjiga, Zagreb, 1974; this book was translated by my doctoral student Gani Jashari (1952) into Albanian for the use of students in Albania and at the University of Prishtinë in Kosovo). This was the first book on molecular orbital theory in the Croatian language. Later, Leo Klasinc (1937), Zvonimir Maksić (1938-2011) and I wrote a book for undergraduate students on the use of symmetry in quantum chemistry, entitled Symmetry of Molecules (Školska knjiga, Zagreb, 1979). I also supervised 16 B.Sc. degree theses, 9 M.Sc. theses and 18 Ph.D. theses. Among the students who were awarded their B.Sc degrees under my supervision, Zlatko Bačić (1954) is now a professor at the New York University and one of the leading chemical physicists in the USA. He got his Ph.D. degree from the University of Utah and received the Camille and Henry Dreyfuss Fellowship. Boris Sinković got his B.Sc. degree with me, his Ph.D. degree from the University of Hawaii and is presently professor of physics at the University of Connecticut (Storrs). He runs highly regarded research in surface physics. Milorad Milun (1947), who got all three degrees, B.Sc., M.Sc. and Ph.D., under my supervision, is retired, but used to be the director of the University Institute of Physics in Zagreb and a leading Croatian researcher in vacuum physics and nanotechnology. Ivan Gutman (1947) obtained M.Sc. and Ph.D. degrees with me and later he was also awarded a Ph.D. degree in mathematics from the University of Belgrade (Serbia). His M.Sc. thesis (Graph Theory and Molecular Orbitals, University of Zagreb, 1973) and his Ph.D. thesis (Investigation of Topological Properties of Conjugated Hydrocarbons, University of Zagreb, 1973) were the first theses in mathematical chemistry in Croatia. Gutman is one of the international leaders in mathematical chemistry and used to be the professor of physical chemistry at the University of Kragujevac (Serbia). He is also a current Editor-in-Chief of MATCH - Communications in Mathematical and in Computer Chemistry, an international periodical, established in 1975 by late Professor Oskar E. Polansky (1919-1989), ,30] for the publication of research work in the overlapping area between discrete mathematics and chemistry as well as for its applications in computer chemistry. Borka Džonova-Jerman-Blažič was head of the computer networking research at the Josef Stefan Institute in Ljubljana (Slovenia). Her Ph.D. thesis Computer-Aided Solutions of Some Nonnumerical Problems in Chemistry (University of Zagreb, 1981) was the first thesis in computer chemistry in Croatia. Sonja Nikolić (1954) is a distinguished research professor in the Institute Rugjer Bošković. Her Ph.D. thesis Chemical Graphs - ConjugatedCircuit Model: Selection of Parameters and Applications of the Model (University of Zagreb, 1988) contains a scholarly review of the conjugated-circuit model, gives its quantummechanical basis and presents its extension to heteroconjugated polycyclic molecules. Bono Lučić (1964) has an interesting background: he got his bachelor's degree from the Department of Electrical Engineering, his master's degree from the Department of Physics and his Ph.D. degree from the Department of Chemistry of the Faculty of Natural Sciences and Mathematics. He did research for his Ph.D. degree in chemistry under my supervision, whilst his M.Sc. thesis was supervised by the well-known Croatian biophysicist Professor Davor Juretić. In his Ph.D. thesis, entitled Quantitative Structure-Property-Activity Relationships of Molecules: The Use of Ordered Orthogonalized Descriptors (University of Zagreb, 1997), Lučić took advantage of his broad education. Iva Maria Tolić (1974) got the first Croatian Ph.D. in theoretical biology with her dissertation Cells as Tensegrity Structures (University of Zagreb, 2002). She completed the experimental part of the thesis at Harvard University working with Professor Ning Wang. Tensegrity is a contraction of terms tensional integrity. This word was coined by Buckminster Fuller (1895-1983). Buckminsterfullerene, named after him, ${ }^{[31]}$ the now famous $\mathrm{C}_{60}$ molecule with the structure of a truncated icosahedron, is also a tensegric structure. 


\section{RESEARCH}

I have been lucky to have good teachers (Filipović, Randić, Murrell, Dewar), gifted students from Croatia and abroad, good co-workers all my life and to have done joint research with most of the leading mathematical chemists of our time. Some of them have already been mentioned and some will be mentioned below. From the early days, I learnt to cooperate and appreciate the results of my colleagues and I have published research papers jointly with more than 250 scientists of various backgrounds. I have published extensively with some of them because I liked to collaborate with them because they were and are very nice persons, and research has always been an enjoyable occupation for me. In this way, doing science was like an exciting journey into the unknown in good company.

My research interests lie in the fields of quantum chemistry, mathematical chemistry, computer chemistry, history of chemistry and especially in the history of Croatian chemistry. Two topics prevailed in quantum chemistry: development of the semi-empirical molecular orbital (MO) theory applicable to large (heterocyclic) molecules ${ }^{[13,14,17,21-}$ 24,32,33] and setting up, in collaboration with Douglas J. Klein, Milan Randić and Sonja Nikolić, a valence-bond model, named the conjugated circuits model (originated by Randić[34] in 1976), on a firm quantum-mechanical basis, its parameterization and application to different classes of conjugated molecules and fullerenes. ${ }^{[35-40]} \mathrm{I}$ also did some $a b$ initio computations with the late Andrej Ažman (19371980), ${ }^{[41]}$ who was a senior scientist at the then Boris Kidrič Institute in Ljubljana (now the Slovenian National Institute of Chemistry; Slovenia became independent in 1991) and MO interpretations of photoelectron spectra of biologically active molecules with Leo Klasinc (1937) e.g., Ref. [42]. With Klasinc and his doctoral students Branko Ruščić (1952, presently a senior scientist at the Argonne National Laboratory, Argonne, Illinois) and Aleksandar Sabljić (1950, retired head of the Physical Chemistry Division and a full research professor at the Rugjer Bošković Institute) we took the first photoelectron spectra of opiates, interpreted them and even discussed how their structure affects their bioactivity. ${ }^{[43]}$

In the field of mathematical chemistry, I worked on the development and application of graph theory to chemistry with several of my doctoral students (e.g., Ivan Gutman, Milorad Milun, Maria Barysz, Sonja Nikolić, late Albin Jurić, Dragan Amić) and many colleagues (e.g., Dragoš Cvetković, Milan Randić, Doug Klein, Tomislav Živković, Roger Blakeney Mallion, Danail Bonchev, late Ante Graovac, Dejan Plavšić, late István Lukovits, Subhash C. Basak). Gutman came to Zagreb with the knowledge of graph-spectral theory and the Sachs theorem (introduced in 1964 by Professor Horst Sachs (1927-2016), ${ }^{[44]}$ a distinguished mathematician from Ilmenau in the then East Germany; an issue of MATCH ${ }^{[45]}$ has been dedicated to him on the occasion of his $75^{\text {th }}$ birthday), which he learnt from Cvetković in Belgrade. When Gutman told me that Cvetković calls C.A. Coulson's and A. Streitwieser's Dictionary of $\pi$-Electron Calculations (W.H. Freeman \& Co., San Francisco, 1965) the book of graph spectra, it became evident that there was an isomorphism between the Hückel MO (HMO) theory and graph-spectral theory and we started to analyze the simple HMO theory in terms of graph-theoretical concepts and the Sachs theorem. ${ }^{[46]}$ In the MATCH issue dedicated to Sachs, Gutman described the impact of the Sachs theorem on theoretical chemistry. ${ }^{[47]}$ Later, during my visit to the Department of Theoretical Chemistry, University of Oxford, early in 1974, I collaborated with Mallion and A.J. Schwenk (1947) in applying the Sachs theorem to weighted graphs representing heteroconjugated molecules. ${ }^{[48,49]}$ My visit to Oxford coincided with a sad occurrence - Charles Coulson's demise - in fact, he died on the very day that I arrived at the Oxford University Department of Theoretical Chemistry: January 7, 1974. That Department had been created especially for Coulson, who held a Personal Chair in Theoretical Chemistry and had transferred to the position after 20 years as the Rouse Ball Professor at the Mathematical Institute and a Fellow of Wadham College, because the Rose Ball Chair is permanently attached to that College. By a private arrangement between him and the College, Coulson remained the Fellow of Wadham College until he died. Charles Adrian Coulson, FRS (1910-1974) was the leading theoretical chemist of those days in the United Kingdom and was a father figure to theoretical chemists all over the globe. ${ }^{[50]}$ I met Coulson during the Herceg-Novi School and shared long walks with him during which we discussed about many topics including the future of quantum chemistry. In the aftermath of Charles Coulson's death, Mark Sheard Child, FRS (1937) became Inter Regnum Head of Department. Then, Norman March, FRS was elected to the first Coulson Chair of Theoretical Chemistry (with an associated Fellowship at University College). When March retired, Mark Child became Coulson Professor of Theoretical Chemistry in his own right. At about that time (in 1994) the Theoretical Chemistry Department was amalgamated with, and absorbed into, the Physical Chemistry Department. However, the Coulson Chair of Theoretical Chemistry remained. When I was in Oxford in 1974, Mallion was in the course of completing his second Ph.D. thesis (called, in Oxford, a D. Phil.) under Coulson, his first thesis having been obtained from the University of Wales at Swansea, under Claude William Haigh. At Oxford, Mallion was a Research Lecturer of Christ Church. Schwenk got his Ph.D. degree from the University of Michigan (Ann Arbor), under Professor Frank Harary (1921-2005) and was a postdoctoral visitor to the Matematical Institute in Oxford. I met Harary there and he made me a gift a copy of the second edition of his now-famous book Graph Theory (Addison- 
Wesley, Reading, MA, 1971, $2^{\text {nd }}$ edition). The well-known graph-theoreticians E.M. Palmer and Lowell Wayne Beineke (1939) were in the same group of visitors. Another wellknown graph-theoretician, Robin James Wilson (1943), then Lecturer of Jesus College, was also a member of the Mathematical Institute.

After publishing our first paper on the relationship between the HMO and graph-spectral theory, ${ }^{[46]}$ we soon found that research in chemical graph theory was also being done by Alexandru T. Balaban (1931) in Bucharest, Dennis $\mathrm{H}$. Rouvray (1938) in South Africa, Haruo Hosoya (1936) in Tokyo, William C. Herndon (1932-2011) in El Paso (Texas), Roger Blakeney Mallion (1946) in Oxford and that, before them, Edgar Heilbronner (1921-2006) was very productive in this area while he was at ETH and that Coulson and Klaus Ruedenberg (1920) were also interested in this type of research. In his reminiscences about the Z-index Hosoya ${ }^{[51]}$ described how he came to Zagreb and met Gutman and me there. In July of 1973, Hosoya attended the International Conference on Quantum Chemistry in Menton. There he met Rouvray and Mallion. From Menton Hosoya proceeded to Basel to visit Heilbronner. From Basel he came to Zagreb and then went to see Balaban in Bucharest. Interestingly enough, I had a choice of attending either the conference in Menton or going to Prague to attend the Conference on Chemical Structure-Biological Activity Relationships: Quantitative Approach. I went to Prague and met there Corwin Hansch (1918-2011), Lemont Burwell Kier (1930), William B. Purcell, Rudolf Zahradnik (1928), the Peter A. Kollman (1945-2001) and many other QSAR practitioners. This was the first international meeting on QSAR. I wonder why Hosoya did not go to Prague instead of to Menton - the Conference in Prague would have been a much more rewarding meeting for him in the light of his work on the Z-index and its use in QSPR. ${ }^{[52]}$ Randić learnt about all this activity first from Balaban when he delivered a lecture at Harvard University at that time Randić was visiting Professor E. Bright Wilson (1908-1992) in the Department of Chemistry. ${ }^{[53]}$ Randić immediately realized the potential of chemical graph theory and started doing highly creative research in this area of theoretical chemistry, soon to become the leader in the field.

Our most interesting result in the graph-theoretical analysis of HMO theory is the formulation of topological resonance energy (TRE) as a measure of aromaticity of conjugated systems. ${ }^{[54,55]}$ The TRE theory was developed in collaboration with my doctoral students Ivan Gutman and Milorad Milun and its applications were extended to conjugated ions, radicals, ion-radicals and bridged annulenes with my diploma student Sinković and doctoral students Predrag Ilić[ ${ }^{[6]}$ and Sabljić. ${ }^{[57]}$ The TRE theory was based on the concept of acyclic polynomial. We had problems with calculating this polynomial, thus with the help of Bojan Mohar (1956), a mathematician from Ljubljana, a computer program was devised for computing the acyclic polynomial and the TRE values. ${ }^{[58]}$ Approximately at the same time, Jun-ichi Aihara (1944) in Japan derived the same type of theory, ${ }^{[59]}$ although he called the acyclic polynomial reference polynomial and TRE the A-II method. He later accepted our terminology whilst the acyclic polynomial became known as the matching polynomial. ${ }^{[60]}$ The TRE theory is nowadays accepted as a reliable theory of aromaticity e.g., Ref. [61].

I summarized our activities in analyzing the HMO theory with graph-theoretical tools in my article Hückel Theory and Topology. ${ }^{[62]}$ Professor G.A. Segal (1934) (University of California, Los Angeles) was visiting Oxford and heard my lecture with the same title. He was just editing volumes 7 and 8 of the series of books on modern theoretical chemistry and he liked my lecture and thought that, if written, it would nicely fit in his volume 7 , in which a theoretical framework of a number of semiempirical methods for computing electronic structures of molecules would be presented. I cast my lecture into the requested form and it appeared in that book as the first article.

I was also involved in the development of molecular descriptors known as topological indices, a term introduced by Hosoya in $1971^{[52]}$ and quantitative relationships between the structures, properties and activities of organic molecules and biomolecules (QSPR and QSAR modeling $-I$ believe that the term QSPR - quantitative structure-property relationship - was first used in print by Sabljić and me in 1981) ${ }^{[63]}$. I was prompted by the lectures on QSAR that I heard at the Prague Conference in 1973 to start doing QSPR and QSAR modeling. In collaboration with Randić, my doctoral students Dragan Amić, Bogdan Bogdanov, Bono Lučić and Sonja Nikolić, my younger colleagues Drago Bešlo, Zlatko Mihalić and Dejan Plavšić and a graduate student-volunteer, Ante Miličević, I introduced several novel molecular descriptors, such as the Harary index ${ }^{[64]}$ and the modified Harary index ${ }^{[65]}$ in honor of Professor Frank Harary, the detour index, ${ }^{[66-68]}$ the three-dimensional Wiener number, ${ }^{[69]}$ the connectivity index with a variable exponent, ${ }^{[70]}$ a modified Wiener index, ${ }^{[71]}$ a variable Wiener index ${ }^{[72 a]}$ and a sum-connectivity index. ${ }^{[72 b, 72 c]}$ Some of these descriptors have also been independently introduced by other people. For example, the Harary index was at about the same time derived by Ovidiu Ivanciuc, Teodor-Silviu Balaban (1958-2016) and Alexandru T. Balaban, but was given a different name - the reciprocal distance sum (RDSUM) index. Their report was published in the same issue of the Journal of Mathematical Chemistry as our paper. ${ }^{[73]}$ Later, Balaban and his co-workers accepted the suggested name - Harary index. ${ }^{[74]}$ This index is based on the chemists' intuitive expectation that distant sites in a structure should influence each other less than the near sites. Randić et al.[75] also considered the connectivity index with selected values of the exponent, while we considered all possible values in search of the optimal exponent, that is, an 
exponent that would produce the QSPR model with the lowest value of the standard error of estimate. Gutman and Žerovnik had considered the modified Wiener index before us, ${ }^{[76]}$ but only its mathematical properties, while we investigated its use in the QSPR modeling. Such oft-repeated research in this highly competitive area is easy to understand.

Gutman and I also developed a pair of rather simple topological indices, which are often referred to in the literature as Zagreb indices e.g., Refs. $[77,78]$. One index represents summation of all vertex-degrees squared and the other summation of edge-weights in terms of multiplied degrees of incident vertices. In our early work on the topological basis of the $\pi$-electron energy, these two indices appeared in the topological formula for the total $\pi$-energy of conjugated molecules ${ }^{[79]}$ and were first used as branching indices ${ }^{[80]}$ and later as topological indices in QSPR and QSAR studies. ${ }^{[77,78]}$ We should also mention that the famous connectivity index of Randić was also introduced as a branching index ${ }^{[81]}$ and only later used as a molecular descriptor, which in due course became the most exploited of all topological indices in QSPR and QSAR. ${ }^{[77,78]}$ Zagreb indices, similarly to the modified Wiener index, were also modified ${ }^{[82]}$ in such a way that the outer atoms and bonds gave a larger contribution to indices than the inner atoms and bonds, because the outer atoms and bonds are associated with a larger part of the molecular surface and are consequently expected to make a greater contribution to physical, chemical and biological properties. Variable Zagreb indices were also proposed. ${ }^{[83]}$ Danail Bonchev paid a visit to Zagreb in the spring of 1976. We used his stay to study the branching of acyclic structures using information-theoretic indices that we had derived from the distance matrix. ${ }^{[84]}$ In 1981, in collaboration with Ovanes Mekenyan, we derived the topological superindex as a sum of six information-theoretic indices that were derived from the orbits, chromatic properties, edges (and vertex-degrees), distances, radial distribution of vertices and the non-adjacent numbers of a graph. ${ }^{[85]}$ This index has shown a considerable discrimination power. A few years later (1983) Bonchev summarized all these efforts in a book in which he gave a survey of the application of infomationtheoretic indices in chemistry. ${ }^{[86]}$

With my doctoral student Lučić, a CROMRsel procedure was introduced. ${ }^{[87]}$ This is a very efficient computational procedure for selecting relevant descriptors for the property modeled and for obtaining the best possible QSPR models for a given number of descriptors within the multivariate regression. The procedure was then used for modeling several molecular properties in collaboration with Professor Dragan Amić (1953) from the University of Osijek, ${ }^{[88]}$ Professor Alan Roy Katritzky, FRS (1928-2014) and his group from the University of Florida (Gainesville) and Damir Nadramija and his group from PLIVA. ${ }^{[89-91]}$ Our strategy for building the structure-property-activity models is delineated in a paper prepared in collaboration with Mihalić and published in the Journal of Chemical Education, ${ }^{[92]}$ which appears to be used by quite a few researchers in QSPR and QSAR modeling.

I was also involved in combinatorial enumeration of various classes of molecules. In collaboration with Professor Jan von Knop (1943) and his group from the University of Düsseldorf, I developed several efficient algorithms for characterization, generation and enumeration of chemical structures. These efforts were summarized in our two books. ${ }^{[93,94]}$ Our most valuable results are the development of an algorithm based on the $\mathrm{N}$-tuple code for constructive enumeration of acyclic structures ${ }^{[95]}$ and an algorithm based on the DAST (dualist angle-restricted spanning tree) code for generation and enumeration of certain classes of polycyclic structures. ${ }^{[96]}$ The $\mathrm{N}$-tuple code lead to the development of compact codes ${ }^{[97-104]}$ and induces a unique labeling of atoms in acyclic structures. ${ }^{[97]}$ Every digit in an $\mathrm{N}$-tuple code belongs to a single atom; thence, the sequential appearance of the digits indicates sequential labeling of atoms.

Some enumerative work was also carried out in collaboration with Professor Sir Harold Walter Kroto, FRS (1939-2016; Nobel prize in chemistry 1996).[105] This happened in the following way. I was visiting the University of Sussex in May 1982 and gave a series of lectures on enumeration in chemistry. The lectures were well attended; Murrell was there as well as Harry Kroto. Throughout the lecture series I had an uneasy feeling I was boring my audience with such exotic concepts as the $\mathrm{N}$-tuple code, the boundary code, the DAST code, 1- and 2-factors or the counting trigonal, square and hexagonal animals. They were probably asking themselves what all that was good for? However, one person was diligently taking notes and asking penetrating questions during coffee breaks. This person was Kroto. A few years later, in the spring of 1985, I got a letter from Kroto asking if I could generate all the possible polyynes $\mathrm{CnHm}$ and related cyanopolyyenes $\mathrm{C} n \mathrm{HmN}$, which I did. Polyynes (cyanopolyynes) are molecules consisting essentially of long chains of carbon atoms (and one nitrogen atom) and it appears that our understanding of interstellar chemistry depends on their existence in the interstellar medium. Kroto wanted to know the size of each family of these structures and I supplied the requested data. Later on, we (Kroto, von Knop and his group and I) introduced the concept of a physical tree. ${ }^{[106]}$ This work was directly linked to our abovementioned effort, since in it we proposed a simple mechanism by which acyclic molecules could be formed in interstellar space and circumstellar shells. To do this, we introduced trees with the memory of their origin (e.g., physical trees to differentiate them from chemical trees, that is, trees without memory) and we indicated this by assigning labels to the vertices of a physical tree consecutively and each vertex to be labeled must be adjacent to an already labeled vertex. Certain interest was later shown in physical trees and it was 
pointed out that Morgan-trees ${ }^{[107]}$ were a subclass of physical trees. ${ }^{[108]}$ I hope that through my collaboration with Kroto and von Knop, I was able to show the usefulness of constructive combinatorial enumerations in chemistry even before the combinatorial libraries proved to be an imperative tool in chemical modeling, preparation of novel compounds and drug design. Furthermore, I did all kinds of enumerations such as the counting of Kekulé structures, conjugated circuits, various classes of graphs, etc. using a variety of original and transplanted methods. ${ }^{[109]}$ The first time I encountered the problem of enumerating Kekulé structures was in 1967 when Randić and I tried to extend our method for computing bond lengths in cyclopentadienyl ligands in the half-sandwich structures containing transition metals ${ }^{[110]}$ to various benzenoid ligands. We did not do much because at that time we did not know how to generate all valence structures (Kekulé, Dewar, excited structures) of a benzenoid hydrocarbon except by hand.

For some time I was also interested in producing criteria for accounting molecular complexity. The complexity ${ }^{[111]}$ (or as Mallion and I call it, the intricacy) ${ }^{[112]}$ of a molecule is characterized by its size (in terms of either the number of atoms and/or bonds), branching, cyclicity, the presence of heteroatoms, multiple bonds, chirality, symmetry, etc. We (Nikolić, Tolić, Ivo Baučić and I) used various definitions of Zagreb indices in considering the two-dimensional complexity of molecules, ${ }^{[113,114]}$ and Mallion and I used a reciprocal spanning-tree density as a new index of complexity (intricacy). ${ }^{[12]}$ Later, we (Nikolić, Tolić and I) prepared in collaboration with Gerta and Christoph Rücker a summary of currently used complexity indices, which appeared in a book Complexity - Introduction and Fundamentals, edited by Bonchev and Rouvray. ${ }^{[115]}$

In 1983, I wrote the first single-author book on chemical applications of graph theory Chemical Graph Theory (first edition in two volumes: CRC Press, Boca Raton, Florida, 1983, second revised edition in a single volume: CRC Press, Boca Raton, Florida, 1992). According the Science Citation Index, this book has been cited 2466 times to the end of a year 2016.

Regarding the history of chemistry, I mostly studied the events and persons relevant to Croatian chemistry, $[4,9,116]$ but I have also written about the history of quantum theory, ${ }^{[117,118]}$ about Roald Hoffmann (1937) and his research ${ }^{[119]}$ and translated some of his poems into Croatian, ${ }^{[120]}$ and commented part of my correspondence with Vladimir Prelog. ${ }^{[121]}$ With Randić I have written about a dozen less known early developments of chemical graph theory. ${ }^{[122]}$ । have also written several articles on the history of numbers and their uses in science and chemistry, e.g., with Lionello Pogliani (1943) and Randić on zero ${ }^{[123]}$ and one ${ }^{[124]}$ (the computer age is based on these two numbers: 0 and 1 ) and alone on the number five, ${ }^{[125]}$ and with Tolic on the manifestations of the number five in biology. ${ }^{[126]}$ We also published an article on the number $13 .{ }^{[127]}$ Later Pogliani published book entitled Numbers Zero, One, Two, and Three in Science and Humanities (Kragujevac, 2006, pp. 250).

I was interested in the uses of graph-theoretical matrices in chemistry. My research in this area resulted in a number of publications and two editions of the book entitled Graph Theoretical Matrices in Chemistry (the first edition University of Kragujevac, Kragujevac, 2007; the second edition CRC press/Taylor and Francis Group, Boca Raton, 2015). As I already mentioned I was interested in history of chemistry in Croatia. My studies in this direction already resulted in two monographs: N. Trinajstić, 100 Croatian Chemists, Školskla knjiga, Zagreb, 2002 and S. Paušek-Baždar and N. Trinajstić, Croatian Chemistry in the $20^{\text {th }}$ Century, Školska knjiga, Zagreb, 2014. Croatian Academy of Sciences and Arts published my book on my Life in Science (Zagreb, 2016).

Citations of my various contributions are rather modest. My $\mathrm{h}$ index is 55, the most cited paper is I. Gutman, M. Milun, N. Trinajstić, Graph theory and molecular orbitals. Nonparametric resonance energies of arbitrary conjugated systems, J. Am. Chem. Soc. 1977, 99, 1692-1704 (SCl=561) and citations of my papers is 13760 , of my books is 4937 and the total citations were 18697 (these numbers provided Bono Lučić).

I was given several awards for my research, such as the City of Zagreb Science Award in 1972, the Croatian National Award for Science in 1982, the Mid-America State Universities Association Distinguished Foreign Scholar Award in 1987 and Croatian State Award for Life Achivements in Science (2004). On the occasion of my $60^{\text {th }}$ birthday, my former and present students and colleagues from Zagreb and abroad organized on October 25, 1996 a day-symposium in conjunction with the Croatian Chemical Society, Faculty of Chemical Engineering and Technology and Matrix Croatica (Matica hrvatska). Two MATH/CHEM/COMP meetings (in 2002 and 2016) had a day-symposia in my honour.

Several journals published issues in my honour, such as Internet Electronic Journal of Molecular Design (2003, issues 7 to 12; 2004, issues 1 to 6), Croatica Chemica Acta (2004, 77, 1-414), Journal of Chemical Information and Modelling (2007, 47, 705-951), International Journal of Chemical Modeling (2015, 6, 1941-3955). It is interesting to note that Journal of Chemical Information and Modelling in 2010 has celebrated the $50^{\text {th }}$ anniversary. In the anniversary issue were listed 50 most cited papers published in this journal and 50 authors with the highest numbers of papers published in this journal. In the 50 years, this journal published about 10.000 papers. Among the 50 most cited papers are 5 papers from Croatian authors: 3 of Randić, one of Gutman and one of Mihalić, Nikolić and myself. Among the 50 most productive authors are tri Croatian authors: Randić the second, I am listed as the ninth and Gutman as $12^{\text {th }}$ most productive author in this journal. 


\section{OTHER MATTERS}

I have served and am still serving on editorial boards of several journals: Croatica Chemica Acta (1967-1994), Journal of Molecular Structure-Theochem (1985-1995), Journal of Mathematical Chemistry (1986-1989, and again since 1994), Computers and Chemistry (1989-2002), Symmetry (19891990), MATCH - Communications in Mathematical and in Computer Chemistry (since 1997), SAR \& QSAR in Environmental Research (since 1999), Gazophylacium (since 2000) and Computational Biology and Chemistry (since 2003). I am also a member of advisory boards of the Bulletin of the Chemists and Technologists of Macedonia (since 1995) and Polimeri (since 1998). Additionally, I was a co-editor-inchief of the Journal of Mathematical Chemistry (1990-1993; the other editor was the well-known mathematical chemist Paul G. Mezey who has been the editor-in-chief since 1993), the editor-in chief of Croatica Chemica Acta (1994-2005) and of Prirodoslovlje (2001-2008). I am a member of a number of societies, such as Matica Hrvatska (Matrix Croatica) the central Croatian cultural and publishing society established in 1842 (since 1955), Croatian Chemical Society established in 1926 (since 1960), Croatian PEN Club (since 1987), Brethren of the Croatian Dragon - an old Croatian fraternal and cultural society established in 1408 as the Knights' Order of Dragon (since 1991). I was elected to the Croatian Academy of Sciences and Arts (established in 1861) in 1992 as the $12^{\text {th }}$ chemist who became a regular member of the Academy and the first theoretical chemist ever. I am also a member of the International Academy of Mathematical Chemists since 2006.

Since my two-year postdoctoral stay at the University of Texas in Austin and return to Zagreb, I visited for shorter periods of time, from one to six months, the University of Trieste (visiting Professor Vinicio Galasso), the University of Utah in Salt Lake City (staying there with Professor Frank E. Harris (1929) in the Department of Physics), the University of South Carolina in Columbia (staying there on several occasions with Professor Benjamin M. Gimarc in the Department of Chemistry. Gimarc also twice spent some time in Zagreb with me), the University of Missouri at Kansas City (staying there on several occasions with Professor Jerry Ray Dias (1938) in the Department of Chemistry), the University of Düsseldorf (staying in the Computing Center with Professor Jan von Knop at least once a year since June 1973. I probably spent in toto more than three years there; thus, Düsseldorf became my home away from home). I also visited Texas A \& $M$ University at Galveston (staying on several occasions with Professor Douglas J. Klein in the Department of Marine Sciences), the Natural Resources Research Institute in Duluth (staying with Dr Subhash C. Basak in the Center for Water and the Environment. I met Basak in 1983, when we attended the
Symposium on Chemical Applications of Topology and Graph Theory, held at the University of Georgia, Athens, April 1822, 1983 and organized by Professor R. Bruce King (1938), the Chemical Research Center of the Hungarian Academy of Sciences in Budapest (visiting Dr István Lukovits (1944-2007), etc. A funny thing is that, although I am older than many of these fine scholars, somehow I have always felt them to be not so much my colleagues as the older brothers I have never had. Retirement has not removed me from science and research. I hope to continue to do modest research for a few more years to come.

Acknowledgment. I sincerely thank my family for their continuous support and all my teachers, former students, my colleagues and friends all over the world for their kindness, patience and help shown to me throughout my life. Of course, without my dear wife Judita nothing listed above would happen; her support since the day we met was decisive.

Supplementary Information. The list of all scientific papers, and other papers and contributions authored by Nenad Trinajstic are given in the supplementary file attached to the electronic version of this document, available at http://dx.doi.org/10.5562/cca3171

\section{REFERENCES}

[1] M. Moguš, A History of Croatian Language: Toward a Common Standard, Globus, Zagreb, 1995.

[2] P. Šimunović, Naša prezimena (Our Family Names), Nakladni zavod Matice Hrvatske, Zagreb, 1985.

[3] S. J. Cyvin, J. Brunvoll, B. N. Cyvin, Di-4-Catafusenes: A New Class of Polygonal Systems Representing Polycyclic Conjugated Hydrocarbons, Croat. Chem. Acta 1996, 69, 177-190.

[4] N. Trinajstić, 100 hrvatskih kemičara (100 Croatian Chemists), Školska knjiga, Zagreb, 2003, pp. 50-51.

[5] N. Trinajstić, Obituary - Krešimir Humski (19391997), Croat. Chem. Acta 1998, 71, A9-A16.

[6] N. Trinajstić, Obituary - Krešimir Balenović (19142003), Croat. Chem. Acta 2003, 76, A3-A4.

[7] N. Trinajstić, Ogledi o znanosti $i$ znanstvenicima (Essays on Science and Scientists), Matica hrvatska, Zagreb, 1998, pp. 50-80.

[8] S. Nikolić, N. Trinajstić, Milan Randić - Life and Work, Croat. Chem. Acta 2002, 75, 319-327.

[9] N. Trinajstić, Quantum Chemistry in Croatia Beginnings, Kem. ind. (Zagreb) 2001, 50, 427-429.

[10] C. A. Coulson, W. E. Moffitt, I. Properties of Certain Strained Hydrocarbons, Phil. Mag. 1949, 40 (7), 1-35.

[11] D. Phillips, Obituary - George Porter (1920-2002), Nature 2002, 419, 578. 
[12] S. Carter, N. Trinajstić, S. Nikolić, On the Use of ID Numbers in Drug Research: A QSAR of Neuroleptic Pharmacophores, Med. Sci. Res. 1988, 16, 185-186; S. Carter, S. Nikolić, N. Trinajstić, A Novel Algorithm for QSAR, Int. J. Quantum Chem.: Quantum Biol. Symp. 1989, 16, 323-330; N. Trinajstić, S. Nikolić, S. Carter, QSAR: Theory and Application, Kem. ind. (Zagreb) 1989, 38, 469-484; S. Nikolić, N. Trinajstić, Z. Mihalić, S. Carter, On the Geometric-Distance Matrix and the Corresponding Structural Invariants of Molecular Systems, Chem. Phys. Lett. 1991, 179, 21-28.

[13] A. Hinchliffe, N. Trinajstić, Calculation of Proton Coupling Constants for Dibenzothiophene Radical Anion, Theoret. Chim. Acta 1968, 10, 458-460.

[14] A. Hinchliffe, N. Trinajstić, Electronic Properties of Conjugated lons, Theoret. Chim. Acta 1968, 11, 271273.

[15] A. Hinchliffe, Chemical Modeling - From Atoms to Liquids, Wiley, Chichester, 1999.

[16] S. Carter, J. N. Murrell, E. J. Rosch, N. Trinajstić, P. A. $H$. Wyatt, The Kinetics of Unsymmetrical QuinoneHydroquinone Redox Reactions, J. Chem. Soc. B 1967, 477-484.

[17] A. Hinchliffe, J. N. Murrell, N. Trinajstić, Calculation on the Energy Levels of Alternant Hydrocarbon Anions, Trans. Faraday Soc. 1966, 62, 1362-1369; N. Trinajstić, Molecular Orbital Calculations for Tetracene Monopositive Ion, Croat. Chem. Acta 1966, 38, 283-286.

[18] J. N. Murrell, J. G. Stamper, N. Trinajstić, Localized Orbitals of Water, J. Chem. Soc. A 1966, 1624-1627; J. G. Stamper and N. Trinajstić, Localized Orbitals for Some Simple Molecules, J. Chem. Soc. A 1967, 782784.

[19] N. Trinajstić, M. Randić, Maximum Overlap Hybridisation in Methyl Substituted Cyclopropanes, J. Chem. Soc. 1965, 5621-5624.

[20] J. N. Murrell, Michael James Steuart Dewar (24 September 1918-11 October 1997), Biog. Mems. Fell. R. Soc. Lond. 1998, 44, 127-140.

[21] M. J. S. Dewar, A. J. Harget, N. Trinajstić, Ground States of Conjugated Molecules. XV. Bond Localization and Resonance Energies in Compounds Containing Nitrogen or Oxygen, J. Am. Chem. Soc. 1969, 91, 6321-6325.

[22] M. J. S. Dewar, N. Trinajstić, Ground States of Conjugated Molecules. XX. SCF MO Treatment of Compounds Containing Bivalent Sulfur, J. Am. Chem. Soc. 1970, 92, 1453-1459.

[23] M. J. S. Dewar, D. H. Lo, D. B. Patterson, N. Trinajstić, G. E. Peterson, MINDO/2 Calculations of Nuclear Quadrupole Coupling Constants of Chlorobenzenes, J. C. S. Chem. Comm. 1971, 238-239.
[24] M. J. S. Dewar, M. C. Kohn, N. Trinajstić, Cyclobutadiene and Diphenylcyclobutadiene, J. Am. Chem. Soc. 1971, 93, 3437-3440.

[25] M. J. S. Dewar, E. G. Zoebisch, E. F. Healy, J. J. P. Stewart, AM1: A New General Purpose Quantum Mechanical Molecular Model, J. Am. Chem. Soc. 1985, 107, 3902-3909.

[26] D. J. Klein, N. Trinajstić, Hückel Rules and Electron Correlation, J. Am. Chem. Soc. 1984, 106, 8050-8056.

[27] D. J. Klein, T. Živković, N. Trinajstić, Resonance in Random $\pi$-Electron Polymers, J. Math. Chem. 1987, 1, 309-334

[28] N. Trinajstić, T. G. Schmalz, T. P. Živković, S. Nikolić, G. E. Hite, D. J. Klein, W. A. Seitz,p[N] henylenes: A Theoretical Study, New J. Chem. 1991, 15, 27-31.

[29] I. Lukovits, S. Nikolić, N. Trinajstić, On Relationship Between Vertex-Degrees, Path-Numbers and Graph Valence-Shells in Trees, Chem. Phys. Lett. 2002, 354, 417-422; I. Lukovits, N. Trinajstić, Atomic Walk Counts of Negative Order, J. Chem. Inf. Comput. Sci. in press; D. Amić, D. Davidović-Amić, D. Bešlo, N. Trinajstić, Structure-Radical Scavenging Activity Relationship of Flavonoids, Croat. Chem. Acta 2003, 76, 55-61.

[30] A. T. Balaban, A. S. Dreiding, A. Kerber, Oskar E. Polansky (1919-1989) and MATCH, MATCH Commun. Math. Computer Chem. 1989, 24, I-V.

[31] H. W. Kroto, J. R. Heath, S. C. O'Brien, R. F. Curl, R. E. Smalley, C60: Buckminsterfullerene, Nature 1985, 318, 162-163.

[32] N. Trinajstić, Calculation of Carbon-Sulphur Bond Lengths, Tetrahedron Lett. 1968, 1529-1532.

[33] J. N. Herak, N. Trinajstić, Free Valence Indices of Carbon in Heterocyclic Compounds, Theoret. Chim. Acta 1968, 9, 333-335.

[34] M. Randić. Conjugated Circuits and Resonance Energies of Benzenoid Hydrocarbons, Chem. Phys Lett. 1976, 38, 68-70. It appears that José A. N. F. Gomes discovered independently conjugatedcircuit model in 1976 while he was in Oxford doing Ph. D. research (private information by R. B. Mallion in his letter of March 24, 2003). See also J. A. N. F. Gomes, Why are the Properties of Polycyclic Hydrocarbons Additive over Conjugated Circuits?, Croat. Chem. Acta 1980, 53, 561-569.

[35] M. Randić, N. Trinajstić, Conjugation and Aromaticity of Corannulenes, J. Am. Chem. Soc. 1984, 106, 44284434.

[36] M. Randić, N. Trinajstić, J. von Knop, Ž. Jeričević, Aromatic Stability of Heterocyclic Conjugated Systems, J. Am. Chem. Soc. 1985, 107, 849-859.

[37] M. Randić, N. Trinajstić, On the Relative Stabilities of Conjugated Heterocycles Containing Divalent, Sulfur, Reports 1986, 6, 379-429. 
[38] M. Randić, S. Nikolić, N. Trinajstić, On the Aromatic Stability of a Conjugated $\mathrm{C} 60$ Cluster, Croat. Chem. Acta 1987, 60, 595-604.

[39] D. J. Klein, N. Trinajstić, Foundations of ConjugatedCircuits Models, Pure Appl. Chem. 1989, 61, 21072115.

[40] S. Nikolić, N. Trinajstić, D. J. Klein, The ConjugatedCircuit Model, Comput. Chem. 1990, 14, 313-322.

[41] J. Koller, A. Ažman, N. Trinajstić, Ab Initio Molecular Orbital Studies in Quantum Biology. Electronic Characteristics of Indole and Benzofuran, in: Quantitative Structure-Activity Relationships (Ed.: M. Tichy), Akademiai Kiado, Budapest, 1976, pp. 205-209.

[42] H. Güsten, L. Klasinc, J. von Knop, N. Trinajstić, Application of Photoelectron Spectrometry to Biologically Active Molecules and Their Constituent Parts. I. Indoles, in: Excited States of Biological Molecules (Ed.: J. B. Birks), Wiley, Chichester, Sussex, 1975, pp. 45-49.

[43] L. Klasinc, B. Ruščić, A. Sabljić, N. Trinajstić, Application of Photoelectron Spectroscopy to Biologically Active Molecules and Their Constituent Parts. VI. Opiate Narcotics, J. Am. Chem. Soc. 1979, 101, 7477-7482.

[44] H. Sachs, Beziehungen zwischen den in einem Graphen enthaltenen Kreisen und seinem charakterischen Polynom, Publ. Math. (Debrecen) 1964, 11, 119-134.

[45] MATCH - Commun. Math. Computer Chem. 2003, 48, 1-223.

[46] A. Graovac, I. Gutman, N. Trinajstić, T. Živković, Graph Theory and Molecular Orbitals. Application of Sachs Theorem, Theoret. Chim. Acta 1972, 26, 67-78.

[47] I. Gutman, Impact of the Sachs Theorem on Theoretical Chemistry: A Participant's Testimony, MATCH-Commun. Math. Computer Chem. 2003, 48, 17-34.

[48] R. B. Mallion, A. J. Schwenk, N. Trinajstić, A Graphical Study of Heteroconjugated Molecules, Croat. Chem. Acta 1974, 46, 171-182.

[49] R. B. Mallion, A. J. Schwenk, N. Trinajstić, On the Characteristic Polynomial of a Rooted Graph, in: Recent Advances in Graph Theory (Ed.: M. Fiedler), Academia, Prague, 1975, pp. 345-350.

[50] N. Trinajstić, Charles Alfred Coulson (1910-1974), Croat. Chem. Acta 1974, 46, A5-A6.

[51] H. Hosoya, The Topological Index Z Before and After 1971, Internet Electron. J. Mol. Des. 2002, 1, 428-442,

[52] H. Hosoya, Topological Index. A Newly Proposed Quantity Characterizing the Topological Nature of Structural Isomers of Saturated Hydrocarbons, Bull. Chem. Soc. Jpn. 1971, 44, 2332-2339.
[53] M. Randić, private communication.

[54] I. Gutman, M. Milun, N. Trinajstić, Topological Definition of Resonance Energy, MATCH - Commun. Math. Computer Chem. 1975, 1, 171-175.

[55] I. Gutman, M. Milun, N. Trinajstić, Graph Theory and Molecular Orbitals. XIX. Non-Parametric Resonance Energies of Arbitrary Conjugated Systems, J. Am. Chem. Soc. 1977, 99, 1692-1704.

[56] P. Ilić, N. Trinajstić, Topological Resonance Energies of Conjugated Ions, Radicals and Ion-Radicals, J. Org. Chem. 1980, 45, 1738-1748; P. Ilić, B. Sinković, N. Trinajstić, Topological Resonance Energies of Conjugated Structures, Israel J. Chem. 1980, 20, 258-269.

[57] A. Sabljić, N. Trinajstić, Aromatic Stability of Bridged Annulenes, J. Org. Chem. 1981, 46, 3457-3461.

[58] B. Mohar, N. Trinajstić, On Computation of the Topological Resonance Energy, J. Comput. Chem. 1982, 3, 28-36.

[59] J. Aihara, A New Definition of Dewar-Type Resonance Energies, J. Am. Chem. Soc. 1976, 98, 2750-2758.

[60] C. D. Godsil, I. Gutman, On the Theory of the Matching Polynomial, J. Graph Theory 1981, 5, 137-144.

[61] V. I. Minkin, M. N. Glukhovtsev, B. Y. Simkin, Aromaticity and Antiaromaticity, WileyInterscience, New York, 1994, pp. 14-19.

[62] N. Trinajstić, Hückel Theory and Topology, in: Semiempirical Methods of Electronic Structure Calculation. Part A: Techniques (Ed.: G. A. Segal), Modern Theoretical Chemistry, Vol. 7, Plenum, New York, 1977, pp. 1-27.

[63] A. Sabljić, N. Trinajstić, Quantitative StructureActivity Relationships: The Role of Topological Indices, Acta Pharm. Jugosl. 1981, 31, 189-214.

[64] D. Plavšić, S. Nikolić, N. Trinajstić, Z. Mihalić, On the Harary Index for the Characterization of Chemical Graphs, J. Math. Chem. 1993, 12, 235-250; K. Xu, K. Ch. Das, N. Trinajstić, The Harary Index of a Graph, Springer, Heidelberg, pp, 74.

[65] B. Lučić, A. Miličević, S. Nikolić, N. Trinajstić, Harary Index - Twelve Years Later, Croat. Chem. Acta 2002, 75, 847-868.

[66] D. Amić, N. Trinajstić, On the Detour Matrix, Croat. Chem. Acta 1995, 68, 53-62.

[67] N. Trinajstić, S. Nikolić, B. Lučić. D. Amić, Z. Mihalić, The Detour Matrix in Chemistry, J. Chem. Inf. Comput. Sci. 1997, 37, 631-638.

[68] S. Nikolić, N. Trinajstić, Z. Mihalić, The Detour Matrix and the Detour Index, in Topological Indices and Related Descriptors in QSAR and QSPR (Eds.: J. Devillers and A. T. Balaban), Gordon and Breach Science Publishers, The Netherlands, 1999, pp. 279-306. 
[69] B. Bogdanov, S. Nikolić, N. Trinajstić, On the ThreeDimensional Wiener Number, J. Math. Chem. 1989, 3, 299-309; J. Math. Chem. 1990, 5, 305-306. However, the earliest effort to use the 3-D Wiener index in QSPR/QSAR has been described in 0 . Mekenyan, D. Peitchev, D. Bonchev, N. Trinajstić, I. Bangov, Modelling the Interaction of Small Organic Molecules with Biomacromolecules. I. Interaction of Substituted Pyridines with Anti-3-azopyridine Antibody, Drug Res. 1986, 36, 176-183.

[70] D. Amić, D. Bešlo, B. Lučić, S. Nikolić, N. Trinajstić, The Vertex-Connectivity Index Revisited, J. Chem. Inf. Comput. Sci. 1998, 38, 819-822.

[71] S. Nikolić, N. Trinajstić, M. Randić, Wiener Index Revisited, Chem. Phys. Lett. 2001, 333, 319-321.

[72] (a) B. Lučić, A. Miličević, S. Nikolić, N. Trinajstić, On Variable Wiener Index, Indian J. Chem. A 2003, 42A, 1279-1282. (b) B. Zhou, N. Trinajstić, On a novel connectivity index, J. Math. Chem. 2009, 46, 12521270; (c) B. Lučić, N. Trinajstić, B. Zhou, Comparison between the sum-connectivity and productconnectivity indices for benzenoid hydrocarbons, Chem. Phys. Lett. 2009, 475, 146-148,

[73] O. Ivanciuc, T. - S. Balaban, A. T. Balaban, Design of Topological Indices. Part 4. Reciprocal Distance Matrix, Related Local Vertex Invariants and Topological Indices, J. Math. Chem. 1993, 12, 309-318.

[74] A. T. Balaban, O. Ivanciuc, Historical Development of Topological Indices, in: Topological Indices and Related Descriptors in QSAR and QSPR (Eds.: J. Devillers, A. T. Balaban), Gordon and Breach Science Publishers, The Netherlands, 1999, pp. 21-57.

[75] M. Randić, P. J. Hansen, P. C. Jurs, Search for Useful Graph Theoretical Invariants of Molecular Structure, J. Chem. Inf. Comput. Sci. 1988, 28, 60-68.

[76] I. Gutman, J. Žerovnik, Corroborating a Modification of the Wiener Number, Croat. Chem. Acta 2002, 75, 603-612.

[77] Topological Indices and Related Descriptors in QSAR and QSPR (Eds.: J. Devillers, A. T. Balaban), Gordon \& Breach, Amsterdam, 1999.

[78] R. Todeschini, V. Consonni, Handbook of Molecular Descriptors, Wiley-VCH, Weinheim, 2000; R. Todeschini, V. Consonni, Molecular Descriptors for Chemoinformatics, Wiley-VCH, Weinheim, 200

[79] I. Gutman, N. Trinajstić, Graph Theory and Molecular Orbitals. Total $\pi$-Electron Energy of Alternant Hydrocarbons, Chem. Phys. Lett. 1972, 17, 535-538.

[80] I. Gutman, B. Ruščić, N. Trinajstić, C. F. Wilcox, Jr., Graph Theory and Molecular Orbitals. XII. Acyclic Polyenes, J. Chem. Phys. 1975, 62, 3399-3405.

[81] M. Randić, On Characterization of Molecular Branching, J. Am. Chem. Soc. 1975, 97, 6609-6615; this paper is the 94th on the list of the 125 most cited JACS publications in the last 125 years.

[82] B. Lučić, A. Miličević, S. Nikolić, N. Trinajstić, The Zagreb Indices Thirty Years After, Croat. Chem. Acta 2003, 76, 113-124.

[83] A. Miličević, S. Nikolić, On Variable Zagreb Indices, Croat. Chem. Acta 2004, 77 89-95.

[84] D. Bonchev, N. Trinajstić, Information Theory, Distance Matrix, and Molecular Branching, J. Chem. Phys. 1977, 67, 4517-4533.

[85] D. Bonchev, Ov. Mekenyan, N. Trinajstić, Isomer Discrimination by Topological Information Approach, J. Comput. Chem. 1981, 2, 127-148.

[86] D. Bonchev, Information Theoretic Indices for Characterization of Chemical Structures, Research Studies Press/Wiley, Chichester, 1983.

[87] B. Lučić, N. Trinajstić, Multivariate Regression Outperforms Several Robust Architectures of Neural Networks in QSAR Modeling, J. Chem. Inf. Comput. Sci. 1999, 39, 121-132.

[88] B. Lučić, D. Amić, N. Trinajstić, Nonlinear Multivariate Regression Outperforms Several Concisely Designed Neural Networks on Three QSPR Data Sets, J. Chem. Inf. Comput. Sci. 2000, 40, 403413.

[89] B. Lučić, N. Trinajstić, S. Sild, M. Karelson, A. R. Katritzky, A New Efficient Approach for Variable Selection Based on Multiregression: Prediction of Gas Chromatographic Retention Times and Response Factors, J. Chem. Inf. Comput. Sci. 1999, 39, 610-621.

[90] A. R. Katritzky, K. Chen, Y. Wang, M. Karelson, B. Lučić, N. Trinajstić, T. Suzuki, G. Schüürmann, Prediction of Liquid Viscosity for Organic Compounds by a Quantitative Structure-Property Relationship, J. Phys. Org. Chem. 2000, 13, 80-86.

[91] B. Lučić, I. Bašic, D. Nadramija, A. Miličević, N. Trinajstić, T. Suzuki, R. Petrukhin, M. Karelson, A. R. Katritzky, Correlation of Liquid Viscosity with Molecular Structure Using Different Variable Selection Methods, Arkivoc 2002, IV, 45-49, http://www. arkat-usa. org/

[92] Z. Mihalić, N. Trinajstić, A Graph-Theoretical Approach to Structure-Property Relationships, J. Chem. Educ. 1992, 69, 701-712.

[93] J. von Knop, W. R. Müller, K. Szymanski, N. Trinajstić, Computer Generation of Certain Classes of Molecules, SKTH/Kemija u industriji, Zagreb, 1985.

[94] N. Trinajstić, S. Nikolić, J. von Knop, W. R. Müller, K. Szymanski, Computational Chemical Graph Theory: Characterization, Enumeration and Generation of Chemical Structures by Computer Methods, Simon \& Schuster/Horwood, Chichester, 1991. 
[95] J. von Knop, W. R. Müller, Ž. Jeričević, N. Trinajstić, Computer Enumeration and Generation of Trees and Rooted Trees, J. Chem. Inf. Comput. Sci. 1981, 21, 91-99.

[96] W. R. Müller, K. Szymanski, J. von Knop, S. Nikolić, N. Trinajstić, On the Enumeration and Generation of Polyhex Hydrocarbons, J. Comput. Chem. 1990, 11, 223-235.

[97] M. Randić, Compact Molecular Codes, J. Chem. Inf. Comput. Sci. 1986, 26, 136-148.

[98] M. Randić, Compact Codes. 2. Bicyclic Saturated Hydrocarbons, Croat. Chem. Acta 1986, 59, 327-343.

[99] M. Randić, S. Nikolić, N. Trinajstić, Compact Molecular Codes for Polycyclic Systems, J. Mol. Struct. (Theochem) 1988, 165, 213-228.

[100] S. Nikolić, N. Trinajstić, Compact Molecular Codes for Annulenes, Aza-annulenes, Annulenoannulenes, Aza-annulenoannulenes, Cyclazines and Azacyclazines, Croat. Chem. Acta 1990, 63, 155-170.

[101] J. von Knop, W. R. Müller, K. Szymanski, S. Nikolić, N. Trinajstić, Computer-Oriented Molecular Codes, in Computational Chemical Graph Theory (Ed.: D. H. Rouvray), Nova Sci. Publ., Commack, N. Y., 1990, pp. 9-32.

[102] M. Randić, S. Nikolić, N. Trinajstić, Compact Codes: On Nomenclature of Acyclic Chemical Compounds, J. Chem. Inf. Comput. Sci. 1995, 35, 357-365.

[103] M. L. Contreras, J. Alvarez, M. Riveros, G. Arias, R. Rozas, Exhaustive Generation of Organic Isomers. 6. Stereoisomers Having Isolated and Spiro Cycles and New Extended N-tuples, J. Chem. Inf. Comput. Sci. 2001, 41, 964-977.

[104] S. Davidson, Fast Generation of an Alkane-Series Dictionary Ordered by Side-Chain Complexity, J. Chem. Inf. Comput. Sci. 2002, 42, 147-156.

[105] J. August, H. W. Kroto, N. Trinajstić, Interstellar Polyynes and Related Species, Astrophys. Space Sci. 1986, 128, 411-419.

[106] J. von Knop, K. Szymanski, W. R. Müller, H. W. Kroto, N. Trinajstić, Computer Enumeration and Generation of Physical Trees, J. Comput. Chem. 1987, 8, 549-554.

[107] I. Lukovits, Isomer Generation: Syntactic Rules for Detection of Isomorphism, J. Chem. Inf. Comput. Sci. 1999, 39, 563-568.

[108] I. Lukovits, I. Gutman, On Morgan-Trees, Croat. Chem. Acta 2002, 75, 563-576; T. Došlić, Morgan Tress, Dyck Paths, Croat. Chem. Acta 2002, 75, 881-889.

[109] D. J. Klein, D. Babić, N. Trinajstić, Enumeration in Chemistry, in: Chemical Modelling: Applications and Theory (Ed.: A. Hinchliffe), The Royal Society of Chemistry, London, 2002, Vol. 2, pp. 56-95; D. Babić, D. J. Klein, J. von Knop, N. Trinajstić, Combinatorial Enumeration in Chemistry, in Chemical Modelling:
Applications and Theory (Ed.: A. Hinchliffe), The Royal Society of Chemistry, London, 2004, Vol. 3, pp. 126-170; A. Miličević, N. Trinajstić, Combinatorial Enumeration in Chemistry, in Chemical Modelling: Applications and Theory (Ed.: A. Hinchliffe), The Royal Society of Chemistry, London, The Royal Society of Chemistry, London, 2006, Vol. 4, pp. 405-469.

[110] M. Randić, N. Trinajstić, Semiempirical Calculation of Bond Lengths in Cyclopentadienyl Ligands, J. Chem. Phys. 1967, 46, 1469-1474.

[111] D. Bonchev, W. A. Seitz, The Concept of Complexity in Chemistry, in: Concepts in Chemistry - A Contemporary Challenge (Ed.: D. H. Rouvray), Wiley, New York, 1997, 353-381.

[112] R. B. Mallion, N. Trinajstić, Reciprocal Spanning-Tree Density: A New Index Characterising the Intricacy of (Poly)cyclic Molecular-Graph, MATCH - Commun. Math. Computer Chem. 2003, 48, 97-116.

[113] S. Nikolić, I. M. Tolić, N. Trinajstić, I. Baučić, On the Zagreb Indices as Complexity Indices, Croat. Chem. Acta 2000, 73, 909-921.

[114] S. Nikolić, N. Trinajstić, I. M. Tolić, Complexity of Molecules, J. Chem. Inf. Comput. Sci. 2000, 40, 920926.

[115] S. Nikolić, N. Trinajstić, I. M. Tolić, G. Rücker, C. Rücker, On Molecular Complexity Indices, in Complexity- Introduction and Fundamentals (Eds.: D. Bonchev, D. H. Rouvray), Taylor \& Francis, London, 2003, pp. 29-89.

[116] N. Trinajstić, The 70th Anniversary of CROATICA CHEMICA ACTA 1927-1997, Croat. Chem. Acta 1997, 59, I-IV.

[117] N. Trinajstić, Quantum Theory in Chemistry - Early Developments, Kem. ind. (Zagreb) 2001, 50, 427-429.

[118] N. Trinajstić, Quantum Theory in Chemistry, in: Hundred Years of Quantum Theory (Ed.: D. Tadić), Croatian Academy of Sciences and Arts, Zagreb, 2002, pp. 55-65.

[119] N. Trinajstić, Hoffmann, Roald (1937) - Primijenjena teorijska kemija (Applied Theoretical Chemistry), in Velikani naše Epohe (Great Men of Our Time) (Ed.: R. Vince), Hrvatski radio, Zagreb 1994, 317-322.

[120] N. Trinajstić, Roald Hoffmann - Scientist and Poet, Ref. 7, pp. 94-109.

[121] N. Trinajstić, Dopisivanje s profesorom Vladimirom Prelogom (Correspondence with Professor Vladimir Prelog), Kem. ind. (Zagreb) 1999, 48, 151-157.

[122] M. Randić, N. Trinajstić, Notes on Some Less Known Early Contributions to Chemical Graph Theory, Croat. Chem. Acta 1994,67, 1-35.

[123] L. Pogliani, M. Randić, N. Trinajstić, Much Ado about Nothing - An Introductory Inquiry about Zero, Int. J. Math. Educ. Sci. Technol. 1998, 29, 729-744. 
[124] L. Pogliani, M. Randić, N. Trinajstić, About One - An Inquiry About the Meaning and Uses of the Number One, Int. J. Math. Educ. Sci. Technol. 2000, 31, 811-824.

[125] N. Trinajstić, The Magic of the Number Five, Croat. Chem. Acta 1993, 66, 227-254.
[126] I. M. Tolić, N. Trinajstić, The Number Five in Biology, Period. Biol. 1998, 100, 259-265.

[127] L. Pogliani, M. Randić, N. Trinajstić, What Can Be Said About Number 13 Beyond the Fact That It Is a Prime Number?, Croat. Chem. Acta 2004, 77, 447-456. 


\section{Scientific papers}

1. N. Trinajstić and M. Randić

"Maximum Overlap Hybridisation in Methyl Substituted Cyclopropanes"

J. CHEM SOC., 5621-5624 (1965).

2. N. Trinajstić

"Molecular Orbital Calculations for [18]Annulene Trioxide"

CROAT. CHEM. ACTA 37, 307-311 (1965).

3. A. Hinchliffe, J. N. Murrell and N. Trinajstić

"Calculation on the Energy Levels of Alterant Hydrocarbon Anions"

TRANS. FARADAY SOC. 62, 1362-1369 (1966).

4. J. N. Murrell, J. G. Stamper and N. Trinajstić

"Localized Orbitals of Water"

J. CHEM. SOC. A, 1624-1627 (1966).

5. N. Trinajstić

"Molecular Orbital Calculations for Tetracene Monopositive Ion"

CROAT. CHEM. ACTA 38, 283-286 (1966).

6. N. Trinajstić

"Equivalent Orbitals of $\mathrm{NH}, \mathrm{NH}_{2}$ and $\mathrm{NH}_{3}$ "

CROAT. CHEM. ACTA 38, 287-291 (1966).

7. S. Carter, J. N. Murrell, E. J. Rosch, N. Trinajstić and P. A. H. Wyatt "The Kinetics of Unsymmetrical Quinone-Hydroquinone Redox Reactions"

J. CHEM. SOC. B, 477-484 (1967).

8. M. Randićand N. Trinajstić

"Semiempirical Calculation of Bond Lengths in Cyclopentadienyl Ligands"

J. CHEM. PHYS. 46, 1469-1474 (1967).

9. J. G. Stamper and N. Trinajstić

"Localized Orbitals for Some Simple Molecules"

J. CHEM. SOC. A, 782-784 (1967).

10. K. Blažević and N. Trinajstić

"A Discussion of the Absorption Spectra of Substituted 4-Pyridones and Their 4-Thio Analogues" CROAT. CHEM. ACTA 39, 25-28 (1967).

11. N. Trinajstić and A. Hinchliffe

"Molecular Orbital Calculations for the Three Isomeric Thiophthenes"

CROAT. CHEM. ACTA 39, 119-124 (1967).

12. N. Stojanac and N. Trinajstić

"Elektronenspektren einiger Thioamide und Ihrer S- und N-Derivate"

MONAT. CHEM. 98, 2263-2271 (1967). 
13. N. Trinajstić

"Heterocyclische Sauerstoff- und Schwefelanaloge des [18]Annulens"

MONAT. CHEM. 98, 2077-2081 (1967).

14. N. Trinajstić

"Equivalent Orbitals for $\mathrm{C}_{2} \mathrm{H}_{2}, \mathrm{C}_{2} \mathrm{H}_{4}$, and $\mathrm{C}_{2} \mathrm{H}_{6}$ "

Z. PHYS. CHEM. (Leipzig) 236, 369-371 (1967).

15. N. Trinajstić and Z. Majerski

"Reactivity of Thiophthenes: A Theoretical Study"

Z. NATURFORSCH. 22a, 1475-1476 (1967).

16. N. Trinajstić and A. Hinchliffe

"Molecular Orbital Calculations for the Benzothiophenes and Naphthothiophenes"

Z. PHYS. CHEM. (Frankfurt) 59, 271-281 (1968).

17. L. Klasinc, Z. Majerski and N. Trinajstić

"Reactivity Indices for Benzotropones"

Z. NATURFORSCH. 23a, 192-194 (1968).

18. N. Trinajstić

"Calculation of Carbon-Sulphur Bond Lenghts"

TETRAHEDRON LETT., 1529-1532 (1968).

19. J. N. Herak and N. Trinajstić

"Free Valence Indices of Carbon in Heterocyclic Compounds"

THEORET. CHIM. ACTA 9, 333-335 (1968).

20. L. Klasinc, Z. Majerski and N. Trinajstić

"Molecular Orbital Calculations for Some Furotropones"

Z. PHYS. CHEM. (Leipzig) 239, 262-267 (1968).

21. A. Hinchliffe and N. Trinajstić

"Calculation of Proton Coupling Constants for Dibenzothiophene Radical Anion"

THEORET. CHIM. ACTA 10, 458-460 (1968).

22. N. Trinajstić and A. Hinchliffe

"Molecular Orbital Calculation for Some Bithiophenes and Bifurans"

CROAT. CHEM. ACTA 40, 163-169 (1968).

23. A. Hinchliffe and N. Trinajstić

"Electronic Properties of Conjugated Ions"

THEORET. CHIM. ACTA 11, 271-273 (1968).

24. A. Kornhauser, J. N. Herak and N. Trinajstić

"Mechanism of Photosensitized Dimerization of Pyrimidines"

CHEM. COMM., 1108-1109 (1968).

25. T. Živković and N. Trinajstić

"Novel Expression for Electronic Density Distribution Calculations"

CHEM. PHYS. LETT. 2, 369-370 (1968). 
26. E. Gey, Z. B. Maksić and N. Trinajstić

"Localized Molecular Orbitals in Simple Polyatomic Molecules"

J. MOL. STRUCT. 3, 21-26 (1969).

27. T. Živković and N. Trinajstić

"Calculation of the Bond Lengths in Sulphur-Containing Heterocyclic Systems"

CAN. J. CHEM. 47, 697-699 (1969).

28. N. Trinajstić and R. J. Wratten

"A Semiempirical Investigation of Annulenes"

J. MOL. STRUCT. 3, 395-402 (1969).

29. N. Trinajstić

"Reactivity of Maleic Anhydride With Polycyclic Hydrocarbons with 'Open' Ends"

CROAT. CHEM. ACTA 41, 47-48 (1969).

30. M. J. S. Dewar and N. Trinajstić

"Theoretical Study of Cyclazines"

J. CHEM. SOC. A, 1754-1755 (1969).

31. M. J. S. Dewar and N. Trinajstić

"Aromaticity in Polycyclic Annulenes"

TETRAHEDRON LETT., 2129-2132 (1969).

32. M. J. S. Dewar and N. Trinajstić

"Ground States of Conjugated Molecules. XIV. Redox Potentials of Quinones"

TETRAHEDRON 25, 4529-4534 (1969).

33. M. J. S. Dewar, A. J. Harget and N. Trinajstić

"Ground States of Conjugated Molecules. XV. Bond Localization and Resonance Energies in Compounds Containing Nitrogen or Oxygen"

J. AMER. CHEM. SOC. 91, 6321-6325 (1969).

34. M. J. S. Dewar and N. Trinajstić

"A SCF MO Treatment of Some Tropone Derivatives

CROAT. CHEM. ACTA 42, 1-12 (1970).

35. M. J. S. Dewar and N. Trinajstić

"Ground States of Conjugated Molecules. XX. SCF MO Treatment of Compounds Containing Bivalent Sulphur"

J. AMER. CHEM. SOC. 92, 1453-1459 (1970).

36. M. J. S. Dewar and N. Trinajstić

"Quantum Chemical Data. I. SCF Molecular Orbitals for Benzenoid Hydrocarbons"

COLL. CZECH. CHEM. COMM. 35, 3137-3189 (1970).

37. M. J. S. Dewar and N. Trinajstić

"Quantum Chemical Data. II. SCF Molecular Orbitals for Non-Benzenoid Hydrocarbons"

COLL. CZECH. CHEM. COMM. 35, 3484-3518 (1970). 
38. M. J. S. Dewar and N. Trinajstić

"Ground States of Conjugated Molecules. XVIII. Azepines and Oxepines"

TETRAHEDRON 26, 4269-4276 (1970).

39. M. J. S. Dewar and N. Trinajstić

"Resonance Energies of Some Compounds Containing Nitrogen or Oxygen"

THEORET. CHIM. ACTA 17, 235-238 (1970).

40. M. J. S. Dewar, A. J. Harget, N. Trinajstić and S. D. Worley

"Ground States of Conjugated Molecules. XXI. Benzofurans and Benzopyrroles"

TETRAHEDRON 26, 4505-4516 (1970).

41. Z. Majerski and N. Trinajstić

"Tautomerism of Phenols - Theoretical Study"

BULL. CHEM. SOC. JAPAN 43, 2648-2649 (1970).

42. M. J. S. Dewar and N. Trinajstić

"Triplet States of Aromatic Hydrocarbons"

CHEM. COMM., 646-647 (1970).

43. N. Bodor and N. Trinajstić

"Valence-Shell MO Calculations for Formamide and Related Compounds"

REV. ROUM. CHIM. 15, 1807-1811 (1970).

44. M. J. S. Dewar, J. A. Hashmall and N. Trinajstić

"Ground States of Conjugated Molecules. XXII. Polarographic Reduction Potentials of Hydrocarbons"

J. AMER. CHEM. SOC. 92, 5555-5559 (1970).

45. M. J. S. Dewar and N. Trinajstić

"Semiempirical SCF MO Treatment of Excited States of Aromatic Compounds"

J. CHEM. SOC. A, 1220-1237 (1971).

46. M. J. S. Dewar, D. H. Lo, D. B. Patterson, N. Trinajstić and G. E. Peterson

"MINDO/2 Calculations of Nuclear Quadrupole Coupling Constants of Chlorobenzenes"

J. CHEM. SOC. CHEM. COMM., 238-239 (1971).

47. M. J. S. Dewar, M. C. Kohn and N. Trinajstić

"Cyclobutadiene and Diphenylcyclobutadiene"

J. AMER. CHEM. SOC. 93, 3437-3440 (1971).

48. N. Trinajstić

"An SCF MO Treatment of Tropone Radical Anion"

BULL. CHEM. SOC. JAPAN 44, 3208-3209 (1971).

49. N. Trinajstić

"Eight $\pi$-Electron Systems"

J. MOL. STRUCT. 8, 236-239 (1971). 
50. N. Bodor, M. Farkas and N. Trinajstić

"SCF MO Calculations for 1,3-Thiazole and 2-Phenyl-1,3-Thiazole and

Rotational Barriers in 2-Phenyl-1,3-Thiazole and Its Protonated Form"

CROAT. CHEM. ACTA 43, 107-111 (1971).

51. N. Bodor, E. Pop and N. Trinajstić

"Valence-Shell and $\pi$-Electron SCF MO Calculations for the Isomerism of the 21-Benzylidene20-Oxo-Pregnane Derivatives"

REV. ROUM. CHIM. 16, 1427-1433 (1971).

52. N. Bodor, I. Schwartz and N. Trinajstić

"SCF MO Study of the Tautomerism of Anilino-Thiazole and Related Compounds"

Z. NATURFORSCH. 26b, 400-402 (1971).

53. N. Trinajstić

"The Spin Density Distribution in the Benzyl Radical"

CHEM. PHYS. LETT. 10, 172-173 (1971).

54. L. Klasinc and N. Trinajstić

"Theoretical Study of Isocondensed Thienopyrroles"

TETRAHEDRON 27, 4045-4052 (1971).

55. N. Trinajstić

"Molecular Orbital Calculations of Aromatic Stabilization of Polycyclic Conjugated Molecules"

RECORD CHEM. PROGRESS 32, 85-97 (1971).

56. Z. Majerski and N. Trinajstić

"Tetra-cycloalkanes. I. "

CROAT. CHEM. ACTA 43, 199-203 (1971).

57. N. Zambelli and N. Trinajstić

"Theoretical Study of Furotropones"

Z. NATURFORSCH. 26b, 1007-1010 (1971).

58. N. Trinajstić

"The Spin Density Distribution in the Hydrocarbon Radical Ions"

SPECTROSCOPY LETT. 4, 85-89 (1971).

59. M. Milun, Ž. Sobotka and N. Trinajstić

"Hückel Molecular Orbital Calculations of Index of Aromatic Stabilization of Polycyclic Conjugated Molecules"

J. ORG. CHEM. 37, 139-141 (1972).

60. I. Gutman, M. Milun and N. Trinajstić

"Hückel Molecular Orbital Calculations of Aromatic Stabilization of Annulenes"

CROAT. CHEM. ACTA. 44, 207-213 (1972).

61. V. Galasso and N. Trinajstić

"Conformational Analysis and Electronic Structure of Phenylthiazoles and Teir Protonated Forms"

TETRAHEDRON 28, 2799-2804 (1972). 
62. L. Klasinc, E. Pop, N. Trinajstić and J. V. Knop

"Theoretical Studies of Positional Isomers Obtained by Annelation of Benzene and 5Membered Ring Heterocyclics Containing Nitrogen, Oxygen, or Sulphur"

TETRAHEDRON 28, 3465-3474 (1972).

63. A. Graovac, I. Gutman, N. Trinajstić and T. ŽivkoviĆ

"Graph Theory and Molecular Orbitals. Application of Sachs Theorem"

THEORET. CHIM. ACTA 26, 67-78 (1972).

64. I. Gutman, N. Trinajstić and T. Živković

"Comments on the PMO Method"

CHEM. PHYS. LETT. 14, 342-345 (1972).

65. V. Galasso and N. Trinajstić

"A Quantum-Mechanical Study on the Stereochemistry of the Isomeric Bipyrroles, Bifurans, Bithiophenes, Thienylfurans, Biselenophenes"

TETRAHEDRON 28, 4419-4429 (1972).

66. D. Cvetković, I. Gutman and N. Trinajstić

"Graph Theory and Molecular Orbitals. II"

CROAT. CHEM. ACTA. 44, 365-374 (1972).

67. I. Gutman, N. Trinajstić and T. Živković

"Theoretical Studies on Radialenes and Related Molecules"

CROAT. CHEM. ACTA 44, 501-505 (1972).

68. D. Cvetković, I. Gutman and N. Trinajstić

"Kekulé Structures and Topology"

CHEM. PHYS. LETT. 16, 614-616 (1972).

69. I. Gutman and N. Trinajstić

"Graph Theory and Molecular Orbitals. III. Total $\pi$-Electron Energy

of Alternant Hydrocarbons"

CHEM. PHYS. LETT. 17, 535-538 (1972).

70. I. Gutman, M. Milun and N. Trinajstić

"Comments on the Paper: 'Properties of the Latent Roots of a Matrix, Estimation of $\pi$-Electron

Energies' by B. J. McClelland"

J. CHEM. PHYS. 59, 2772-2774 (1973).

71. L. Klasinc, E. Pop and N. Trinajstić

"Theoretical Study of Isomeric Thienylfurans"

REV. ROUM. CHIM. 18, 89-98 (1973).

72. A. Graovac, I. Gutman, M. Randić and N. Trinajstić

"Kekulé Index for Valence Bond Structures of Conjugated Polycyclic Systems"

J. AMER. CHEM. SOC. 95, 6267-6273 (1973).

73. E. Pop, L. Klasinc and N. Trinajstić

"Theoretical Studies of Some Furocoumarin Isomers"

REV. ROUM. CHIM. 18, 1249-1257 (1973). 
74. I. Gutman and N. Trinajstić

"Graph Theory and Molecular Orbitals"

TOPICS CURR. CHEM. 42, 49-93 (1973).

75. I. Gutman and N. Trinajstić

"Graph Theory and Molecular Orbitals. IV. Further Application of Sachs Formula"

CROAT. CHEM. ACTA 45, 423-429 (1973).

76. V. Galasso, M. Milun and N. Trinajstić

"Thienopyrroles. Theoretical Studies on the Preferred Conformation and Electronic Structure"

Z. NATURFORSCH. 28b, 464-467 (1973).

77. M. Milun and N. Trinajstić

"Cyclobutadiene, Benzocyclobutadiene, and Biphenylene"

Z. NATURFORSCH. 28b, 478-482 (1973)

78. I. Gutman and N. Trinajstić

"Graph Theory and Molecular Orbitals. V. The Loop Rule"

CHEM. PHYS. LETT. 20, 257-260 (1973).

79. I. Gutman, N. Trinajstić and T. Živković

"Graph Theory Molecular Orbitals. VI. A Discussion of Non-Alternant Hydrocarbons"

TETRAHEDRON 29, 3449-3454 (1973).

80. M. Milun and N. Trinajstić

"Theoretical Studies on the Electronic Spectra of Isomeric Bifurans, Bipyrroles, Bithiophenes, Thienylfurans, Thienylpyrroles, and Furylpyrroles"

SPECTROSCOPY LETT. 6, 329-346 (1973).

81. V. Galasso and N. Trinajstić

"Application of the INDO-MO Method to the Calculation of Hyperfine Coupling Constants of Sulphur-Containing Radicals. I. Thiophen Radicals"

J. CHIM. PHYS. 70, 1489-1492 (1973).

82. I. Gutman and N. Trinajstić

"A Graph-Theoretical Classification of Conjugated Hydrocarbons"

NATURWISS. 60, 475 (1973).

83. J. V. Knop, N. Trinajstić, I. Gutman and L. Klasinc

"A Graph-Theoretical Study of Positional Isomers"

NATURWISS. 60, 475-476 (1973).

84. I. Gutman and N. Trinajstić

"Graph Theory and Molecular Orbitals. VIII. Kekulé Structures and Permutations"

CROAT. CHEM. ACTA 45, 539-545 (1973).

85. I. Gutman, M. Milun and N. Trinajstić

"On the Dewar Definition of Resonance Energy"

CHEM. PHYS. LETT. 23, 284-286 (1973). 
86. D. Cvetković, I. Gutman and N. Trinajstić

"Graph Theory and Molecular Orbitals. VII. The Role of Resonance Structures"

J. CHEM. PHYS. 61, 2700-2706 (1974).

87. D. Cvetković, I. Gutman and N. Trinajstić

"Graph Theory and Molecular Orbitals. IX. On the Stability of Cata-Condensed Hydrocarbons" THEORET. CHIM. ACTA 34, 129-136 (1974).

88. I. Gutman, J. V. Knop and N. Trinajstić

"A Graph-Theoretical Analysis of the HOMO-LUMO Separation in Conjugated Hydrocarbons"

Z. NATURFORSCH. 29b, 80-82 (1974).

89. J. Koller, A. Ažman and N. Trinajstić

"Some Ab Initio Calculations on Indole, Isoindole, Benzofuran and Isobenzofuran"

Z. NATURFORSCH. 29a, 624-632 (1974).

90. J. V. Knop, N. Trinajstić and T. Živković

"A Graphical Study of Positional Isomers Containing Bivalent Sulphur"

COLL. CZECH. CHEM. COMM. 39, 2431-2448 (1974).

91. R. B. Mallion, A. J. Schwenk and N. Trinajstić

"A Graphical Study of Heteroconjugated Molecules"

CROAT. CHEM. ACTA 46, 171-182 (1974).

92. R. B. Mallion, N. Trinajstić and A. J. Schwenk

"Graph Theory in Chemistry. Generalization of Sachs' Formula"

Z. NATURFORSCH. 29a, 1481-1484 (1974).

93. I. Gutman and N. Trinajstić

"Violation of the Dewar-Longuet-Higgins Conjecture"

Z. NATURFORSCH. 29a, 1238 (1974).

94. D. Cvetković, I. Gutman and N. Trinajstić

"Conjugated Molecules Having Integral Spectra"

CHEM. PHYS. LETT. 29, 65-68 (1974).

95. I. Gutman and N. Trinajstić

"Graph Theory and Molecular Orbitals. XIII. On the Stability of Annelated Tropylium Cations" CROAT. CHEM. ACTA 46, 243-248 (1974)

96. I. Gutman, N. Trinajstić and C. F. Wilcox, Jr.

"Graph Theory and Molecular Orbitals. X. The Number of Kekulé Structures and the Thermodynamc Stability of Conjugated Systems"

TETRAHEDRON 31, 143-146 (1975).

97. C. F. Wilcox, Jr., I. Gutman and N. Trinajstić

"Graph Theory and Molecular Orbital. XI. Aromatic Substitution"

TETRAHEDRON 31, 147-152 (1975). 
98. I. Gutman, B. Ruščić, N. Trinajstić and C. F. Wilcox, Jr.

"Graph Theory and Molecular Orbitals. XII. Acyclic Polyenes"

J. CHEM. PHYS. 62, 3399-3405 (1975).

99. I. Gutman and N. Trinajstić

"On the Parity of Kekulé Structures"

CROAT. CHEM. ACTA 47, 35-39 (1975).

100. D. Cvetković, I. Gutman and N. Trinajstić

"Graphical Studies on the Relations Between the Structure and Reactivity of Conjugated Systems: The Role of Non-Bonding Molecular Orbitals"

J. MOL. STRUCT. 28, 289-303 (1975).

101. T. Živković, N. Trinajstić and M. Randić

"On Conjugated Molecules With Identical Topological Spectra"

MOL. PHYS. 30, 517-533 (1975).

102. A. Graovac and N. Trinajstić

"Möbius Molecules and Graphs"

CROAT. CHEM. ACTA 47, 95-104 (1975).

103. A. Graovac, I. Gutman and N. Trinajstić

"On the Coulson Integral Formula for Total $\pi$-Electron Energy"

CHEM. PHYS. LETT. 35, 555-557 (1975).

104. N. Trinajstić and I. Gutman

"Some Aspects of Graph Spectral Theory of Conjugated Molecules"

MATH. CHEM. (Mülheim/Ruhr) 1, 71-82 (1975).

105. A. Graovac and N. Trinajstić

"Graphs in Chemistry"

MATH. CHEM. (Mülheim/Ruhr) 1, 159-170 (1975).

106. I. Gutman, M. Milun and N. Trinajstić

"Topological Definition of Resonance Energy"

MATH. CHEM. (Mülheim/Ruhr) 1, 171-175 (1975).

107. J. V. Knop, N. Trinajstić and T. Živković

"Graphical Study of Positional Isomers"

MATH. CHEM. (Mülheim/Ruhr) 1, 177-181 (1975)

108. I. Gutman and N. Trinajstić

"Graph Spectral Theory of Conjugated Molecules"

CROAT. CHEM. ACTA 47, 507-533 (1975).

109. A. Graovac, O. E. Polansky, N. Trinajstić and N. Tyutyulkov

"Graph Theory in Chemistry. II. Graph-Theoretical Description of Heteroconjugated Molecules"

Z. NATURFORSCH. 30a, 1696-1699 (1975).

110 A. Graovac and N. Trinajstić

"Graphical Description of Möbius Molecules"

J. MOL. STRUCT. 30, 416-420 (1976) 
111. A. Graovac, I. Gutman and N. Trinajstić

"A Linear Relationship Between Total $\pi$-Electron Energy and the Characteristic Polynomial" CHEM. PHYS. LETT. 37, 471-474 (1976).

112. J. V. Knop, A. Sabljić and N. Trinajstić

"Topological Studies of Fused Tricyclic and Tetracyclic Molecules Having Planar Conjugated Perimeter"

REV. ROUM. CHIM. 21, 749-755 (1976).

113. M. Randić, N. Trinajstić and T. Živković

"Molecular Graphs Having Identical Spectra"

J. CHEM. SOC. FARADAY TRANS. II, 244-256 (1976).

114. I. Gutman and N. Trinajstić

"Graph Theory and Molecular Orbitals. XIV. On Topological Definition of Resonance Energy" ACTA CHIM. ACAD. SCI. HUNGARICAE 91, 203-209 (1976).

115. I. Gutman and N. Trinajstić

"Graph Theory and Molecular Orbitals. XV. The Hückel Rule"

J. CHEM. PHYS. 64, 4921-4925 (1976).

116. I. Gutman and N. Trinajstić

"Graph Theory and Molecular Orbitals. XVI. On $\pi$-Electron Charge Distribution"

CROAT. CHEM. ACTA 48, 19-24 (1976)

117. I. Gutman and N. Trinajstić

"Graph Theory and Molecular Orbitals. XVII. On the Self-Polarizability of the Atom"

J. CHEM. PHYS. 65, 3796-3797 (1976).

118. I. Gutman, M. Milun and N. Trinajstić

"Graph Theory and Molecular Orbitals. XVIII. On Topological Resonance Energy"

CROAT. CHEM. ACTA 48, 87-95 (1976).

119. A. Sabljić, N. Trinajstić, J. V. Knop, J. Koller and A. Ažman

"Ab Initio Study of Methyl Substituted Allyl Cations"

J. MOL. STRUCT. 33, 145-150 (1976).

120. J. V. Knop, M. Milun and N. Trinajstić

"On Aromatic Stability of Oxygen-, Imino-, and Sulphur-Bridged [18]Annulenes"

J. HETEROCYCL. CHEM. 13, 505-508 (1976).

121. I. Gutman and N. Trinajstić

"On the Extension of the Hückel Rule to Polycyclic Non-Alternant

Conjugated Hydrocarbons"

CAN. J. CHEM. 54, 1789-1794 (1976).

122. I. Gutman and N. Trinajstić

"Simple Topological Formula for Dewar Resonance Energies of Benzenoid Molecules" CROAT. CHEM. ACTA 48, 297-299 (1976). 
123. A. Graovac, I. Gutman, M. Randić and N. Trinajstić

"On Structural Features Characterizing Conductivity in Polymeric Conjugated Hydrocarbons" COLLOID POLYMER SCI. 255, 480-487 (1977).

124. I. Gutman, M. Milun N. Trinajstić

"Graph Theory and Molecular Orbitals. XIX. Non-Parametric Resonance Energies of Arbitrary Conjugated Systems"

J. AMER. CHEM. SOC. 99, 1692-1704 (1977).

125. T. Živković, N. Trinajstić and M. Randić

"On Topological Spectra of Composite Molecular Systems"

CROAT. CHEM. ACTA 49, 89-100 (1977).

126. I. Gutman and N. Trinajstić

"Applications of the Cauchy Inequalities in Simple Molecular Orbital Theory"

J. CHEM. SOC. FARADAY TRANS. II, 435-437 (1977).

127. I. Gutman and N. Trinajstić

"Factors Contributing to the Stability of Conjugated Heterocycles Containing a Single Heteroatom" CHEM. PHYS. LETT. 46, 591-593 (1977).

128. N. Trinajstić

"New Developments in Hückel Theory"

INT. J. QUANTUM CHEM. S 11, 469-477 (1977).

129. D. Bonchev and N. Trinajstić

"Information Theory, Distance Matrix, and Molecular Branching"

J. CHEM. PHYS. 67, 4517-4533 (1977).

130. M. Milun and N. Trinajstić

"Resonance Energy as a Criterion for Reactivities of Conjugated Hydrocarbons"

CROAT. CHEM. ACTA 49, 101-105 (1977).

131. M. Milun and N. Trinajstić

"On Aromatic Stability of Positional Isomers Consisting of Bicyclic Systems Composed Entirely of Five-Membered Heterocycles"

CROAT. CHEM. ACTA 49, 107-113 (1977).

132. I. Gutman, M. Milun and N. Trinajstić

"Topological Resonance Energies of Annulenes"

CROAT. CHEM ACTA 49, 441-452 (1977).

133. N. Trinajstić

"Computing the Characteristic Polynomial of a Conjugated System Using the Sachs Theorem" CROAT. CHEM. ACTA 49, 593-633 (1977).

134. A. Graovac, I. Gutman and N. Trinajstić

"Graph-Theoretical Study of Conjugated Hydrocarbons. Total $\pi$-Electron Energies and Their Differences"

INT. J. QUANTUM CHEM. 12 (Suppl 1), 153-155 (1977). 
135. J. V. Knop, N. Trinajstić, M. Milun and S. Pejaković

"Conformational Analysis and Electronic Structure of Thienylpyridines"

REV. ROUM. CHIM. 23, 103-110 (1978).

136. I. Gutman, M. Randić and N. Trinajstić

"Kekulé Structures and Topology. III. On Inseparability of Kekulé Structures"

REV. ROUM. CHIM. 23, 383-395 (1978).

137. A. Graovac, I. Gutman, M. Randić and N. Trinajstić

"Kekulé Index for Valence Bond Structures of Conjugated Systems Containing Cyclobutadiene" COLL. CZECH. CHEM. COMM. 43, 1375-1392 (1978).

138. A. Sabljić and N. Trinajstić

"Theoretical Study of Azacyclazines"

J. MOL. STRUCT. 49, 415-420 (1978).

139. A. Sabljić and N. Trinajstić

"Theoretical Study of Triafulvene, Fulvene, Heptafulvene, and Their O- and N-Heteroanalogs" CROAT. CHEM. ACTA 51, 249-257 (1978).

140. I. Gutman, S. Bosanac and N. Trinajstić

"Graph Theory and Molecular Orbitals. XX. Local and Long Range Contributions to Bond Order" CROAT. CHEM. ACTA 51, 293-298 (1978).

141. D. Bonchev and N. Trinajstić

"On Topological Characterization of Molecular Branching"

INT. J. QUANTUM CHEM. S 12, 293-303 (1978).

142. P. Ilić, B. Jerman-Blažič-Džonova, B. Mohar and N. Trinajstić

"On Normalization of Topological Resonance Energy"

CROAT. CHEM. ACTA. 52, 35-42 (1979).

143. D. Bonchev, Ov. Mekenyan, G. Protić and N. Trinajstić

"Application of Topological Indices to Gas Chromatographic Data: Calculation of the Retention Indices of Isomeric Alkylbenzenes"

J. CHROMATOGR. 176, 149-156 (1979).

144. M. Hannoun, N. Blažević, D. Kolbach, A. Sabljić, N. Trinajstić, A. Sega,

A. Lisini, F. Kajfež and V. Šunjić

"Friedel-Crafts Acylation of 3-Carboxymethylbenzo[b]thiophenes: LIS-NMR and HMO Study of Regioselectivity"

J. HETEROCYCL. CHEM. 16, 1029-1034 (1979).

145. D. Bonchev, J. V. Knop and N. Trinajstić

"Mathematical Models of Branching"

MATH. CHEM. (Mülheim/Ruhr) 6, 21-47 (1979).

146. Ov. Mekenyan, D. Bonchev and N. Trinajstić

"Topological Rules for Spirocompounds"

MATH. CHEM. (Mülheim/Ruhr) 6, 93-115 (1979). 
147. L. Klasinc, B. Ruščić, A. Sabljić and N. Trinajstić

"Application of Photoelectron Spectroscopy to Biologically Active Molecules and Their Constituent Parts. VI. Opiate Narcotics"

J. AMER. CHEM. SOC. 101, 7477-7482 (1979).

148. L. J. Schaad, B. A. Hess, Jr., J. B. . Nation, N. Trinajstić and I. Gutman

"On the Reference Structure for the Resonance Energy of Aromatic Hydrocarbons"

CROAT. CHEM. ACTA 52, 233-248 (1979).

149. D. Bonchev, Ov. Mekenyan, J. V. Knop and N. Trinajstić

"On Characterization of Monocyclic Structures"

CROAT. CHEM. ACTA 52, 361-367 (1979).

150. D. Bonchev, G. Lickomannov and N. Trinajstić

"Information Theory Analysis of the Nodal Properties of $\pi$-Molecular Orbitals"

ACTA CHIM. ACAD. SCI. HUNGARICAE 102, 321-332 (1979).

151. B. M. Gimarc and N. Trinajstić

"Aromatic Inorganic Rings"

PURE APPL. CHEM. 52, 1443-1458 (1980).

152. P. Ilić and N. Trinajstić

"Topological Resonance Energy Approach to Homoaromaticity"

PURE APPL. CHEM. 52, 1495-1508 (1980).

153. P. Ilić and N. Trinajstić

"Topological Resonance Energies of Conjugated Ions, Radicals and Ion-Radicals"

J. ORG. CHEM. 45, 1738-1748 (1980).

154. P. Ilić, B. Sinković and N. Trinajstić

"Topological Resonance Energies of Conjugated Structures"

ISRAEL J. CHEM. 20, 258-269 (1980).

155. D. Bonchev, Ov. Mekenyan and N. Trinajstić

"Topological Characterization of Cyclic Structures"

INT. J. QUANTUM CHEM. 17, 845-893 (1980).

156. K. Tabaković, I. Tabaković, M. Trkovnik, A. Jurić and N. Trinajstić

"Studies on Novel Heterocyclic Ring Systems. Reaction of 4-Hydroxylcoumarin with o-Aminobenzaldehyde and 2-Mercaptoaniline"

J. HETEROCYCL. CHEM. 17, 801-803 (1980).

157. Ž. Jeričević, A. Sabljić and N. Trinajstić

"Spin Labels in Membranes: A Simple MO Study of Some Methyl Substituted Polyene Radicals"

INT. J. BIOL. MACROMOL 2, 266-267 (1980).

158. A. Graovac, N. Trinajstić and M. Randić

"Graph-Theoretical Search for Benzenoid Polymers with Zero Energy Gap"

CROAT. CHEM. ACTA 53, 571-579 (1980). 
159. P. Ilić, A. Jurić and N. Trinajstić

"On Topological Resonance Energy of Coumarin and Its Derivatives"

CROAT. CHEM. ACTA 53, 587-590 (1980).

160. P. Ilić and N. Trinajstić

"On the Topological Resonance Energy of Porphins and Related Structures"

CROAT. CHEM. ACTA 53, 591-599 (1980).

161. O. Mekenyan, D. Bonchev and N. Trinajstić

"Chemical Graph Theory: Modeling of Thermodynamic Properties of Molecules"

INT. J. QUANTUM CHEM. 18, 369-380 (1980).

162. J. V. Knop and N. Trinajstić

"Chemical Graph Theory. II. On the Graph Theoretical Polynomials of Conjugated Structures"

INT. J. QUANTUM CHEM.; QUANTUM CHEM. SYMP. 14, 503-520 (1980).

163. L. Klasinc, N. Trinajstić and J. V. Knop

"Application of Photoelectron Spectroscopy to Biologically Active Molecules and Their Constituent Parts. VIII. Thalidomide"

INT. J. QUANTUM CHEM.; QUANTUM BIOL. SYMP. 7, 403-409 (1980).

164. S. S. D'Amato, B. M. Gimarc and N. Trinajstić

"Isospectral and Subspectral Molecules"

CROAT. CHEM. ACTA 54, 1-52 (1981).

165. A. Graovac, D. Kasum and N. Trinajstić

"On Acyclic Polynomials of [N]-Heteroannulenes"

CROAT. CHEM. ACTA 54, 91-95 (1981).

166. V. Galasso, L. Klasinc, A. Sabljić, N. Trinajstić, G. C. Pappalardo, and W. Steglich

"Conformation and Photoelectron Spectra of 2-(2-Furyl)pyrrole and 2-(2-Thienyl)pyrrole"

J. CHEM. SOC. PERKIN TRANS. II, 127-131 (1981).

167. D. Bonchev, Ov. Mekenyan and N. Trinajstić

"Isomer Discrimination by Topological Information Approach"

J. COMPUT. CHEM. 2, 127-148 (1981).

168. J. V. Knop, W. R. Müller, Ž. Jeričević and N. Trinajstić

"Computer Enumeration and Generation of Trees and Rooted Trees"

J. CHEM. INF. COMPUT. SCI. 21, 91-99 (1981).

169. O. Mekenyan, D. Bonchev and N. Trinajstić

"Algebraic Characterization of Bridged Polycyclic Compounds"

INT. J. QUANTUM CHEM. 19, 929-955 (1981).

170. A. Sabljić, N. Trinajstić and D. Maysinger

"Molecular Connectivity and Biological Activity in a Series of Isatin Derivatives"

ACTA PHARM. JUGOSL. 31, 71-76 (1981). 
171. Ov. Mekenyan, D. Bonchev and N. Trinajstić

"A Topological Characterization of Cyclic Structures with Acyclic Branches"

MATH. CHEM. (Mülheim/Ruhr) 11, 145-168 (1981).

172. A. Sabljić and N. Trinajstić

"Aromatic Stability of Bridged Annulenes"

J. ORG. CHEM. 46, 3457-3461 (1981).

173. M. Randić, B. Ruščić and N. Trinajstić

"Herndon's Structure Resonance Theory. On the Valence Structure Count for Conjugated Radical Cations"

CROAT. CHEM. ACTA 54, 295-308 (1981).

174. T. Živković, N. Trinajstić and M. Randić

"On Additivity of Heats of Atomization of Benzenoid Hydrocarbons"

CROAT. CHEM. ACTA 54, 309-320 (1981).

175. D. Kasum, N. Trinajstić and I. Gutman

"Chemical Graph Theory. III. On the Permanental Polynomial"

CROAT. CHEM. ACTA 54, 321-328 (1981).

176. A. Sabljić and N. Trinajstić

"Quantitative Structure-Activity Relationships: The Role of Topological Indices"

ACTA PHARM. JUGOSL. 31, 189-214 (1981).

177. B. Mohar and N. Trinajstić

"On Computation of the Topological Resonance Energy"

J. COMPUT. CHEM. 3, 28-36 (1982).

178. B. M. Gimarc and N. Trinajstić

"Inorganic Aromatic Rings: The $\pi$-Electronic Structure of $\mathrm{B}_{6} \mathrm{~S}_{16}$ "

INORG. CHEM. 21, 21-25 (1982).

179. P. Ilić, B. Mohar, J. V. Knop, A. Jurić and N. Trinajstić

"The Topology and the Aromaticity of Coumarins"

J. HETEROCYCL. CHEM. 19, 625-631 (1982).

180. B. Džonova-Jerman-Blažič and N. Trinajstić

"Computer-Aided Enumeration and Generation of the Kekulé Structures in Conjugated Hydrocarbons"

COMPUT. CHEM. 6, 121-132 (1982).

181. B. Džonova-Jerman-Blažič and N. Trinajstić

"Applications of Reduced Graph Model to the Enumeration of Kekulé structures and Conjugated Circuits of Benzenoid Hydrocarbons"

CROAT. CHEM. ACTA 55, 347-369 (1982).

182. D. Bonchev and N. Trinajstić

"Chemical Information Theory: Structural Aspects"

INT. J. QUANTUM CHEM.; QUANTUM CHEM. SYMP. 16, 463-480 (1982). 
183. M. Randić and N. Trinajstić

"On Isomeric Variations in Decanes"

MATH. CHEM. (Mülheim/Ruhr) 13, 271-290 (1982).

184. Ž. Trgovčević, D. Petranović, E. Salaj-Šmic, M. Petranović, N. Trinajstić, and Ž. Jeričević "DNA Replication Past Pyrimidine Dimers in t he Absence of Repair"

MUTATION RES.- DNA REPAIR REPORTS 112, 17-22 (1983).

185. N. Trinajstić, Ž. Jeričević, J. V. Knop, W. R. Müller and K. Szymanski

"Computer Generation of Isomeric Structures"

PURE APPL. CHEM. 55, 379-390 (1983).

186. J. V. Knop, K. Szymanski, Ž. Jeričević and N. Trinajstić

"Computer Generation and Identification of Carcinogenic Bay Regions in Benzenoid Hydrocarbons"

INT. J. QUANTUM CHEM. 23, 713-722 (1983).

187. L. Klasinc, B. Ruščić, A. Sabljić and N. Trinajstić

"Application of Photoelectron Spectroscopy to Biologically Active Molecules and Their Constituent Parts. IX. 1,4-Benzodiazepin-2-ones"

INT. J. QUANTUM CHEM. 23, 1667-1676 (1983).

188. J. V. Knop, K. Szymanski, Ž. Jeričević and N. Trinajstić

"Computer Enumeration and Generation of Benzenoid Hydrocarbons and Identification of Bay Regions"

J. COMPUT. CHEM. 4, 23-32 (1983).

189. J. Seibert and N. Trinajstić

"Chemical Graph Theory. IV. On the Cyclic Polynomial"

INT. J. QUANTUM CHEM. 23, 1829-1841 (1983).

190. J. Debicki-Pospišil, T. Lovrić, N. Trinajstić, and A. Sabljić

"Anthocyanin Degradation in the Presence of Furfural and 5-Hydroxy-methylfurfural"

J. FOOD SCIENCE 48, 411-416 (1983).

191. P. Ilić and N. Trinajstić

"Structural Normalization of Topological Resonance Energy"

CROAT. CHEM. ACTA 56, 203-213 (1983).

192. A. Jurić and N. Trinajstić

"Topological Resonance Energies of Thiocoumarins"

CROAT. CHEM. ACTA 56, 215-219 (1983).

193. O. Mekenyan, D. Bonchev and N. Trinajstić

"Structural Complexity and Molecular Properties of Cyclic Systems with Acyclic Branches"

CROAT. CHEM. ACTA 56, 237-261 (1983).

194. J. V. Knop, W. R. Müller, K. Szymanski, M. Randićand N. Trinajstić

"Note on Acyclic Structures and their Self-returning Walks"

CROAT. CHEM. ACTA 56, 405-409 (1983). 
195. J. V. Knop, D. Plavšić, M. Randić and N. Trinajstić

"Chemical Graph Theory. V. On the Classification of Topological Biradicals"

CROAT. CHEM. ACTA 56, 411-441 (1983).

196. J. V. Knop, K. Szymanski, G. Jashari, and N. Trinajstić

"The Connection Between the Adjacency Matrix and the Boundary Code of Benzenoid Hydrocarbons"

CROAT. CHEM. ACTA 56, 443-450 (1983).

197. P. Křivka and N. Trinajstić

"On the Distance Polynomial of a Graph"

APPL. MATH. 28, 357-363 (1983).

198. A. H. Stollenwerk, B. Kanellakopulos, H. Vogler, A. Jurić and N. Trinajstić

"Magnetic Susceptibilities and Resonance Energies of Annelated [14]- and [18]annulenes"

J. MOL. STRUCT. 102, 377-389 (1983).

199. K. Tabaković, I. Tabaković, M. Trkovnik and N. Trinajstić

"Chemistry of Coumarins. Nucleophilic Substitutions of 4-Chloro-3-nitrocoumarin with Hard and Soft Nucleophiles"

LIEBIGS ANN. CHEM. 1983, 1901-1909.

200. M. Barysz, N. Trinajstić and J. V. Knop

"On the Similarity of Chemical Structures"

INT. J. QUANTUM CHEM.: QUANTUM CHEM. SYMP. 17, 441-451 (1983).

201. J. V. Knop, K. Szymanski and N. Trinajstić

"Computers of Tomorrow"

INT. J. QUANTUM CHEM.: QUANTUM CHEM. SYMP. 17, 629-642 (1983).

202. A. Jurić, A. Sabljić and N. Trinajstić

"Aromaticity in Bridged Heteroannulenes"

J. HETEROCYCL. CHEM. 21, 273-282 (1984).

203. M. Randić and N. Trinajstić

"Conjugation and Aromaticity of Corannulenes"

J. AMER. CHEM. SOC. 106, 4428-4434 (1984).

204. S. El-Basil, P. Krivka and N. Trinajstić

"Application of the Dualist Model. Generation of Kekulé Structures and Resonant Sextets of Benzenoid Hydrocarbons"

CROAT. CHEM. ACTA 57, 339-353 (1984).

205. S. El-Basil and N. Trinajstić

"Application of the Reduced Graph Model to the Sextet Polynomial"

J. MOL. STRUCT. (THEOCHEM) 110, 1-14 (1984).

206. J. V. Knop, K. Szymanski and N. Trinajstić

"A Note on Trees with Polyhexagonal Supervertices"

MATH. CHEM. (Mülheim/Ruhr) 16, 103-118 (1984). 
207. J. V. Knop, K. Szymanski, Ž. Jeričević and N. Trinajstić

"On the Total Number of Polyhexes"

MATH. CHEM. (Mülheim/Ruhr) 16, 119-134 (1984).

208. A. Velenik, T. Živković and N. Trinajstić

"On Bond Orders and Bond Energies in Conjugated Systems"

REV. ROUM. CHIM. 29, 737-740 (1984).

209. S. El-Basil, G. Jashari, J. V. Knop and N. Trinajstić

"Note on the Application of the Reduced Graph Model in Conjunction with Search Trees to the Enumeration of Kekulé Structures"

MONAT. CHEM. 115, 1299-1312 (1984).

210. Ž. Jeričević, N. Trinajstić, D. Petranović and Ž. Trgovčević

"Mathematical Modelling of DNA Replication in UV-Irradiated Bacteria"

STUDIA BIOPHYSICA 102, 97-106 (1984).

211. J. V. Knop, K. Szymanski, L. Klasinc and N. Trinajstić

"Computer Enumeration of Substituted Polyhexes"

COMPUT. CHEM. 8, 107-115 (1984).

212. J. V. Knop, K. Szymanski, N. Trinajstić and P. Krivka

"Computer Generation of All 1-factors for a Class of Graphs With All Vertices of Degree Two or Three"

COMPUT. MATH. APPL. 10, 369-382 (1984).

213. D. J. Klein and N. Trinajstić

"Hückel Rules and Electron Correlation"

J. AMER. CHEM. SOC. 106, 8050-8056 (1984).

214. J. V. Knop, K. Szymanski and N. Trinajstić

"Price-performance Relationship of Microcomputers and Main Frames for Calculations in Theoretical Chemistry"

INT. J. QUANTUM CHEM.: QUANTUM CHEM. SYMP. 18, 639-645 (1984).

215. M. Barysz and N. Trinajstić

"A Novel Approach to the Characterization of Chemical Structures"

INT. J. QUANTUM CHEM.: QUANTUM CHEM. SYMP. 18, 661-673 (1984).

216. M. Grzonka, J. V. Knop, L. Klasinc and N. Trinajstić

"Theoretical Studies on Small Ring Heteropropellanes. Oxapropellanes"

CROAT. CHEM. ACTA 57, 1629-1632 (1984).

217. P. Křivka and N. Trinajstić

"Parity of Kekulé Structures Revisited"

COLL. CZECH. CHEM. COMM. 50, 291-299 (1985).

218. M. Randić, N. Trinajstić, J. V. Knop and Ž. Jeričević

"Aromatic Stability of Heterocyclic Conjugated Systems"

J. AMER. CHEM. SOC. 107, 849-859 (1985). 
219. B. M. Gimarc, A. Jurić and N. Trinajstić

"Sulphur-Nitrogen Rings: Relative Stabilities and Structures"

INORG. CHIM. ACTA 102, 105-112 (1985).

220. N. Adler, D. Babić and N. Trinajstić

"On the Calculation of the HPLC Parameters for Polycyclic Aromatic Hydrocarbons"

FRESENIUS Z. ANAL. CHEM. 322, 426-429 (1985).

221. S. El-Basil, P. Křrivka and N. Trinajstić

"Fibonacci Graphs Possessing Identical Matching Polynomials"

J. MATH. PHYS. 26, 2396-2398 (1985).

222. I. Tabaković, K. Tabaković, R. Grujić, N. Trinajstić and Z. Meić

"Chemistry of Coumarins - Synthesis of Some 3,4-substituted Coumarins Using the HSAB

Principle"

HETEROCYCLES 23, 2539-2542 (1985).

223. K. Szymanski, W. R. Müller, J. V. Knop and N. Trinajstić

"On Randić's Molecular Identification Numbers"

J. CHEM. INF. COMPUT. SCI. 25, 413-415 (1985).

224. M. Barysz, J. V. Knop, S. Pejaković and N. Trinajstić

"Characterization of Branching"

POLISH J. CHEM. 59, 405-432 (1985).

225. B. Pavlović and N. Trinajstić

"On Symmetry and Asymmetry in Literature"

COMPUT. MATH. APPLS. 12B, 197-227 (1986).

226. P. Ilić, B. Sinković and N. Trinajstić

"Molecular Topology in Excited States"

J. MOL. STRUCT. (THEOCHEM) 136, 155-164 (1986).

227. B. Ruščić, P. Křivka and N. Trinajstić

"On the Generalized Approach to the Structure Count"

THEORET. CHIM. ACTA 69, 107-117 (1986).

228. M. Barysz, D. Plavšić and N. Trinajstić

"A Note on Topological Indices"

MATH. CHEM. (Mülheim/Ruhr) 19, 89-116 (1986).

229. M. Barysz, S. Nikolić and N. Trinajstić

"A Note on the Characteristic Polynomial"

MATH. CHEM. (Mülheim/Ruhr) 19, 117-126 (1986).

230. O. Mekenyan, D. Peitchev, D. Bonchev, N. Trinajstić and I. Bangov

"Modelling the Interaction of Small Organic Molecules with Biomacromolecules.

I. Interaction of Substituted Pyridines with Anti-3-azopyridine Antibody"

DRUG RES. 36, 176-183 (1986). 
231. O. Mekenyan, D. Bonchev, N. Trinajstić and D. Peitchev

"Modelling the Interaction of Small Organic Molecules with Biomacromolecules.

II. A Generalized Concept for Biological Interactions"

DRUG RES. 36, 421-424 (1986).

232. O. Mekenyan, D. Peitchev, D. Bonchev, N. Trinajstić and J. Dimitrova

"Modelling the Interaction of Small Organic Molecules with Biomacromolecules.

III. Interaction of Benzoates with Anti-p-(p'-azophenylazo)-benzoate Antibody"

DRUG RES. 36, 629-634 (1986).

233. P. Křivka, Ž. Jeričevič and N. Trinajstić

"On the computation of the Characteristic Polynomial of a Chemical Graph"

INT. J. QUANTUM CHEM.: QUANTUM CHEM. SYMP. 19, 129-147 (1986).

234. M. Randić, B. M. Gimarc and N. Trinajstić

"On the Aromatic Stabilities of Polyacenes and Helicenes"

CROAT. CHEM. ACTA 59, 345-358 (1986).

235. J. V. Knop, K. Szymanski, H. W. Kroto and N. Trinajstić

"Chemical Graph Theory. VII. Enumeration and Generation of the Non-ionic/Radical Members of Cyanopolyyne Family"

CROAT. CHEM. ACTA 59, 359-367 (1986)

236. A. Jurić, N. Trinajstić and G. Jashari

"Aromatic Stability of Bridged Polyenes"

CROAT. CHEM. ACTA 59, 717-633 (1986).

237. P. Křivka, S. Nikolić and N. Trinajstić

"Applications of the Reduced Graph Model. Enumeration of Kekulé Structures for Certain Classes of Large Benzenoid Hydrocarbons"

CROAT. CHEM. ACTA 59, 659-668 (1986).

238. K. Szymanski. W. R. Müller, J. V. Knop and N. Trinajstić

"Molecular ID Numbers"

CROAT. CHEM. ACTA 59, 719-724 (1986).

239. J. V. Knop, W. R. Müller, K. Szymanski and N. Trinajstić

"On the Enumeration of 2-factors of Polyhexes"

J. COMPUT. CHEM. 7, 547-564 (1986).

240. N. Trinajstić, M. Randić and D. J. Klein

"On the Quantitative Structure-Activity Relationships in Drug Research"

ACTA PHARM. JUGOSL. 36, 267-279 (1986).

241. J. V. Knop, W. R. Müller, K. Szymanski, N. Trinajstić, A. Kleiner and M. Randić

"On Irreducible Endospectral Graphs"

J. MATH. PHYS. 27, 2601-2612 (1986). 
242. M. Randić and N. Trinajstić

"On the Relative Stabilities of Conjugated Heterocycles Containing Divalent Sulfur"

SULFUR REPORTS 6, 379-430 (1986).

243. J. V. Knop, W. R. Müller, K. Szymanski and N. Trinajstić

"A Note on the Number of Circulenes"

MATH. CHEM. (Mülheim/Ruhr) 20, 197-208 (1986).

244. K. Szymanski, W. R. Müller, J. V. Knop and N. Trinajstić "On the Identification Numbers for Chemical Structures"

INT. J. QUANTUM CHEM.: QUANTUM CHEM. SYMP. 20, 173-183 (1986)

245. N. Trinajstić, D. J. Klein and M. Randić

"On Some Solved and Unsolved Problems of Chemical Graph Theory"

INT. J. QUANTUM CHEM.: QUANTUM CHEM. SYMP. 20, 699-742 (1986).

246. J. August, H. W. Kroto, and N. Trinajstić

"Interstellar Polyynes and Related Species"

ASTROPHYS. SPACE SCI. 128, 411-419 (1986).

247. W. R. Müller, K. Szymanski, J. V. Knop and N. Trinajstić

"An Algorithm for Construction of the Molecular Distance Matrix"

J. COMPUT. CHEM. 8, 170-173 (1987).

248. O. Mekenyan, D. Bonchev, A. Sabljić and N. Trinajstić

"Application of Topological Indices to QSAR. The Use of the Balaban Index and the Electropy Index for Correlations with Toxicity of Ethers on Mice"

ACTA PHARM. JUGOSL. 37, 75-86 (1987).

249. M. Randić, S. Nikolićand N. Trinajstić

"On the Benzenoid Character of Polycyclic Conjugated Hydrocarbons"

GAZZ. CHIM. ITAL. 117, 69-73 (1987).

250. M. Randić, H. Hosoya, N. Ohkami and N. Trinajstić

"The Generalized Wheland Polynomial"

J. MATH. CHEM. 1, 97-122 (1987).

251. S. Carter, N. Trinajstić and S. Nikolić

"A Note on the Use of ID Numbers in QSAR Studies"

ACTA PHARM. JUGOSL. 37, 37-42 (1987).

252. T. P. Živković and N. Trinajstić

"On the Number of Kekulé Structures of Unbranched Cata-condensed Benzenoid Chains"

CHEM. PHYS. LETT. 136, 141-144 (1987).

253. J. V. Knop, K. Szymanski, W. R. Müller, H. W. Kroto and N. Trinajstić

"Computer Enumeration and Generation of Physical Trees"

J. COMPUT. CHEM. 8, 549-554 (1987). 
254. M. Randić, V. Solomon, S. C. Grossman, D. J. Klein and N. Trinajstić "Resonance Energies of Large Conjugated Hydrocarbons by a Statistical Method" INT. J. QUANTUM CHEM. 32, 35-59 (1987).

255. S. Nikolić, A. Jurić and N. Trinajstić "On the Aromatic Stability of Azulenofurans, Azulenopyrroles and Azulenothiophenes" HETEROCYCLES 26, 2025-2036 (1987).

256. A. T. Balaban, J. Brunvoll, J. Cioslowski, B. N. Cyvin, S. J. Cyvin, I. Gutman, W. C. He, W. J. He, J. V. Knop, M. Kovačević, W. R. Müller, K. Szymanski, R. Tošić and N. Trinajstić "Enumeration of Benzenoid and Coronoid Hydrocarbons"

Z. NATURFORSCH. 42a, 863-870 (1987).

257. Ž. Saničanin, A. Jurić, I. Tabaković and N. Trinajstić

"Synthesis and Electrochemical Study of Benzothiazine and Phenothiazine Derivatives"

J. ORG. CHEM. 52, 4053-4057 (1987).

258. D. J. Klein, T. Živković and N. Trinajstić

"Resonance in Random $\pi$-Electron Polymers"

J. MATH. CHEM. 1, 309-334 (1987).

259. M. Randić and N. Trinajstić

"Critical Test for Resonance Energies"

J. AMER. CHEM. SOC. 109, 6923-6926 (1987).

260. B. Bogdanov, S. Nikolić, A. Sabljić, N. Trinajstić and S. Carter

"On the Use of the Weighted Identification Numbers in the QSAR Study of the Toxicity of Aliphatic Ethers"

INT. J. QUANTUM CHEM.: QUANTUM BIOL. SYMP. 14, 325-330 (1987).

261. M. Randić, S. Nikolićand N. Trinajstić

"On the Aromatic Stability of a Conjugated $\mathrm{C}_{60}$ Cluster"

CROAT. CHEM. ACTA 60, 595-604 (1987).

262. M. Randić and N. Trinajstić

"Composition as a Method for Data Reduction: Application to Carbon-13 NMR Chemical Shifts"

THEORET. CHIM. ACTA 73, 233-246 (1988).

263. H. Vogler and N. Trinajstić

"Phenanth- and Anth-Fused Benzannelated Annulenes: A Graph-Theoretical Study"

J. MOL. STRUCT. (THEOCHEM) 164, 325-334 (1988).

264. P. Křivka, R. B. Mallion and N. Trinajstić

"Chemical Graph Theory. Part VII. The Use of Ulam Subgraphs in Obtaining Characteristic Polynomials"

J. MOL. STRUCT. (THEOCHEM) 164, 363-377 (1988).

265. S. Carter, N. Trinajstić and S. Nikolić

"On the Use of ID Numbers in Drug Research: A QSAR of Neuroleptic Pharmacophores"

MED. SCI. RES. 16, 185-186 (1988). 
266. H. Vogler and N. Trinajstić

"The Conjugated Circuits Model: On the Geometries of Annelated[N]annulenes"

THEORET. CHIM. ACTA 73, 437-448 (1988).

267. M. Randić, S. Nikolić and N. Trinajstić

"Compact Molecular Codes for Polycyclic Systems"

J. MOL. STRUCT. (THEOCHEM) 165, 213-228 (1988).

268. M. Randić, D. Plavšić and N. Trinajstić

"Characterization of Local Benzenoid Features in Polycyclic Conjugated Hydrocarbons" GAZZ. CHIM. ITAL. 118, 441-446 (1988).

269. M. Randić, Ž. Jeričević, A. Sabljić and N. Trinajstić

"On the Molecular Connectivity and $\pi$-Electronic Energy in Polycyclic Hydrocarbons" ACTA PHYS. POLON. 74, 317-330 (1988).

270. N. Trinajstić

"The Characteristic Polynomial of a Chemical Graph"

J. MATH. CHEM. 2, 197-215 (1988).

271. M. Randić, S. Nikolić and N. Trinajstić

"Aromaticity in Heterocyclic Molecules Containing Divalent Sulfur"

COLL. CZECH. CHEM. COMM. 53, 2023-2054 (1988).

272. D. J. Klein, T. G. Schmalz, S. El-Basil, M. Randić and N. Trinajstić

"Kekulé Count and Algebraic Structure Count for Unbranched Alternant Cata-Fusenes"

J. MOL. STRUCT. (THEOCHEM) 179, 99-107 (1988).

273. M. Randić, B. M. Gimarc, S. Nikolićand N. Trinajstić

"On the Aromatic Stabilities of Thiophene Analogues of Helicenes"

J. MOL. STRUCT. (THEOCHEM) 181, 111-140 (1988).

274. M. Randić, A. Sabljić, S. Nikolićand N. Trinajstić

"A Rational Selection of Graph-Theoretical Indices in the QSAR"

INT. J. QUANTUM CHEM.: QUANTUM BIOL. SYMP. 15, 267-285 (1988).

275. M. Randić, L. L. Henderson, R. Stout and N. Trinajstić

"Conjugation and Aromaticity of Macrocyclic Systems"

INT. J. QUANTUM CHEM.: QUANTUM CHEM. SYMP. 22, 127-141 (1988).

276. M. Randić, S. Nikolić and N. Trinajstić

"Enumeration of Kekulé Structures for Helicenic Systems"

CROAT. CHEM. ACTA 61, 821-831 (1988).

277. M. Randić, B. M. Gimarc, S. Nikolićand N. Trinajstić

"On the Aromatic Stability of Helicenic Systems"

GAZZ. CHIM. ITAL. 119, 1-11 (1989).

278. M. Randić, D. Plavšić and N. Trinajstić

"Conjugated Circuits in Excited Valence Structures"

J. MOL. STRUCT. (THEOCHEM) 183, 29-43 (1989). 
279. M. Randić, M. Barysz, J. Nowakowski, S. Nikolićand N. Trinajstić

"Isospectral Graphs Revisited"

J. MOL. STRUCT. (THEOCHEM) 185, 95-121 (1989).

280. M. Randić, D. Plavšić and N. Trinajstić

"Aromaticity in Polycyclic Conjugated Hydrocarbon Dianions"

J. MOL. STRUCT. (THEOCHEM) 185, 249-274 (1989).

281. S. Nikolić, M. Randić, D. J. Klein, D. Plavšić and N. Trinajstić

"The Conjugated-Circuit Model: Application to Benzenoid Hydrocarbons"

J. MOL. STRUCT. (THEOCHEM) 198, 223-237 (1989).

282. W. R. Müller, K. Szymanski, J. V. Knop, S. Nikolić and N. Trinajstić

"On Counting Polyhex Hydrocarbons"

CROAT. CHEM. ACTA 62, 481-483 (1989).

283. N. Trinajstić, D. Plavšić and D. J. Klein

"The Conjugated-Circuit Model Revisited"

CROAT. CHEM. ACTA 62, 709-716 (1989).

284. D. Plavšić, N. Trinajstić, M. Randić and C. Venier

"The Conjugated-Circuit Model: Application to Benzenoid Hydrocarbon Radicals"

CROAT. CHEM. ACTA 62, 717-738 (1989)

285. D. J. Klein and N. Trinajstić

"Foundations of Conjugated-Circuits Models

PURE APPL. CHEM. 61, 2107-2115 (1989).

286. B. Bogdanov, S. Nikolić and N. Trinajstić

"On the Three-dimensional Wiener Number"

J. MATH. CHEM. 3, 299-309 (1989).

287. S. Carter, S. Nikolić and N. Trinajstić

"A Novel Algorithm for QSAR"

INT. J. QUANTUM CHEM.: QUANTUM BIOL. SYMP. 16, 323-330 (1989).

288. D. Amić, A. Jurić and N. Trinajstić

"Topological Resonance Energies of Some Forms of the Flavylium Chromophoric System"

CROAT. CHEM. ACTA 63, 19-26 (1990).

289. J. V. Knop, W. R. Müller, K. Szymanski and N. Trinajstić

"A Note on the Classification and Enumeration of Coronoid Hydrocarbons"

J. MOL. STRUCT. (THEOCHEM) 205, 361-365 (1990).

290. W. R. Müller, K. Szymanski, J. V. Knop, S. Nikolić and N. Trinajstić

"On the Enumeration and Generation of Polyhex Hydrocarbons"

J. COMPUT. CHEM. 11, 223-235 (1990). 
291. D. J. Klein and N. Trinajstić

"Pascal Recurrence Algorithm for Kekulé-Structure Counts of Benzenoid and Coronoid Hydrocarbons"

J. MOL. STRUCT. (THEOCHEM) 206, 135-142 (1990).

292. N. Trinajstić

"On the Classification of Polyhex Hydrocarbons"

J. MATH. CHEM. 5, 171-176 (1990).

293. J. Brunvoll, B. N. Cyvin, S. J. Cyvin, J. V. Knop, W. R. Müller, K. Szymanski and N. Trinajstić "Enumeration and Classification of Coronoid Hydrocarbons: Note to a Note"

J. MOL. STRUCT. (THEOCHEM) 207, 131-139 (1990).

294. S. Nikolić and N. Trinajstić

"Compact Molecular Codes for Annulenes, Aza-annulenes, Annulenoannulenes, Aza-annulenoannulenes, Cyclazines and Aza-cyclazines"

CROAT. CHEM. ACTA 63, 155-169 (1990).

295. M. Randić, D. Plavšić and N. Trinajstić

"On the Difference in Bond Orders Between HMO and PPP Methods"

INT. J. QUANTUM CHEM. 37, 437-448 (1990).

296. J. V. Knop, W. R. Müller, K. Szymanski and N. Trinajstić

"Use of Small Computers for Large Computations: Enumeration of

Polyhex Hydrocarbons"

J. CHEM. INF. COMPUT. SCI. 30, 159-160 (1990).

297. W. R. Müller, K. Szymanski, J. V. Knop and N. Trinajstić

"Molecular Topological Index"

J. CHEM. INF. COMPUT. SCI. 30, 160-163 (1990).

298. M. Randić, B. Jerman-Blažič and N. Trinajstić

"Development of 3-Dimensional Molecular Descriptors"

COMPUT. CHEM. 14, 237-246 (1990).

299. S. Nikolić, N. Trinajstić, J. V. Knop, W. R. Müller and K. Szymanski

"On the Concept of the Weighted Spanning Tree of Dualist"

J. MATH. CHEM. 4, 357-375 (1990).

300. B. Bogdanov, S. Nikolić and N. Trinajstić

"On the Three-Dimensional Wiener Number. A Comment"

J. MATH. CHEM. 5, 305-306 (1990).

301. D. Amić and N. Trinajstić

"On the Lack of Reactivity of Buckminsterfullerene. A Theoretical Study"

J. CHEM. SOC. PERKIN TRANS. II, 1595-1598 (1990).

302. S. Nikolić, N. Trinajstić and D. J. Klein

"The Conjugated-Circuit Model"

COMPUT. CHEM. 14, 313-322 (1990). 
303. D. J. Klein and N. Trinajstić

"Valence Bond Theory and Chemical Structure"

J. CHEM. EDUC. 67, 633-637 (1990).

304. S. Nikolić and N. Trinajstić

"A Theoretical Study of Fully Arenoid Systems"

GAZZ. CHIM. ACTA 120, 685-689 (1990).

305. D. Plavšić, S. Nikolićand N. Trinajstić

"The Conjugated-Circuits Model: On the Selection of the Parameters"

CROAT. CHEM. ACTA 63, 683-692 (1990).

306. J. V. Knop, W. R. Müller, K. Szymanski and N. Trinajstić

"Enumeration of Planar Polyhex Hydrocarbons"

REPORTS IN MOLECULAR THEORY 1, 95-98 (1990).

307. N. Trinajstić

"The Role of Graph Theory in Chemistry"

REPORTS IN MOLECULAR THEORY 1, 185-213 (1990).

308. N. Trinajstić, S. Nikolićand S. Carter

"Mathematical Modelling of Structure-Activity Relationships"

PERIOD. BIOL. 92, 431-432 (1990).

309. N. Trinajstić, T. G. Schmalz, T. P. Živković, S. Nikolić, G. E. Hite, D. J. Klein and W. A. Seitz "[N]phenylenes: A Theoretical Study"

NEW J. CHEM. 15, 27-31 (1991).

310. N. Bošnjak, Z. Mihalić and N. Trinajstić

"Application of Topographic Indices to Chromatographic Data: Calculation of the Retention Indices of Alkanes"

J. CHROMATOGR. 540, 430-440 (1991).

311. J. V. Knop, W. R. Müller, K. Szymanski and N. Trinajstić

"On the Determinant of the Adjacency-Plus-Distance Matrix as the Topological Index for Characterizing Alkanes"

J. CHEM. INF. COMPUT. SCI. 31, 83-84 (1991).

312. B. Jerman-Blažič, S. Nikolićand N. Trinajstić

"The Reduced Graph Model Revisited"

J. MOL. STRUCT. (THEOCHEM) 227, 79-86 (1991).

313. S. Nikolić, N. Trinajstić, Z. Mihalić and S. Carter

"On the Geometric-Distance Matrix and the Corresponding Structural Invariants of Molecular Systems"

CHEM. PHYS. LETT. 179, 21-28 (1991).

314. N. Trinajstić, S. Nikolić and D. J. Klein

"Quantum-Mechanical and Computational Aspects of the Conjugated-Circuit Model"

J. MOL. STRUCT. (THEOCHEM) 229, 63-89 (1991). 
315. D. Amić and N. Trinajstić

"A Theoretical Study of Flavylium Salts"

J. CHEM. SOC. PERKIN TRANS. II, 891-895 (1991).

316. D. Amić and N. Trinajstić

"Activation Hardness as an Index for Predicting the Orientation of Nucleophilic Aromatic Substitution: Application to Flavylium Salts"

BULL. CHEM. SOC. BELG. (European Section) 100, 527-532 (1991).

317. S. Nikolić, N. Trinajstić, J. V. Knop, W. R. Müller and K. Szymanski

"On the Classification and Enumeration of Planar Polyhex Hydrocarbons"

J. MOL. STRUCT. (THEOCHEM) 231, 219-225 (1991).

318. Z. Mihalić and N. Trinajstić

"The Algebraic Modelling of Chemical Structures: On the Development of Three-Dimensional Molecular Descriptors"

J. MOL. STRUCT. (THEOCHEM) 232, 65-78 (1991).

319. D. Plavšić, S. Nikolić and N. Trinajstić

"The Conjugated-Circuit Model: The Optimum Parameters for Benzenoid Hydrocarbons"

J. MATH. CHEM. 8, 113-120 (1991).

320. M. Randić, D. Plavšić and N. Trinajstić

"On the Relative Stability of Nonbenzenoid Alternant Hydrocarbons"

POLYCYCLIC AROMATIC COMPOUNDS 2, 183-194 (1991).

321. M. Randić, D. Plavšić and N. Trinajstić

"Maximum Valence Structures in Nonbenzenoid Polycyclic Hydrocarbons"

STRUCT. CHEM. 2, 543-554 (1991).

322. M. Ivanušević, S. Nikolić and N. Trinajstić

"A QSAR Study of Antidotal Activity of H-Oximes"

REV. ROUM. CHIM. 36, 389-398 (1991).

323. Z. Mihalić, S. Nikolić and N. Trinajstić

"Comparative Study of Molecular Descriptors Derived from the Distance Matrix"

J. CHEM. INF. COMPUT. SCI. 32, 28-37 (1992).

324. N. Trinajstić

"On the Classification of Polyhexes"

J. MATH. CHEM. 9, 373-380 (1992).

325. S. Nikolić, D. Plavšić and N. Trinajstić

"On the Z-counting Polynomial for Edge-Weighted Graphs"

J. MATH. CHEM. 9, 381-387 (1992).

326. D. J. Klein, Z. Mihalić, D. Plavšić and N. Trinajstić

"Molecular Topological Index: A Relation with the Wiener Index"

J. CHEM. INF. COMPUT. SCI. 32, 304-305 (1992). 
327. D. Plavšić, N. Trinajstić and D. J. Klein

"Clar Structures in Fractal Benzenoids"

CROAT. CHEM. ACTA 65, 279-284 (1992).

328. A. Jurić, M. Gagro, S. Nikolić and N. Trinajstić

"Molecular Topological Index: An Application in the QSAR Study of Toxicity of Alcohols"

J. MATH. CHEM. 11, 179-186 (1992).

329. Z. Mihalić, D. Veljan, D. Amić, S. Nikolić, D. Plavšić and N. Trinajstić

"The Distance Matrix in Chemistry"

J. MATH. CHEM. 11, 223-258 (1992).

330. D. Amić, N. Trinajstić and D. Davidović-Amić

"Experimental and Theoretical Study of the Styrylbenzopyrilium Chromophore"

J. CHEM. SOC. PERKIN TRANS. II, 1933-1938 (1992).

331. Z. Mihalić and N. Trinajstić

"A Graph-Theoretical Approach to Structure-Property Relationships"

J. CHEM. EDUC. 69, 701-712 (1992).

332. D. Horvat, A. Graovac, D. Plavšić, N. Trinajstić and M. Strunje

"On the Intercorrelation of Topological Indices in Benzenoid Hydrocarbons"

INT. J. QUANTUM CHEM.: QUANTUM CHEM. SYMP. 26, 401-408 (1992).

333. D. Plavšić, S. Nikolić and N. Trinajstić

"The Conjugated-Circuit Model: Application to Non-alternant Hydrocarbons and a Comparison

With Some Other Theoretical Models of Aromaticity"

J. MOL. STRUCT. (THEOCHEM) 277, 213-237 (1992).

334. D. Babić and N. Trinajstić

"Resonance Energy of Conjugated Hydrocarbons Derived by Cluster Expansion"

CROAT. CHEM. ACTA 65, 881-892 (1992).

335. B. Mohar, D. Babić and N. Trinajstić

"A Novel Definition of the Wiener Index for Trees"

J. CHEM. INF. COMPUT. SCI. 33, 153-154 (1993).

336. D. Juretić, B. Lee, N. Trinajstić and R. W. Williams

"Conformational Preference Functions for Predicting Helices in Membrane Proteins"

BIOPOLYMERS 33, 255-273 (1993).

337. W. R. Müller, K. Szymanski, J. V. Knop, Z. Mihalić and N. Trinajstić

"The Walk ID Number Revisited"

J. CHEM. INF. COMPUT. SCI. 33, 231-233 (1993).

338. D. Plavšić, S. Nikolić, N. Trinajstić and Z. Mihalić

"On the Harary Index for the Characterization of Chemical Graphs"

J. MATH. CHEM. 12, 235-250 (1993). 
339. S. Nikolić, N. Trinajstić and Z. Mihalić

"Molecular Topological Index: An Extension to Heterosystems"

J. MATH. CHEM. 12, 251-264 (1993).

340. D. Plavšić, D. Babić, S. Nikolićand N. Trinajstić

"A Comparative Study of Several Simple Aromaticity Models for Benzenoid Hydrocarbons"

GAZZ. CHIM. ITAL. 123, 243-249 (1993).

341. D. Juretić, N. Trinajstić and B. Lučić

"Protein Secondary Structure Conformations and Associated Hydrophobic Scales"

J. MATH. CHEM. 14, 35-45 (1993).

342. D. Babić, A. Graovac and N. Trinajstić

"On the HOMO-LUMO Separation in Fullerenes"

CROAT. CHEM. ACTA 66, 35-47 (1993).

343. D. Juretić, B. Lučić and N. Trinajstić

"Predicting Membrane Protein Secondary Structure: Preference Functions Method for Finding Optimal Conformational Parameters"

CROAT. CHEM. ACTA 66, 201-208 (1993).

344. N. Trinajstić

"The Magic of the Number Five"

CROAT. CHEM. ACTA 66, 227-254 (1993).

345. W. R. Müller, K. Szymanski, J. V. Knop and N. Trinajstić

"On the Number of Square-Cell Configurations"

THEORET. CHIM. ACTA 86, 269-278 (1993).

346. M. Randićand N. Trinajstić

"Viewpoint 4 - Comparative Structure-Property Studies: The Connectivity Basis"

J. MOL. STRUCT. (THEOCHEM) 284, 209-221 (1993).

347. J. V. Knop, W. R. Müller, K. Szymanski, S. Nikolić and N. Trinajstić

"On the Concept of Fully-Arenoid Hydrocarbons"

MATH. CHEM. (Mülheim/Ruhr) 29, 81-106 (1993).

348. D. Babić and N. Trinajstić

"Pyracylene Rearrangement Classes of Fullerene Isomers"

COMPUT. CHEM. 17, 271-275 (1993).

349. M. Randić, N. Trinajstić, L. L. Henderson and R. P. Stout

"A Note on the Enumeration of Kekulé Structures in a Class of Coronoids"

J. MOL. STRUCT. (THEOCHEM) 285, 121-128 (1993).

350. D. Plavšić, S. Nikolić, N. Trinajstić and D. J. Klein

"Relation between the Wiener Index and the Schultz Index for Several Classes of Chemical

Graphs"

CROAT. CHEM. ACTA 66, 345-353 (1993). 
351. D. Amić, D. Davidović-Amić and N. Trinajstić

"Application of Topological Indices to Chromatographic Data: Calculation of the Retention Indices of Anthocyanins"

J. CHROMATOGR. A 653, 115-121 (1993).

352. M. Randić and N. Trinajstić

"In Search for Graph Invariants of Chemical Interest"

J. MOL. STRUCT. (THEOCHEM) 300, 551-572 (1993).

353. M. Randić, Z. Mihalić, S. Nikolić and N. Trinajstić

"Graph-Theoretical Correlations - Artfacts or Facts"

CROAT. CHEM. ACTA 66, 411-434 (1993).

354. D. Babić and N. Trinajstić

"On the K $(4 n+2)$ Rule for Fullerenes"

J. MOL. STRUCT. (THEOCHEM) 303, 283-286 (1994).

355. N. Trinajstić, D. Babić, S. Nikolić, D. Plavšić, D. Amić and Z. Mihalić

"The Laplacian Matrix in Chemistry"

J. CHEM. INF. COMPUT. SCI. 34, 368-376 (1994).

356. M. Randić, Z. Mihalić, S. Nikolić and N. Trinajstić

"Graphical Bond Orders: Novel Structural Descriptors"

J. CHEM. INF. COMPUT. SCI. 34, 403-409 (1994).

357. Z. Mihalić and N. Trinajstić

"On the Number of Spanning Trees in Fullerenes"

FULLERENE SCIENCE \& TECHNOLOGY 2, 89-95 (1994).

358. M. Randićand N. Trinajstić

"Isomeric Variations in Alkanes: Boiling Points of Nonanes"

NEW J. CHEM. 18, 179-189 (1994).

359. D. J. Klein, M. Randić, D. Babić and N. Trinajstić

"On Conjugated-Circuit Polynomials"

INT. J. QUANTUM CHEM. 50, 369-384 (1994).

360. D. Amić, D. Davidović-Amić and N. Trinajstić

"Theoretical Study of the 5,6-Benzoflavylium Chromophore"

GAZZ. CHIM. ITAL. 124, 53-56 (1994).

361. W. R. Müller, K. Szymanski, J. V. Knop and N. Trinajstić

"Bit-tuple Notation for Trees"

J. CHEM. INF. COMPUT. SCI. 34, 960-961 (1994).

362. Z. Mihalić, D. Babić and N. Trinajstić

"Benzenoid Graphs with Equal Maximum Eigenvalues"

J. MATH. CHEM. 15, 407 (1994). 
363. M. Randić and N. Trinajstić

"Notes on Some Less Known Early Contributions to Chemical Graph Theory"

CROAT. CHEM. ACTA 67, 1-35 (1994).

364. D. Babić, N. Trinajstić and D. J. Klein

"A Note on a Variant of the Leapfrog Transformation of Chemical Graphs"

CROAT. CHEM. ACTA 67, 37-44 (1994).

365. D. Davidović-Amić, D. Amić and N. Trinajstić

"4-Carboxyflavylium Salts: Stable Red Dyes?"

CROAT. CHEM. ACTA 67, 163-170 (1994).

366. M. Randić, D. J. Klein, H. Zhu, N. Trinajstić and T. Živković

"Aromatic Properties of Fully-Benzenoid Hydrocarbons"

FIZIKA A 3, 61-75 (1994).

367. D. Babić and N. Trinajstić

"On Assembling Fullerenes from Identical Fragments"

FULLERENE SCIENCE \& TECHNOLOGY 2, 343-356 (1994).

368. D. Babić and N. Trinajstić

"Kekulene and Antikekulene"

J. MOL. STRUCT. (THEOCHEM) 314, 321-327 (1994).

369. N. Trinajstić, Z. Mihalić and F. E. Harris

"A Note on the Number of Spanning Trees in Buckminsterfullerene"

INT. J. QUANTUM CHEM.: QUANTUM CHEM. SYMP. 28, 525-528 (1994).

370. S. Nikolić, M. Medić-Šarić, S. Rendić and N. Trinajstić

"Toxic Effects and a Structure-Property Study of Organic Explosives, Propellants and Related

Compounds"

DRUG METABOLISM REV. 26, 717-738 (1994).

371. N. Trinajstić, S. Nikolić and Z. Mihalić

"On the Complexity of Platonic Solids"

BULLETIN OF THE CHEMISTS TECHNOLOGISTS OF MACEDONIA 13, 61-68 (1994).

372. M. Randić, D. J. Klein, H.-Y. Zhu, N. Trinajstić and T. Živković

"Comparative Study of Large Molecules. Highly Accurate Calculation of a Limit for Infinite Systems from Data on Finite Systems"

THEORET. CHIM. ACTA 90, 1-26 (1995).

373. D. Amić, D. Davidović-Amić and N. Trinajstić

"Calculation of Retention Times of Anthocyanins with Orthogonalized Topological Indices"

J. CHEM. INF. COMPUT. SCI. 35, 136-139 (1995).

374. W. R. Müller, K. Szymanski, J. V. Knop and N. Trinajstić

"A Comparison between the Matula Numbers and Bit-tuple Notation for Rooted Trees"

J. CHEM. INF. COMPUT. SCI. 35, 211-213 (1995). 
375. T. Živković, M. Randić, D. J. Klein, H.-Y. Zhu and N. Trinajstić

"Analytical Approach to Very Large Benzenoid Polymers"

J. COMPUT. CHEM. 16, 517-526 (1995).

376. D. Amić and N. Trinajstić

"On the Detour Matrix"

CROAT. CHEM. ACTA 68, 53-62 (1995).

377. N. Trinajstić, W. R. Müller, K. Szymanski and J. V. Knop

"On the Complexity of Square-Cell Configurations"

CROAT. CHEM. ACTA 68, 91-98 (1995).

378. S. Nikolić, N. Trinajstić and Z. Mihalić

"The Wiener Index: Development and Applications"

CROAT. CHEM. ACTA 68, 105-129 (1995).

379. N. Trinajstić, M. Randić, D. J. Klein, D. Babić and Z. Mihalić

"On Mathematical Properties of Buckminsterfullerene"

CROAT. CHEM. ACTA 68, 241-267 (1995).

380. D. Babić and N. Trinajstić

"Stability of Fullerenes with Four-Membered Rings"

CHEM. PHYS. LETT. 237, 239-245 (1995)

381. H. Vančik, D. Babić and N. Trinajstić

"C 60 - An Abiotic Terpenoid?"

FULLERENE SCIENCE \& TECHNOLOGY 3, 305-312 (1995).

382. M. Randić, S. Nikolić and N. Trinajstić

"Compact Codes: On Nomenclature of Acyclic Chemical Compounds"

J. CHEM. INF. COMPUT. SCI. 35, 357-365 (1995).

383. B. Lučić, S. Nikolić, N. Trinajstić and D. Juretić

"The Structure-Property Models Can Be Improved Using the Orthogonalized Descriptors"

J. CHEM. INF. COMPUT. SCI. 35, 532-538 (1995).

384. D. Babić and N. Trinajstić

"Resonance Energies of Fullerenes with 4-Membered Rings"

INT. J. QUANTUM CHEM. 55, 309-314 (1995).

385. W. R. Müller, K. Szymanski, J. V. Knop and N. Trinajstić

"A Remark on the Naming of Cata-Condensed Benzenoids with Base 5 Numbers"

J. CHEM. INF. COMPUT. SCI. 35, 759-760 (1995).

386. B. Lučić, S. Nikolić, N. Trinajstić, A. Jurić and Z. Mihalić

"A Structure-Property Study of the Solubility of Aliphatic Alcohols in Water"

CROAT. CHEM. ACTA 68, 417-434 (1995).

387. B. Lučić, S. Nikolić, N. Trinajstić, D. Juretić and A. Jurić

"A Novel QSPR Approach to Physicochemical Properties of the $\alpha$-Amino Acids" CROAT. CHEM. ACTA 68, 435-450 (1995). 
388. N. Trinajstić

"On Theoretical Research in Biology"

PERIOD. BIOL. 97, 177-182 (1995).

389. N. Trinajstić

"Ethics in Genetics. A Comment"

PERIOD. BIOL. 97, 249-250 (1995).

390. D. Juretić, B. Lučić and N. Trinajstić

"Secondary Structure Prediction Quality for Naturally Occurring Amino Acids in Soluble Proteins" J. MOL. STRUCT. (THEOCHEM) 338, 43-50 (1995).

391. D. J. Klein, A. Graovac, Z. Mihalić and N. Trinajstić "Excitation Spectra for Degenerate Rearrangements"

J. MOL. STRUCT. (THEOCHEM) 341, 157-164 (1995).

392. D. Amić, D. Davidović-Amić, A. Jurić, B. Lučić and N. Trinajstić

"Structure-Activity Correlation of Flavone Derivatives for Inhibition of cAMP Phosphodiesterase"

J. CHEM. INF. COMPUT. SCI. 35, 1034-1038 (1995).

393. M. Šoškić, D. Plavšić and N. Trinajstić

"2-Difluoromethylthio-4,6-bis(monoalkylamino)-1,3,5-triazines as Inhibitors of Hill Reaction:

A QSAR Study with Orthogonalized Descriptors"

J. CHEM. INF. COMPUT. SCI. 36, 146-150 (1996).

394. D. Babić and N. Trinajstić

"On the Assembling of Fullerenes from Cyclocarbons"

J. MOL. STRUCT. 376, 507-511 (1996).

395. D. Babić and N. Trinajstić

Symmetric Decomposition of Buckminsterfullerene

COMM. MATH. COMPUT. CHEM. 33, 17-24 (1996).

396. D. Babić and N. Trinajstić

Möbius Inversion on a Poset of a Graph and Its Acyclic Subgraphs

DISCRETE APPL. MATH. 67, 5-11 (1996).

397. M. Šoškić, D. Plavšić and N. Trinajstić

"Link between Orthogonal and Standard Multiple Linear Regression Models"

J. CHEM. INF. COMPUT. SCI. 36, 829-832 (1996).

398. B. Kiralj, B. Kojić-Prodić, M. Žinić, S. Alihodžić and N. Trinajstić

"Bond Length-Bond Order Relations and Calculated Geometries for Some Benzenoid Aromatics, Including Phenanthridine. Structures of 5,6-Dimethylphenanthridinium Triflate, [N-(6Phenanthridinylmethyl)-aza-18-crown-6- $\left.\kappa^{5} O, O^{\prime}, O^{\prime \prime}, O^{\prime \prime}, O^{\prime \prime \prime}\right]\left(\right.$ picrate- $\left.\kappa^{2} O, O^{\prime}\right)$ potassium, and [N,N'-Bis(6-phenanthridinyl- $\kappa N$-methyl)-7,16-diaza-18-crown-6- $\kappa^{4} O, O^{\prime}, O^{\prime \prime}, O^{\prime \prime}$ '] sodium Iodide Dichloromethane Solvate"

ACTA CRYST. B 52, 823-837 (1996). 
399. S. Nikolić, N. Trinajstić, A. Jurić, Z. Mihalić and G. Krilov "Complexity of Some Interesting (Chemical) Graphs"

CROAT. CHEM. ACTA 69, 883-897 (1996).

400. N. Trinajstić

"On the Nature of Theoretical Research"

CROAT. CHEM. ACTA 69, 1013-1022 (1996).

401. D. Plavšić, M. Šoškić, I. Landeka and N. Trinajstić

"On the Relation between the P'/P Index and the Wiener Number"

J. CHEM. INF. COMPUT. SCI. 36, 1123-1126 (1996).

402. N. Trinajstić, S. Nikolić, B. Lučić and D. Amić

"On QSAR Modeling"

ACTA PHARM. 45, 24-263 (1996).

403. S, Nikolić, N. Trinajstić, A. Jurić and Z. Mihalić

"The Detour Matrix and the Detour Index of Weighted Graphs"

CROAT. CHEM. ACTA 69, 1577-1591 (1996).

404. M. V. Diudea, O. Ivanciuc, S. Nikolić and N. Trinajstić

"Matrices of Reciprocal Distance, Polynomials and Derived Numbers"

MATCH - COMM. MATH. COMPUT. CHEM. 35, 41-64 (1997).

405. D. J. Klein, M. Randić, D. Babić, B. Lučić, S. Nikolićand N. Trinajstić

"Hierarchical Orthogonalization of Descriptors"

INT. J. QUANTUM CHEM. 63, 215-222 (1997).

406. D. Amić, D. Davidović-Amić, D. Bešlo, B. Lučić and N. Trinajstić

"The Use of the Ordered Orthogonalized Multivariate Linear Regression in a Structure-Activity Study of Coumarin and Flavonoid Derivatives as Inhibitors of Aldose Reductase"

J. CHEM. INF. COMPUT. SCI. 37, 581-586 (1997).

407. M. Šoškić, D. Plavšić and N. Trinajstić

"Inhibition of the Hill Reaction by 2-Methylthio-4,6-bis(monoalkylamino)-1,3,5-triazines.

A QSAR Study"

J. MOL. STRUCT. (THEOCHEM) 394, 57-65 (1997).

408. N. Trinajstić, S. Nikolić, D. Babić and Z. Mihalić

"The Vertex- and Edge-Connectivity Indices of Platonic and Archimedean Molecules"

BULLETIN OF THE CHEMISTS AND TECHNOLOGISTS OF MACEDONIA 16, 43-51 (1997).

409. N. Trinajstić, S. Nikolić, B. Lučić. D. Amić and Z. Mihalić

"The Detour Matrix in Chemistry"

J: CHEM. INF. COMPUT. SCI. 37, 631-638 (1997).

410. S. Nikolić and N. Trinajstić

"On the Concept of a Chemical Model"

CROAT. CHEM. ACTA 70, 777-786 (1997). 
411. A. Jurić, S. Nikolić and N. Trinajstić

"Topological Resonance Energies of Thienopyrimidines"

CROAT. CHEM. ACTA 70, 841-846 (1997).

412. B. Jurišić, M. Flögel, S. Nikolić and N. Trinajstić

"Kinetic and Thermodynamic Characterisation of $\mathrm{N}_{\alpha}$-Acetyl Microperoxidase- 8 Interaction with Hydrogen Peroxide and Acetyl Hydroperoxide"

ACTA PHARM. 47, 149-158 (1997).

413. I. M. Tolić and N. Trinajstić

"What Is Life? Is It Just a Physico-Chemical Process of High Complexity?"

PERIOD. BIOL. 99, 295-302 (1997).

414. D. Amić, D. Davidović-Amić, D. Bešlo, B. Lučić and N. Trinajstić

"A Simple QSAR Model for Trypsin Aminopeptidase Inhibitory Flavonoids"

CROAT. CHEM. ACTA 70, 905-911 (1997).

415. N. Trinajstić, S. Nikolić and Z. Mihalić

"On Computing the Molecular Detour Matrix"

INT. J. QUANTUM CHEM. 65, 415-419 (1997).

416. M. Randić, W. R. Müller, J. V. Knop and N. Trinajstić

"The Characteristic Polynomial as a Structure Discriminator"

J. CHEM. INF. COMPUT. SCI. 37, 1072-1077 (1997).

417. M. Vedrina, S. Marković, M. Medić-Šarić and N. Trinajstić

"TAM: A Program for the Calculation of Topological Indices in QSPR and QSAR Studies" COMPUT. CHEM. 21, 355-361 (1997).

418. B. Lučić and N. Trinajstić

"New Developments in QSPR/QSAR Modeling Based on Topological Indices"

SAR QSAR ENVIRON. RES. 7, 45-62 (1997).

419. S. Nikolić, N: Trinajstić and I. Baučić

"Comparison between the Vertex- and Edge-Connectivity Indices for Benzenoid Hydrocarbons"

J. CHEM. INF. COMPUT. SCI. 38, 42-46 (1998).

420 B. Kiralj, B. Kojić-Prodić, S. Nikolićand N. Trinajstić

"Bond Lengths and Bond Orders in Benzenoids: A Comparison of the Valence Bond and Molecular Orbital Treatments"

J. MOL. STRUCT.- THEOCHEM 427, 25-37 (1998).

421. D. Juretić, D. Zucić, B. Lučić and N. Trinajstić

"Preference Functions for Prediction of Membrane-buried Helices in Integral Membrane Proteins" COMPUT. CHEM. 22, 279-294 (1998).

422. M. Randić, S. El-Basil, S. Nikolić and N. Trinajstić

"Clar Polynomials of Large Benzenoid Systems"

J. CHEM. INF. COMPUT. SCI. 38, 563-574 (1998). 
423. D. Amić, D. Davidović-Amić, D. Bešlo, B. Lučić and N. Trinajstić "QSAR of Flavylium Salts as Inhibitors of Xanthine Oxidase"

J. CHEM. INF. COMPUT. SCI. 38, 815-818 (1998).

424. D. Amić, D. Bešlo, B. Lučić, S. Nikolić and N. Trinajstić

"The Vertex-Connectivity Index Revisited"

J. CHEM. INF. COMPUT. SCI. 38, 819-822 (1998).

425. M. V. Diudea, G. Katona, I. Lukovits and N. Trinajstić

"Detour and Cluj-Detour Indices"

CROAT. CHEM. ACTA 71, 459-471 (1998).

426. D. Plavšić, N. Trinajstić, D. Amić and M. Šoškić

"Comparison between the Structure-Boiling Point Relationships with Different Descriptors for

Condensed Benzenoids"

NEW J. CHEM. 22, 1075-1078 (1998).

427. I. M. Tolić and N. Trinajstić

"The Number Five in Biology"

PERIOD. BIOL. 100, 259-265 (1998).

428. S. Nikolić and N. Trinajstić

"Modeling the Aqueous Solubility of Aliphatic Alcohols"

SAR QSAR ENVIRON. RES. 9, 117-126 (1998).

429. I. M. Tolić and N. Trinajstić

"Origin of Life: Earth or Outer Space?"

PERIOD. BIOL. 100, 405-410 (1998).

430. B. Lučić and N. Trinajstić

"Multivariate Regression Outperforms Several Robust Architectures of Neural Networks in QSAR Modeling"

J. CHEM. INF. COMPUT. SCI. 39, 121-132 (1999).

431. I. Lukovits, S. Nikolić and N. Trinajstić

"Resistance Distance in Regular Graphs"

INT. J. QUANTUM CHEM. 71, 217-225 (1999).

432. B. Lučić, N. Trinajstić, S. Sild, M. Karelson and A. R. Katritzky

"A New Efficient Approach for Variable Selection Based on Multiregression: Prediction of Gas Chromatographic Retention Times and Response Factors"

J. CHEM. INF. COMPUT. SCI. 39, 610-621 (1999).

433. S. Nikolić, N. Trinajstić and S. Ivaniš

"The Connectivity Indices of Regular Graphs"

CROAT. CHEM. ACTA 72, 875-883 (1999).

434. S. Nikolić, I. M. Tolić and N. Trinajstić

"On the Complexity of Molecular Graphs"

MATCH - COMM. MATH. COMPUT. CHEM. 40, 187-201 (1999). 
435. D. Amić, D. Davidović-Amić, D. Bešlo, B. Lučić and N. Trinajstić

"Prediction of pK Values, Half-Lives and Electronic Spectra of Flavylium Salts from Molecular Structure"

J. CHEM. INF. COMPUT. SCI. 39, 967-973 (1999).

436. S. C. Basak, B. D. Gute, B. Lučić, S. Nikolić and N. Trinajstić

"A Comparative QSAR Study of Benzamidines Complement- Inhibitory Activity and Benzene Derivatives Acute Toxicity"

COMPUT. CHEM. 24, 181-191 (2000).

437. A. R. Katritzky, K. Chen, Y. Wang, M. Karelson, B. Lučić, N. Trinajstić, T. Suzuki and G. Schüürmann,

"Prediction of Liquid Viscosity for Organic Compounds by a Quantitative Structure-Property Relationship.

J. PHYS. ORG. CHEM. 13, 80-86 (2000).

438. B. Lučić, D. Amić and N. Trinajstić

"Nonlinear Multivariate Regression Outperforms Several Concisely Designed Neural Networks on Three QSPR Data Sets"

J. CHEM. INF. COMPUT. SCI. 40, 403-413 (2000).

439. D. Amić, D. Davidović-Amić, D. Bešlo and N. Trinajstić

"Vitisin-Type Pigments: Possible novel Food Colors"

CROAT. CHEM. ACTA 73, 511-516 (2000).

440. S. Nikolić, N. Trinajstić and I. M. Tolić

"Complexity of Molecules"

J. CHEM. INF. COMPUT. SCI. 40, 920-926 (2000).

441. S. C. Basak, S. Nikolić, N. Trinajstić, D. Amić and D. Bešlo, "QSPR Modeling: Graph Connectivity Indices versus Line Graph Connectivity Indices" J. CHEM. INF. COMPUT. SCI. 40, 927-933 (2000).

442. S. Nikolić, I. M. Tolić, N. Trinajstić and I. Baučić

"On the Zagreb Indices as Complexity Indices"

CROAT. CHEM. ACTA 73, 909-921 (2000).

443. I. Lukovits, S. Nikolić and N. Trinajstić

"Note on the Resistance Distances in the Dodecahedron"

CROAT. CHEM. ACTA 73, 957-967 (2000).

444. S. Nikolić, N. Trinajstić and M. Randić

"Wiener Index Revisited"

CHEM. PHYS. LETT. 333, 319-321 (2001).

445. V. Paar, N. Pavin, A. Rubčić, J. Rubčić and N. Trinajstić

"Scale-Invariant Power Law and Fractality for Molecular Weights"

CHEM. PHYS. LETT. 336, 129-134 (2001). 
446. D. Amić, B. Lučić, S. Nikolić and N. Trinajstić

"Predicting Inhibition of Microsomal p-Hydroxylation of Aniline by Aliphatic Alcohols:

A QSAR Approach Based on Weighted Path Numbers"

CROAT. CHEM. ACTA 74, 237-250 (2001).

447. D. Babić and N. Trinajstić

"Planar Rearrangements of Fullerenes"

J. MOL. GRAPHICS MODELLING 19, 210-215 (2001).

448. B. Lučić, I. Lukovits, S. Nikolić and N. Trinajstić

"Distance-Related Indexes in the Quantitative Structure-Property Relationship Modeling"

J. CHEM. INF. COMPUT. SCI. 41, 527-535 (2001).

449. N. Trinajstić, S. Nikolić, S. C. Basak and I. Lukovits

"Distance Indices and Their Hyper-Counterparts: Intercorrelation and Use in the StructureProperty Modeling"

SAR QSAR ENVIRON. RES. 12, 31-54 (2001).

450. D. Bonchev and N. Trinajstić

"Overall Molecular Descriptors. 3. Overall Zagreb Indices"

SAR QSAR ENVIRON. RES. 12, 213-236 (2001).

451. S. Nikolić, D. Plavšić and N. Trinajstić

"On the Balaban-Like Topological Indices"

MATCH - COMMUN. MATH. COMPUT. CHEM. 44 (2001) 361-386.

452. D. Amić, S. C. Basak, B. Lučić, S. Nikolić and N. Trinajstić

"Structure-Water Solubility Modeling of Aliphatic Alcohols Using the Weighted Path Numbers"

SAR QSAR ENVIRON. RES. 13 (2002) 281-295.

453. I. Lukovits, S. Nikolić and N. Trinajstić

"On Relationship Between Vertex-Degrees, Path-Numbers and Graph Valence-Shells in Trees" CHEM. PHYS. LETT. 354 (2002) 417-422.

454. B. Lučić, I. Bašic, D. Nadramija, A., Miličević, N. Trinajstić, T. Suzuki, R. Petrukhin, M. Karelson and A. R. Katritzky

"Correlation of Liquid Viscosity with Molecular Structure Using Different Variable Selection Methods"

ARKIVOC 2002 (IV), 45-49.

http://www.arkat-usa.org/

455. D. Babić, D. J. Klein, I. Lukovits, S. Nikolićand N. Trinajstić

"Resistance-Distance Matrix: A Computional Algorithm and Its Application"

INT. J. QUANTUM CHEM. 90 (2002) 166-176.

456. I. Lukovits, A. Miličević, S. Nikolić and N. Trinajstić

"On Walk Counts and Complexity of General Graphs"

INTERNET ELECTRONIC J. MOL. DESIGN 1 (2002) 388-400.

http://www.biochempress.com/ 
457. B. Lučić, A. Miličević, S. Nikolić and N. Trinajstić "Harary Index - Twelve Years Later"

CROAT. CHEM. ACTA 75 (2002) 847-868.

458. R. B. Mallion and N. Trinajstić

"Reciprocal Spanning-Tree Density: A New Index Characterising the Intricacy of (Poly)cyclic Molecular-Graph"

MATCH - COMMUN. MATH. COMPUT. CHEM. 48 (2003) 97-116.

459. I. Lukovits, A. Graovac, E. Kálmán, G. Kaptay, P. Nagy, S. Nikolić, J. Sytchev and N. Trinajstić "Nanotubes: Number of Kekulé Structures and Aromaticity"

J. CHEM. INF. COMPUT. SCI. 43 (2003) 609-614.

460. A. Miličević, S. Nikolić, D. Plavšić and N. Trinajstić

"On the Hosoya Z-Index of General Graphs"

INTERNET ELECTRONIC J. MOL. DESIGN 2 (2003) 160-178.

http://www.biochempress.com

461. D. Amić, D. Davidović-Amić, D. Bešlo and N. Trinajstić

"Structure-Radical Scavenging Activity Relationship of Flavonoids"

CROAT. CHEM. ACTA 76 (2003) 55-61.

462. S. Nikolić, G. Kovačević, A. Miličević and N. Trinajstić

"The Zagreb Indices 30 Years After"

CROAT. CHEM. ACTA 76 (2003) 113-124.

463. D. Vukičević and N. Trinajstić

"Modified Zagreb Index $M_{2}$ - Comparison with the Randić Connectivity Index for Benzenoid Systems"

CROAT. CHEM. ACTA 76 (2003) 183-187.

464. B. Lučić, A. Miličević, S. Nikolić and N. Trinajstić

"On Variable Wiener Index"

INDIAN J. CHEM. 42A (2003) 1279-1282.

465. B. Lučić, N. Trinajstić, Bašic and D. Nadramija

"Toward Generating Simpler QSAR Models: Nonlinear Multivariate Regression versus Several Neural Network Ensembles and Some Related Methods"

J. CHEM. INF. COMPUT. SCI. 43 (2003) 1094-1102.

466. I. Lukovits and N. Trinajstić

"Atomic Walk Counts of Negative Order"

J. CHEM. INF. COMPUT. SCI. 43 (2003) 1110-1114.

467. T. Piližota, B. Lučić and N. Trinajstić

"Use of Variable Selection in Modeling the Secondary Structural Content of Proteins from Their Composition of Amino Acid Residues"

J. CHEM. INF. COMPUT. SCI. 44 (2004) 113-121. 
468. A. Miličević, S. Nikolić and N. Trinajstić

"Coding and Ordering Kekulé Structures"

J. CHEM. INF. COMPUT. SCI. 44 (2004) 415-421.

469. L. Pogliani, M. Randić and N. Trinajstić

"What Can Be Said About the Number 13 Beyond the Fact That It Is a Prim Number?"

CROAT. CHEM. ACTA 77 (2004) 447-456.

470. A. Miličević, S. Nikolić and N. Trinajstić

"On Reformulated Zagreb Indices"

MOLECULAR DIVERSITY 8 (2004) 393-399.

471. D. J. Klein, J. L. Palacios, M. Randić and N. Trinajstić

"Random Walks and Chemical Graph Theory"

J. CHEM. INF. COMPUT. SCI. 44 (2004) 1521-1525.

472. D. Vukičević and N. Trinajstić

"Wiener Indices of Benzenoid Graphs"

BULLETIN OF THE CHEMISTS AND TECHNOLOGISTS OF MACEDONIA 23 (2004) 113-129.

473. S. Nikolić, A. Miličević, N. Trinajstić and A. Jurić

"On the Use of the Variable Zagreb ${ }^{v} M_{2}$ Index in QSPR: Boiling Points of Benzenoid Hydrocarbons"

MOLECULES 9 (2004) 1208-1221.

474. D. Vukičević and N. Trinajstić

"On the Discriminatory Power of the Zagreb Indices for Molecular Graphs"

MATCH COMMUN. MATH. COMPUT. CHEM. 53 (2005) 111-138.

475. D. Vukičević, S. Nikolić and N. Trinajstić

"On the Schultz Index of Thorn Graphs"

INTERNET ELECTRONIC J. MOL. DESIGN 4 (2005) 501-514.

http://www.biochempress.com

476. D. Vukičević, A. Miličević, S. Nikolić, J. Sedlar and N. Trinajstić

"Paths and Walks in Acyclic Structures: Plerographs versus Kenographs "

ARKIVOC 2005 (X), 33-44.

http://www.arkat-usa.org

477. D. Vukičević and N. Trinajstić

"Comparison of the Hosoya Z-Index for Simple and General Graphs of the Same Size"

CROAT. CHEM. ACTA 78 (2005) 223-239.

478. S Nikolić, A. Miličević and N. Trinajstić

"On Graphical Matrices

CROAT. CHEM. ACTA 78 (2005) 241-250.

479. B. Hollas, I. Gutman and N. Trinajstić

"On Reducing Correlations between Topological Indices"

CROAT. CHEM. ACTA 78 (2005) 489-492. 
480. D. Juretić, B. Lučić and N. Trinajstić

"Why Focusing on Bioinformatics?"

PERIOD. BIOL. 107 (2005) 379-383.

481. I. Lukovits, A. Miličević, N. Trinajstić and D. Vukičević,

"Kekulé-Structure Counts in Damaged Benzenoid Parallelograms"

INTERNET ELECTRONIC J. MOL. DESIGN 5 (2006) 144-149.

http://www.biochempress.com

482. S. M. Rajtmajer, A. Miličević, N. Trinajstić, M. Randić and D. Vukičević

"On the Complexity of Archimedean Solids"

J. MATH. CHEM. 39 (2006) 119-132.

483. D. Vukičević, D. Veljan and N. Trinajstić

"Thorny Graphs. I. Valence Connectivities"

MATCH - COMMUN. MATH. COMPUT. CHEM. 55 (2006) 73-82.

484. S. Nikolić, A. Miličević and N. Trinajstić

"QSPR Study of Polarographic Half-Wave Reduction Potentials of Benzenoid

Hydrocarbons"

CROAT. CHEM. ACTA 79 (2006) 155-159.

485. D. Janežič, B. Lučić, S. Nikolić, A. Miličević and N. Trinajstić

"Boiling Points of Alcohols - A Comparative Study"

INTERNET ELECTRONIC J. MOL. DESIGN 5 (2006) 192-200.

http://www.biochempress.com

486. A. Miličević S Nikolić and N. Trinajstić

"Toxicity of Aliphatic Ethers: A Comparative Study"

MOLECULAR DIVERSITY 10 (2006) 95-99.

487. I. Gutman, S. Radenković, N. Trinajstić and A. Vodopivec

"On the Relation between $\pi$-Electron Energy and Topological Resonance Energy"

Z. NATURFORSCH. 61a (2006) 345-348.

488. D. Vukičević, I. Lukovits and N. Trinajstić

"Counting Kekulé Structures of Benzenoid Parallelograms Containing One Additional

Benzene Ring"

CROAT. CHEM. ACTA 79 (2006) 509-512.

489. D. Amić, D. Davidović-Amić, D. Bešlo, V. Rastija, B. Lučić and N. Trinajstić "SAR and QSAR of the Antioxidant Activity of Flavonoids"

CURRENT MEDICINAL CHEMISTRY 14 (2007) 827-845.

490. D. Janežič, B. Lučić, A. Miličević, S. Nikolić, N. Trinajstić and D. Vukičević "Hosoya Matrices as the Numerical Realization of Graphical Matrices and Derived Structural Descriptors"

CROAT. CHEM. ACTA 80 (2007) 271-276. 
491. D. Vukičević, B. Zhou and N. Trinajstić

"Altered Wiener Indies of Thorn Trees"

CROAT. CHEM. ACTA 80 (2007) 283-285.

492. D. Vukičević and N. Trinajstić

"On the Anti-forcing Number of Benzenoids"

J. MATH. CHEM. 42 (2007) 575-583.

493. B. Zhou and N. Trinajstić

"On the Largest Eigenvalue of the Distance Matrix of a Connected Graph"

CHEM. PHYS. LETT. 447 (2007) 384-387.

494. B. Zhou and N. Trinajstić

"Further Results on the Largest Eigenvalue of the Distance Matrix and Some Distance-Based

Matrices of Connected (Molecular) Graphs"

INTERNET ELECTRONIC J. MOL. DESIGN 6 (2007) 375-384.

http://www.biochempress.com

495. D. Janežič, A. Miličević, S. Nikolić, N. Trinajstić and D. Vukičević

"Zagreb Indices: Extension to Weighted Graphs Representing Molecules Containing Heteroatoms" CROAT. CHEM. ACTA 80 (2007) 541-545.

496. N. Trinajstić and D. Vukičević

"Mathematical Studies of Kekulé Structures"

STRUCT. CHEM. 18 (2007) 807-812.

497. B. Zhou and N. Trinajstić

"Maximum Eigenvalues of the Reciprocal Distance Matrix and the Reverse Wiener Number"

INT. J. QUANTUM CHEM. 108 (2008) 858-864.

498. D. Vukičević and N. Trinajstić

"On the Anti-Kekulé Number and Anti Forcing Number of Cata-Condensed Benzenoids"

J. MATH. CHEM. 43 (2008) 719-726.

499. D. Vukičević, S. M. Rajtmajer and N. Trinajstić

"Trees with Maximal Second Zagreb Index and Prescribed Number of Vertices of the Given Degree"

MATCH COMMUN. MATH. COMPUT. CHEM. 60 (2008) 65-70.

500. B. Zhou and N. Trinajstić

"A note on Kirchhoff Index"

CHEM. PHYS. LETT. 455 (2008) 120-123.

501. B. Zhou and N. Trinajstić

"Bounds on the Balaban Index"

CROAT. CHEM. ACTA 81 (2008) 319-323.

502. F. Wei, B. Zhou and N. Trinajstić

"Minimal Spectrum-Sums of Bipartite Graphs with Exactly Two Vertex-Disjoint Cycles"

CROAT. CHEM. ACTA 81 (2008) 363-367. 
503. B. Zhou and N. Trinajstić

"On Reciprocal Molecular Topological Index"

J. MATH. CHEM. 44 (2008) 235-243.

504. B. Zhou, X. Cai and N. Trinajstić

"On Harary Index"

J. MATH. CHEM. 44 (2008) 611-618.

505. B. Zhou, Z. Du and N. Trinajstić

"Harary Index of Landscape Graphs"

INT. J. CHEM. MODEL. 1 (2008) 35-44.

506. B. Lučić, S. Nikolić and N. Trinajstić

"Distance-Related Molecular Descriptors"

INTERNET ELECTRONIC J. MOL. DESIGN 7 (2008) 195-206.

http://www.biochempress.com

507. D. Vukičević, S. Nikolić and N. Trinajstić

"On the Path-Zagreb Matrix"

J. MATH. CHEM. 45 (2009) 538-543.

508. D. Amić, B. Lučić, G. Kovačević and N. Trinajstić

"Bond Dissociation Enthalpies Calculated by the PM3 Method Confirm Activity Cliffs in Radical Scavenging of Flavonoids"

MOL. DIVERSITY 13 (2009) 27-36; erratum 13 (2009) 37.

509. B. Zhou and N. Trinajstić

"On Resistance-Distance and Kirchhoff Index"

J. MATH. CHEM. 46 (2009) 283-289.

510. B. Zhou, X. Cai and N. Trinajstić

"On Reciprocal Complementary Wiener Index"

DISCR. APPL. MATH. 157 (2009) 1628-1633.

511. B. Lučić, N. Trinajstić and B. Zhou

"Comparison between the Sum-connectivity and Product-connectivity Indices for Benzenoid Hydrocarbons"

CHEM. PHYS. LETT. 475 (2009) 146-148.

512. Z. Du, B. Zhou and N. Trinajstić

"On Randić Indices of Chemical Trees and Chemical Unicyclic Graphs"

MATCH COMMUN. MATH. COMPUT. CHEM. 62 (2009) 131-142.

513. B. Zhou and N. Trinajstić

"The Kirchhoff Index and the Matching Number"

INT. J. QUANTUM CHEM. 109 (2009) 2978-2981.

514. B. Zhou and N. Trinajstić

"On Reciprocal and Reverse Balaban Indices"

CROAT. CHEM. ACTA 82 (2009) 537-541. 
515. B. Zhou and N. Trinajstić

"On Extended Connectivity Indices"

J. MATH. CHEM. 46 (2009) 1172-1180.

516. B. Zhou and N. Trinajstić

"On a Novel Connectivity Index"

J. MATH. CHEM. 46 (2009) 1252-1270.

517. K. C. Das, B. Zhou and N. Trinajstić

"Bounds on Harary Index"

J. MATH. CHEM. 46 (2009) 1369-1376.

518. N. Trinajstić, and B. Zhou

"Estrada Index of Bipartite Graphs"

INT. J. CHEM. MODEL. 1 (2009) 387-394.

519. B. Zhou, Y. Yang and N. Trinajstić

"On Reciprocal Reverse Wiener Index"

J. MATH. CHEM. 47 (2010) 201-209.

520. B. Zhou and N. Trinajstić

"On General Sum-Connectivity Index"

J. MATH. CHEM. 47 (2010) 210-218.

521. B. Zhou and N. Trinajstić

"On Reverse Degree Distance"

J. MATH. CHEM. 47 (2010) 268-275.

522. Y. Yuan, B. Zhou and N. Trinajstić

"On Geometric-Arithmetic Index"

J. MATH. CHEM. 47 (2010) 833-841.

523. Z. Du, B. Zhou and N. Trinajstić

"Minimum Sum-Connectivity Indices of Trees and Unicyclic Graphs of a

Given Matching Number"

J. MATH. CHEM. 47 (2010) 842-855.

524. B. Zhou and N. Trinajstić

"Mathematical Properties of Molecular Descriptors Based on Distances"

CROAT. CHEM. ACTA 83 (2010) 227-242.

525. K. C. Das and N. Trinajstić

"Comprison Between the First Geometric-Arithmetic Index and Atom-Bond Connectivity Index"

CHEM. PHYS. LETT. 497 (2010) 149-151.

526. R. Xing, B. Zhou and N. Trinajstić

"Sum-Connectivity Index of Molecular Trees"

J. MATH. CHEM. 48 (2010) 583-591. 
527. B. Zhou and N. Trinajstić

"Minimun General Sum-Connectivity Index of Unicyclic Graphs"

J. MATH. CHEM. 48 (2010) 697-703.

528. B. Zhou and N. Trinajstić

"Some Properties of the Reformulated Zagreb Indices"

J. MATH. CHEM. 48 (2010) 714-719.

529. B. Zhou and N. Trinajstić

"On Sum-Connectivity Matrix and Sum-Connectivity Energy of (Molecular) Graphs" ACTA CHIM. SLOVEN. 57 (2010) 518-523.

530. D. Vukičević, N. Trinajstić, S. Nikolić, B. Lučić and B. Zhou

"Master Connectivity Index and Master Connectivity Polynomial"

CURRENT COMPUTER-AIDED DRUG DESIGN 6 (2010) 235-239.

531. D. Vukičević and N. Trinajstić

"Bond-Additive Modeling. 3. Comparison between the Product-connectivity Index and Sumconnectivity Index"

CROAT. CHEM. ACTA 83 (2010) 349-351.

532. Z. Du, B. Zhou and N. Trinajstić

"On the General Sum-Connectivity Index of Trees"

APPL. MATH. LETT. 24 (2011) 402-405

536. K. Xu and N. Trinajstić

"Hyper-Wiener and Harary Indices of Graphs with Cut Edges"

UTILITAS MATHEMATICA 84 (2011) 153-163.

537. S. Wang, B. Zhou and N. Trinajstić

"On the sum-connectivity index"

FILOMAT 25 (2011) 29-42.

538. S. Feretić and N. Trinajstić

"The Area Generating Function for Simple-2-column Polyominoes with Hexagonal Cells"

INT. J. CHEM. MODEL. 3 (2011) 115-129.

539. B. Zhou and N. Trinajstić

"On Altered Wiener Indices of Trees and Molecular Trees"

INT. J. CHEM. MODEL. 3 (2011) 437-447.

540. K. C. Das and N. Trinajstić

"Relationship Between the Eccentric Connectivity Index and Zagreb Indices"

COMPUT. MATH. APPL. 62 (2011) 1758-1764.

541. Z. Du, B. Zhou and N. Trinajstić

"On Geometric-Arithmetic Indices of (Molecular) Trees, Unicyclic Graphs and Bicyclic Graphs"

MATCH COMMUN. MATH. COMPUT. CHEM. 66 (2011) 681-697. 
542. R. Xing, B. Zhou and N. Trinajstić

"On the Zagreb Eccentricity Indices"

CROAT. CHEM. ACTA 84 (2011) 493-497.

543. H. Dong, B. Zhou and N. Trinajstić

"A novel version of the edge-Szeged index"

CROAT. CHEM. ACTA 84 (2011) 543-545.

544. W. Luo, B. Zhou, N. Trinajstić and Y. Du

"Reverse Wiener Indices of Graphs with Exactly Two Cycles"

UTILITAS MATHEMATICA 88 (2012) 189-202.

545. K. C. Das and N. Trinajstić

"Comparison Between the Geometric-arithmetic Indices"

CROAT. CHEM. ACTA 85 (2012) 353-357.

546. Z. Du, B. Zhou and N. Trinajstić

"Extremal Properties of the Zagreb Eccentricity Indices"

CROAT. CHEM. ACTA 85 (2012) 359-362.

547. B. Zhou and N. Trinajstić

"Relations Between the Product- and Sum-connectivity Indices"

CROAT. CHEM. ACTA 85 (2012) 363-365.

548. B. Lučić, I. Sović, J. Batista, K. Skala, D. Plavšić, D. Vikić-Topić, D. Bešlo, S. Nikolić and N. Trinajstić

"The Sum-Connectivity Index - An Additive Variant of the Randić Connectivity Index"

CURRENT COMPUTER-AIDED DRUG DESIGN 9 (2013) 184-194.

549. B. Lučić, I. Sović, D. Bešlo, D. Plavšić, D. Vikić-Topić and N. Trinajstić On the Novel Balaban-Like and Balaban-Detour-Like Molecular Descriptors INT. J. CHEM. MODEL. 5 (2013) 277-294.

550. K. C. Das, H-u. Jeon and N. Trinajstić

Comparison between the Wiener index and the Zagreb indices and the eccentric connectivity index for trees

DISCRETE APPL. MATH. 171 (2014) 35-41. 


\section{Nenad Trinajstić}

\section{Books}

1. N. Trinajstić

"Molekularne orbitale u kemiji" (Molecular Orbitals in Chemistry)

Školska knjiga, Zagreb, 1974, 120 str.

2. A. Graovac, I. Gutman, N. Trinajstić

"Topological Approach to the Chemistry of Conjugated Molecules"

Springer-Verlag, Berlin, 1977, 123 str.

3. L. Klasinc, Z. B. Maksić, N. Trinajstić

"Simetrija molekula" (Symmetry of Molecules)

Školska knjiga, Zagreb, 1979, 131 str.

4. N. Trinajstić

"Chemical Graph Theory", Volume I

Chemical Rubber Company (CRC) Press, Boca Raton, Florida, 1983, 147 str.

5. N. Trinajstić

"Chemical Graph Theory", Volume II

Chemical Rubber Company (CRC) Press, Boca Raton, Florida, 1983, 166 str.

6. N. Trinajstić

"Orbitalet moleculare në kimi" (revised translation into Albanian language of "Molecular Orbitals in Chemistry)

Sveučilište, Prishtinë, 1984, 120 str. .

7. J. V. Knop, W. R. Müller, K. Szymanski, N. Trinajstić

"Computer Generation of Certain Classes of Molecules"

SKTH/Kemija u industriji, Zagreb, 1985, 253 str.

8. N. Trinajstić, S. Nikolić, J. V. Knop, W. R. Müller, K. Szymanski

"Computational Chemical Graph Theory: Characterization, Enumeration and Generation of Chemical Structures by Computer Methods"

Simon \& Schuster/Horwood, Chichester, 1991, 356 str.

9. N. Trinajstić

"Chemical Graph Theory", second revised edition

CRC Press, Boca Raton, Florida, 1992, 322 str.

10. N. Trinajstić

"Ogledi o znanosti i znanstvenicima" (Essays on Science and Scientists)

Matica hrvatska, Zagreb, 1998, 188 str.

11. N. Trinajstić

"100 hrvatskih kemičara" (100 Croatian Chemists)

Školska knjiga, Zagreb, 2002. 
12. D. Janežič, A. Miličević, S. Nikolić, N. Trinajstić

"Graph-Theoretical Matrices in Chemistry"

University of Kragujevac, Kragujevac, 2007.

13. S. Paušek-Baždar, N. Trinjastić

"Hrvatska kemija u XX. stoljeću - Ljudi i događaji"

Školska knjiga i HAZU, Zagreb, 2014.

14. K. Xu, K. C. Das, N. Trinajstić

"The Harary Index of a Graph"

Springer, Berlin, 2015.

15. D. Janežič, A. Miličević, S. Nikolić, N. Trinajstić

"Graph-Theoretical Matrices in Chemistry"

CRC, Boca Raton, FL, 2015., seond enlarged and corrected edition

16. N. Trinajstić

"Život u znanosti - Uspomene iz nepovrata"

HAZU, Zagreb, 2016.

17. B. Lučić, A. Miličević, N. Trinajstić

"The Zagreb Indices: Developments, Properties and Applications"

In press 
Nenad Trinajstić

\section{Editorial work}

1. N. Trinajstić (Editor)

"Mathematics and Computational Concepts in Chemistry"

Horwood/Wiley, New York, 1986, str. 365.

2. D. J. Klein and N. Trinajstić (Editors)

"Valence Bond Theory and Chemical Structure"

Elsevier, New York, 1990, str. 629. 


\section{Nenad Trinajstić}

\section{Professional papers}

1. I. Gutman i N. Trinajstić

"Primjena teorije grafova u kemiji. I. Elementi teorije grafova"

KEM. IND. (Zagreb) 22, 75-79 (1973).

2. I. Gutman i N. Trinajstić

"Primjena teorije grafova u kemiji. II. Veza između teorije molekularnih orbitala i teorije grafova"

KEM. IND. (Zagreb) 22, 237-240 (1973).

3. I. Gutman i N. Trinajstić

"Primjena teorije grafova u kemiji. III. Alternantni ugljikovodici i njihova svojstva"

KEM. IND. (Zagreb) 23, 329-333 (1974).

4. I. Gutman i N. Trinajstić

"Primjena teorije grafova u kemiji. IV. Predviđanje stabilnosti velikih policikličkih konjugiranih molekula"

KEM. IND. (Zagreb) 23, 381-386 (1974).

5. I. Gutman i N. Trinajstić

"Primjena teorije grafova u kemiji. V. Pravilo modula 4"

KEM. IND. (Zagreb) 23, 641-645 (1974).

6. I. Gutman and N. Trinajstić

"The Modulo 4 Rule"

SCIENTIA YUG. 1, 1-2 (1974).

7. I. Gutman i N. Trinajstić

"Primjena teorije grafova u kemiji. VI. Predviđanje termodinamičkih svojstava alkana"

KEM. IND. (Zagreb) 24, 25-29 (1975).

8. J. V. Knop, I. Gutman, i N. Trinajstić

"Primjena teorije grafova u kemiji. VII. Prikazivanje kemijskih struktura u dokumentaciji" KEM. IND. (Zagreb) 24, 505-510 (1975).

9. N. Trinajstić

"Od prirodoslovca do kemičara, od kemičara do prirodoslovca",

"Simpozij prirodne znanosti i njihovo značenje u suvremenom društvu"

Hrvatsko prirodoslovno društvo, Zagreb 1975, str. 49-50.

10. N. Trinajstić i T. Živković

"A gráfemélet az elméleti kémiában"

KÉMIAI KÖZLEMÉNYEK (Budapesti) 44, 460-466 (1975).

11. A. Graovac, I. Gutman, i N. Trinajstić

Primjena teorije grafova u kemiji. VIII. Möbiusove strukture"

KEM. IND. (Zagreb) 25, 229-233 (1976). 
12. N. Trinajstić

"Elektronska struktura benzena"

PRIRODA 65, 39-41 (1976).

13. N. Trinajstić

"Prognoziranje kemijske reaktivnosti"

KEM. IND. (Zagreb) 25, 339-343 (1976).

14. N. Trinajstić

"Profesor Vladimir Prelog, sudobitnik Nobelove nagrade za kemiju 1975"

KEM. IND. (Zagreb) 25, 295-298 (1976).

15. N. Trinajstić

"Some Graph-Theoretical Results of the Zagreb Group in 1975"

MATCH COMMUN. MATH. COMPUT. CHEM. (Mülheim/Ruhr) 2, 3-15 (1976).

16. M. Milun i N. Trinajstić

"Teorija aromatičnosti"

KEM. IND. (Zagreb) 25, 559-570 1976).

17. N. Trinajstić i R. Trinajstić

"Prirodni spojevi. O strukturnim svojstvima porfirina"

PRIRODA 65, 132-133 (1976).

18. H. Bilinski, M. Marković, i N. Trinajstić

"Živa u okolišu. I. "

KEM. IND. (Zagreb) 25, 521-527 (1976).

19. B. Džonova-Jerman-Blažič, N. Trinajstić, i B. Mohar

"Računalniško generiranje acikličnega polinoma molekularnih grafov"

INFORMATICA 77, 6233 1-4 (1977).

20. M. Protić i N. Trinajstić

"Prirodni spojevi. II. Alkaloidi"

PRIRODA 65, 268-270 (1976).

21. Z. Bačić, N. Trinajstić i V. Žganec

"O metadonu i opijatskim analgeticima"

KEM. IND. (Zagreb) 26, 639-645 (1977).

22. K. Horvatić i N. Trinajstić

"Matematička kemija. Primjena teorije skupova u kemiji"

KEM. IND. (Zagreb) 27, 127-135 (1978).

23. N. Trinajstić

"Na granici izmeðu bioorganske kemije i biokemije"

KEM. IND. (Zagreb) 27, 160-162 (1978).

24. E. Rachin, M. Milun and N. Trinajstić

"PCILO Conformational Analysis of Phenylimidazoles"

IZVESTIJA PO HIMIJA (Sofija) 11, 313-318 (1978). 
25. H. Bilinski i N. Trinajstić

"Živa u okolišu. II. O metil-živi"

KEM. IND. (Zagreb) 28, 59-65 (1979).

26. A. Sabljić, N. Trinajstić i J. V. Knop

"O molekularno-orbitalnoj teoriji u kvantnoj biokemiji i kvantnoj farmakologiji"

KEM. IND. (Zagreb) 28, 113-122 (1979).

27. A. Sabljić i N. Trinajstić

"Odnos strukture i biološke aktivnosti"

KEM. IND. (Zagreb) 28, 467-477 (1979).

28. N. Trinajstić, G. Protić, V. Švob i Đ. Deur-Šiftar

"Izračunavanje indeksa zadržavanja u plinskoj kromatografiji pomoću strukturnih faktora.

Alkil-benzeni"

KEM. IND. (Zagreb) 28, 527-537 (1979).

29. H. Bilinski, N. Trinajstić i M. Zelić

"Živa u okolišu. III. O akumulaciji žive i metil-žive u organizmima"

KEM. IND. (Zagreb) 29, 53-58 (1980).

30. B. Džonova-Jerman-Blažič i N. Trinajstić

"Topološki modeli za predstavitev rezonančnih oblik molekulskih struktur"

Zbornik radova "BIOMEDICINSKA KIBERNETIKA", Skopje 1980, str. 136-149.

31. P. Ilić i N. Trinajstić

"Neklasična aromatičnost. Aromatičnost konjugiranih iona"

KEM. IND. (Zagreb) 29, 417-423 (1980).

32. B. Džonova-Jerman-Blažič i N. Trinajstić

"Kemijski informacijski sistemi. II. Algoritmi za obravnavo in obdelavo kemijsko-strukturnih informacij"

INFORMATICA 80, 47-54 (1980).

33. N. Trinajstić

"Kemija"

TEHNIČKA ENCIKLOPEDIJA, Leksikografski zavod, Zagreb 1980, Vol. 7, str. 1-33.

34. W. Müller, N. Trinajstić, and J. V. Knop

"GEPORT - Generation, Enumeration, and Plotting of Rooted Trees"

QCPE BULL. 1, 15 (1981).

35. N. Trinajstić

"Noviji rezultati Zagrebačke grupe u kemijskoj teoriji crteža, 1977-1981"

KEM. IND. (Zagreb) 30, 387-397 (1981).

36. N. Trinajstić

"Nobelove nagrade za kemiju godine 1981. Teorijska kemija"

PRIRODA 70, 101-102 (1981). 
37. B. Ruščić i N. Trinajstić

"Molekula"

TEHNIČKA ENCIKLOPEDIJA, Leksikografski zavod, Zagreb 1982, Vol. 8, 627-643.

38. G. Q. Jashari dhe N. Trinajstić

"Teorija e Grafave dhe Energjia Rezonante Topologjike e Molekuleve Benzenoide"

BULL. CHEM. TECHN. KOSOVO 2, 193-198 (1982).

39. N. Trinajstić

"O prirodi kemijske strukture"

KEM. IND. (Zagreb) 33, 311-320 (1984).

40. N. Trinajstić

"Povratak povjerenja u teoriju valentnih struktura"

KEM. IND. (Zagreb) 33, 499-514 (1984).

41. J. V. Knop, K. Szymanski, N. Trinajstić

"Future Developments in Computer Architecture"

INFORMATICA 1, 48-56 (1984).

42. J. V. Knop, K. Szymanski, G. Jashari and N. Trinajstić

"Computer-Assisted Generation of Aza-Benzenoids"

BULL. CHEM. TECHN. KOSOVO 3, 7-18 (1984).

43. D. Kasum i N. Trinajstić

"Matematička kemija. II. O Polyinom teoremu"

34, 245-251 (1985).

44. G. Jashari, A Veseli, A. Graovac, dhe N. Trinajstić

"Shqyrtimi i spektreve të largësisë së disa llojeve të grafeve molekularë (On the Distance Spectra of Some Classes of Molecular Graphs)"

BULL. CHEM. TECHN. KOSOVO 4, 177-242 (1985).

45. K. Humski, V. Imper, i N. Trinajstić

"O stereizometriji i kiralnosti"

KEM. IND. (Zagreb) 35, 151-160 (1986).

46. D. J. Klein and N. Trinajstić

"On the Chemical Structure-Biological Activity Relationships"

in: The First Yugoslav Symposium on Molecular Sciences "Modelling of Structure and Properties of Molecules and Materials"

Zagreb 1986, pp. 113-120.

47. N. Trinajstić

"Znanstveni rad Vladimira Preloga"

PRIRODA 75, 7-8 (1986).

48. N. Trinajstić i T. Tóth

"Interakcija korisnika i sekundarnih izvora informacija prikazana na primjeru Chemical Abstract Sevice-a"

KEM. IND. (Zagreb) 35, 527-550 (1986). 
49. A. Sabljić and N. Trinajstić

"Quantitative Structure-Activity Relationships (QSAR) in Drug Research"

ACTA PHARM. JUGOSL. 36, 79-80 (1986).

50. S. Nikolić i N. Trinajstić

"Ugljikova molekula: poput nogometne lopte"

PRIRODA 75, 115-117 (1986/87).

51. N. Trinajstić, J. V. Knop, W. R. Müller and K. Szymanski

"Chemical Graph Theory. VIII. On the 2-factors of Polyhexes"

KEM. IND. (Zagreb) 35, 671-674 (1986).

52. S. Nikolić i N. Trinajstić

"O kavezastoj ugljikovoj molekuli $\mathrm{C}_{60}$ "

KEM. IND. (Zagreb) 36, 107-111 (1987).

53. A. Jurić, D. Kitan, M. Kuleš, M. Trkovnik,i N. Trinajstić

"O aromatičnosti kumarina i nekih njegovih derivata i o odnosu između p-elektronskog naboja i protonskog pomaka u njihovim NMR spektrima"

KEM. IND. (Zagreb) 36, 233-238 (1987).

54. N. Trinajstić

"Graphs as General Models"

in: Research, Science and Technology

Edited by V. Muljević and G. Macesich

Center for Yugoslav-American Studies, Tallahassee, Florida, 1987, pp. 168-185.

55. N. Trinajstić

"Informacija i vrijednost informacije"

POLITIČKA MISAO 24, 12-15 (1987).

56. N. Trinajstić, S. Nikolić i D. Horvat

"O prirodi kemijske strukture"

PRIRODA 76, 51-53 (1987/88).

57. N. Trinajstić, S. Nikolić i D. Horvat

"Matematički modeli strukture molekula"

KEM. IND. (Zagreb) 36, 493-502 (1987).

58. N. Trinajstić

"Teorija na grafite i molekulnite orbitali"

$\mathrm{u}$ : "Teorija na grafite i priloženieto i v himijata"

uredili N. Tyutyulkov i D. Bonchev

Nauka i iskustvo, Sofija 1987, treće poglavlje, str. 86-120.

59. S. Nikolić i N. Trinajstić

"O velikim kavezastim molekulama"

ACTA CHIM. KOSOVICA 7, 75-92 (1987). 
60. N. Trinajstić

"How I Met Michael Dewar"

in: "Michael J. S. Dewar - A Group Memoir"

Edited by Nathan L. Bauld

Austin, 1988, 135-138.

61. A. Sabljić and N. Trinajstić

"A Formula for Rating Scientists"

PERIOD. BIOL. 90, 397-399 (1988).

62. N. Trinajstić

"O prirodi kemijske strukture"

SCI. YUGOSL. 14, 119-124 (1988).

63. N. Trinajstić, S. Nikolić, and S. Carter

"QSAR: Theory and Application"

KEM. IND. (Zagreb) 38, 469-484 (1989).

64. N. Trinajstić

" 'If you want to be leader, think!' "

J. MOL. STRUCT. (THEOCHEM) 200, 219-224 (1989).

65. D. J. Klein and N. Trinajstić

"An Introduction"

Valence Bond Theory and Chemical Structure

Edited by D. J. Klein and N. Trinajstić

Elsevier, Amsterdam, 1990, pp. 1-10

66. D. Amić i N. Trinajstić

"O reaktivnosti i stabilnosti flavilijevog kromofornog sustava"

KEM. IND. (Zagreb) 41, 345-359 (1992).

67. N. Trinajstić

"Božo Težak (1907-1980)"

HRVATSKI ZNANSTVENI ZBORNIK 2, 27-49 (1993).

68. N. Trinajstić

"Uvodno slovo"

SPOMENICA o devedesetoj obljetnici postojanja Agrikulturnog-kemijskog zavoda u Križevcima

Poljoprivredni institut i Ogranak Matice hrvatske, Križevci, 1993, str. 1-3.

69. N. Trinajstić

"Zdenko Majerski (1937-1988) - rani odlazak tihog čovjeka"

RADOVI Leksikografskog zavoda "Miroslav Krleža" 3, 115-121 (1993).

70. N. Trinajstić

"On the Evaluation of the Quality of Scientific Research"

ENCYCLOPAEDIA MODERNA 14, 256-261 (1993). 
71. N. Trinajstić

"Experimental and Theoretical Research in the Natural Sciences"

ENCYCLOPAEDIA MODERNA 14, 359-360 (1993).

72. N. Trinajstić

"Hoffmann, Roald (1937 -) - Primijenjena teorijska kemija"

u: "VELIKANI NAŠE EPOHE"

Uredio Ratko Vince

Hrvatski radio, Zagreb 1994, 317-322.

73. M. Pavlović, A. Alebić-Juretić, L. Klasinc, N. Trinajstić, R. Turk i N. Kezele

"Čovjek, okoliš i ozon"

ARHIV ZA HIGIJENU RADA I TOKSIKOLOGIJU 45, 275-284 (1994).

74. N. Trinajstić

"Kemija - moćna znanost budućnosti"

HRVATSKI ZNANSTVENI ZBORNIK 3, 65-73 (1994).

75. N. Trinajstić

"My Twenty Years of Cooperation with American Scientists in Theoretical Chemistry"

USA-Croatia Scientific Cooperation 1963-1993

Edited by V. Paar

Školska knjiga, Zagreb, 1995, pp. 317-322.

76. N. Trinajstić

"Mladen Deželić - zaboravljeni hrvatski kemičar"

POLIMERI 16, 167-170 (1995).

77. N. Trinajstić

"O filozofiji prirodnih znanosti"

POLIMERI 16, 275-279 (1995).

78. N. Trinajstić

"Kemija - moćna znanost budućnosti"

KEM. IND. (Zagreb) 44, 519-524 (1995).

79. N. Trinajstić

"Mladen Deželić - zaboravljeni hrvatski kemičar"

PRIRODA 86, 28-31 (1996).

80. N. Trinajstić i Đ. Težak

"Život i djelo Mladena Deželića- zmaja Klokočkog IV. "

u: Znameniti prirodoslovci članovi Družbe 'Braća Hrvatskog Zmaja'

Urednik Alojz Getliher

Družba "Braća Hrvatskog Zmaja" i Školska kn jiga, Zagreb, 1996, str. 14-27.

81 N. Trinajstić

"Institut Rugjer Bošković i Prirodoslovno-matematički fakultet"

POLIMERI 17, 98-100 (1996). 
82. N. Trinajstić

"Hrvatski velikani znanosti" - predgovor

u: Katalozima izložbe "Znanost u Hrvata: prirodoslovlje i njegova primjena"

Urednica Greta Pifat-Mrzljak

Muzejsko-galerijski centar, Zagreb, 1996, str. 366-368. (prvi dio) i 16-18 (drugi dio).

83. B. Lučić, N. Trinajstić i D. Juretić

"Od sekvencije do konformacije proteina. I. "

POLIMERI 17, 119-128 (1996).

84. N. Trinajstić

"Prelogov znanstveni rad"

RUGJER 1 (\#2), 5-6 (1996).

85. N. Trinajstić

"Uoči sedamdesete obljetnice časopisa 'Croatica Chemica Acta' "

RUGJER 1 (\#4), 16-19 (1996).

86. N. Trinajstić

Ljepota se ipak nagrađuje - Nobelova nagrada za kemiju 1996

POLIMERI 17, 269-270 (1996).

87. S. Paušek-Baždar i N. Trinajstić

"Kratki pregled hrvatske kemije u XX. stoljeću"

RUGJER 2 (\#6), 3-10 (1997).

88. S. Nikolić i N. Trinajstić

"Milutin Cihlar Nehajev kao kemičar"

RUGJER 2 (\#7), 11-12 (1997).

89. N. Trinajstić

"The 70th Anniversary of CROATICA CHEMICA ACTA 1927-1997"

CROAT. CHEM. ACTA 70, I-IV (1997).

90. N. Trinajstić

"Prirodne znanosti i opće dobro"

PRIRODA 87 (\#838), 3 (1997).

91. N. Trinajstić, N. Brničević, M. Herceg i S. Nikolić

"Suvremena anorganska, strukturna i teorijska kemija u Hrvatskoj"

u: Zbornik radova Simpozija o fundamentalnim istraživanjima

urednik: Dubravko Tadić

HAZU, Zagreb, 1997, str. 124-134.

92. I. Piljac, N. Trinajstić i H. Vančik

"Ugljik"

TEHNIČKA ENCIKLOPEDIJA, Leksikografski zavod, Zagreb 1997, Vol. 13, 293-315. 
93. N. Trinajstić i S. Nikolić

"Profesor Milan Randić- znanstvenik nemirnog duha"

u: ISTAKNUTI HRVATSKI ZNANSTVENICI U AMERICI"

urednici: J. Herak i S. Nikolić

Hrvatsko-američko društvo i Matica hrvatska, Zagreb, 1997, str. 1-21.

94. N. Trinajstić

"U spomen - znanstveni rad nobelovca Dr. Sc. Vladimira Preloga

(23. 7. 1906.- 7. 1. 1998.)"

PRIRODA 88 (\#849-850), 6-7 (1998).

95. N. Trinajstić i S. Nikolić

"O broju pet u prirodi, kemiji i drugdje"

POLIMERI 19, 97-98 (1998).

96. N. Trinajstić

"Mnogo vike o ničemu"

POLIMERI 19, 99-100 (1998).

97. N. Trinajstić

"Kako vrednovati znanstveni rad i znanstvenike?"

u: "VIDLJIVA I NEVIDLJIVA AKADEMIJA"

uredio: Darko Polšek

Institut društvenih znanosti IVO PILAR, Zagreb, 1998, str. 101-110.

98. L. Pogliani, M. Randićand N. Trinajstić

"Is Zero Something Rather than Nothing"

KEM. IND. (Zagreb) 47, 387-396 (1998).

99. N. Trinajstić

"Kemija u Hrvatskoj: osvrt na Ružičku i pogled unaprijed"

POLIMERI 19, 216-217 (1998).

100. B. Lučić i N. Trinajstić

"Citiranosti hrvatskih kemičara od početka 1981. do lipnja 1997."

POLIMERI 19, 224 (1998).

101. N. Trinajstić

"Hrvatski časopis za kemiju Croatica Chemica Acta"

SVEUČILIŠNI GLASNIK 44, 89-92 (1998).

102. L. Pogliani, M. Randićand N. Trinajstić

"Much Ado about Nothing - An Introductory Inquiry about Zero"

INT. J. MATH. EDUC. SCI. TECHNOL. 29, 729-744 (1998).

103. B. Lučić i N. Trinajstić

"Citiranosti hrvatskih kemičara od početka 1981. do lipnja 1997. " KEM. IND. (Zagreb) 48, 33 (1999). 
104. S. Nikolić i N. Trinajstić

"Sjećanje na Krešimira Humskoga (1939.-1997.) i

Zdenka Majerskoga (1937.-1988.)"

KEM. IND. (Zagreb) 48, 81-84 (1999).

105. N. Trinajstić

"Božo Težak and Croatica Chemica Acta"

CROAT. CHEM. ACTA 72, A1-A4 (1999).

106. N. Trinajstić

"Dopisivanje s profesorom Vladimirom Prelogom"

KEM. IND. (Zagreb) 48, 151-157 (1999).

107. N. Trinajstić

"Felix Klein's Commemorative Plague in Düsseldorf"

MATH. INTELL. 21, 50 (1999).

108. N. Trinajstić

"Kemija - središnja prirodna znanost"

HRVATSKA REVIJA XLIX, 85-93 (1999).

109. N. Trinajstić

"Dopisivanje s profesorom Vladimirom Prelogom"

GAZOPHYLACIUM IV, 117-124 (1999).

110. S. Nikolić i N. Trinajstić

"Milutin Cihlar Nehajev - hrvatski književnik i kemičar"

HRVATSKA REVIJA XLIX, 582-590 (1999).

111. S. Nikolić i N. Trinajstić

"Milutin Cihlar Nehajev kao kemičar"

KEM. IND. (Zagreb) 49, 111-117 (2000).

112. S. Nikolić i N. Trinajstić

"O znanosti i znanstvenoj metodi"

KEM. IND. (Zagreb) 49, 265-273 (2000).

113. S. Nikolić i N. Trinajstić

"O vremenu i računanju vremena"

GAZOPHYLACIUM V, 82-86 (2000).

114. L. Pogliani, M. Randićand N. Trinajstić

"About One - An Inquiry About the Meaning and Uses of the Number One"

INT. J. MATH. EDUC. SCI. TECHNOL. 31, 811-824 (2000).

115. N. Trinajstić

"Quantum Theory in Chemistry - Early Developments"

KEM. IND. (Zagreb) 50, 421-425 (2001). 
116. N. Trinajstić

"Quantum Chemistry in Croatia - Beginnings"

KEM. IND. (Zagreb) 50, 427-429 (2001).

117. N. Trinajstić

"Smiljko Ašperger - Curriculum Vitae"

CROAT. CHEM. ACTA 74, VII-X (2001).

118. S. Nikolić i N. Trinajstić

"Milutin Cihlar Nehajev - kemičar s doktoratom Sveučilišta u Beču i hrvatski književnik" GAZOPHYLACIUM VI, 33-42 (2001).

119. S. Nikolić and N. Trinajstić

"Milan Randić_ L Life and Work"

CROAT. CHEM. ACTA 75, 319-327 (2002).

120. N. Trinajstić and I. Gutman

"Mathematical Chemistry"

CROAT. CHEM. ACTA 75, 329-356 (2002).

121. D. Amić i N. Trinajstić

"Antioksidacijska aktivnost vina"

GAZOPHYLACIUM VII (2002) 88-93.

122. N. Trinajstić

"Quantum Theory in Chemistry"

in: HUNDRED YEARS OF QUANTUM THEORY

Edited by D. Tadić

Croatian Academy of Sciences and Arts, Zagreb, 2002, pp. 55-65.

123. N. Trinajstić

"O Ružičkinom imenu"

KEM. IND. 52 (2003) 122.

124. N. Trinajstić

"A Life in Science"

INTERNET ELECTRONIC J. MOL. DESIGN 2 (2003) 413-434.

http://www.biochempress.com

125. S. Nikolić and N. Trinajstić

"Complexity of Molecules"

in: PROCEEDINGS OF THE INTERNATIONAL CONFERENCE OF COMPUTATIONAL METHODS IN SCIENCES AND ENGINEERING 2003

Edited by T. E. Simos

World Scientific, Singapore, 2003, pp. 454-456.

126. N. Trinajstić, S. Turina i J. Varljen

"Želimir Procházka (1921.-2003.) - hrvatski đak, češki znanstvenik"

KEM. IND. 52 (2003) 527-529. 
127. N. Trinajstić

"Zanimljivosti o broju 13"

GAZOPHYLACIUM VIII (2003) 23-26.

128. N. Trinajstić

Virtualni razgovor s Vladimirom Katovićem

GLASNIK AMACIZ-a 31 (2003) 17-18.

129. N. Trinajstić

"Kako se zvao Ružička"

PRIRODA 94 (2004) 19

130. N. Trinajstić

Krešimir Balenović (1914.-2003.) - životni put,

u: KREŠIMIR BALENOVIĆ (1914.-2003.)

uredio N. Trinajstić,

Spomenica preminulim akademicima, HAZU, Zagreb, 2004., svezak 120, str. 9-16.

131. N. Trinajstić

"Dr. Krešimir Balenović - sveučilišni profesor i akademik"

LIČKA REVIJA 5, 46-39 (2005).

132. N. Trinajstić

"More on Felix Klein in Düsseldorf"

MATH. INTELL. 27 (3) (2005) 4-5.

133. S Nikolić, A. Miličević and N. Trinajstić

"Graphical Matrices in Chemistry"

WSEAS TRANSACTIONS ON INFORMATION SCIENCE \& APPLICATIONS 2 (issue 11), 1739-1742 (2005)

134. S. Nikolić i N. Trinajstić

"Leopold Ružička - prvi Hrvat dobitnik Nobelove nagrade"

u: UGLEDNI HRVATSKI ZNANSTVENICI U SVIJETU

urednik: Janko Herak

Hrvatsko-američko društvo i Hrvatska matica iseljenika, Zagreb, 2005.

Hrvatski tekst - str. 110-118

Engleski prijevod - str. 238-246.

135. N. Trinajstić

"Sjećanje na Akademika Miroslava Karšulina"

u: SPOMENICI POSVEĆENOJ MIROSLAVU KARŠULINU (1904.-1984.)

urednik: N. Trinajstić

HAZU, Zagreb, 2005, str. 7-12.

136. N. Trinajstić

"Mladen Deželić (1900.-1989.) - Zmaj Klokočki IV.: Znanstveni rad i sveučilišna karijera u

Zagrebu"

u: MLADEN DEŽELIĆ (3. I. 1900. - 28. XI. 1989.)

urednik: Žarko Dadić

Družba "Braća Hrvatskoga Zmaja", Zagreb, 2005, str. 1123. 
137. B. Pavlović i N. Trinajstić

"O simetriji i asimetriji u književnosti"

$\mathrm{u}$ : LJEPOTA RIJEČI

urednik: Josip Pandurić

Disput d. o. o., Zagreb. 2005., str. 97-149.

138. N. Trinajstić

"Vladimir Prelog (1906.-1998.)"

HRVATSKO SLOVO 11 (20. 12. 2005.) 15.

139. N. Trinajstić

"O nekim zanimljivim rezultatima postignutim u Hrvatskoj u području matematičke kemije" KEM. IND. 55 (2006) 223-227.

140. S. Paušek-Baždar i N. Trinajstić

"Hrvatska kemija u 19. stoljeću"

KEM. IND. 55 (2006) 333-339.

141. N. Trinajstić

"Sjećanje na godine studija 1956.-1960. "

GLASNIK 37 (2006) 19-21.

142. N. Trinajstić

"Vladimir Prelog - treći Hrvat dobitnik Nobelove nagrade"

u: SPOMENICI POSVEĆENOJ VLADIMIRU PRELOGU (1906.-1998.)

urednik: K. Ilakovac

HAZU, Zagreb, 2006, str. 11-23.

143. N. Trinajstić

"Leopold Ružička (1887.-1978.) - prvi Hrvat dobitnik Nobelove nagrade"

u: PERIVOJ HRVATSKIH VELIKANA - RONDEL UČENIKA GIMNAZIJE U OSIJEKU urednici: A. Tucak, A. Mutnjaković, G. Kralik

Družba "Braća Hrvatskoga Zmaja" - Zmajski stol u Osijeku, Osijek, 2007., 44-52.

144. N. Trinajstić

"Leopold Ružička (1887.-1976.) - the First Croat Nobel Prizewinner"

in: THE PUBLIC GARDEN OF CROATIAN GREAT MEN - THE ROUNDEL OF OSIJEK GRAMMAR SCHOOL STUDENTS"

Editors: A. Tucak, A. Mutnjaković, G. Kralik

The Brothers of the Croatin Dragon Society - Dragon Seat in Osijek, Osijek, 2007, 122-123.

145. N. Trinajstić

"Kako vrednovati znanstvenike?"

KEM. IND. 56 (2007) 61-62.

146. N. Trinajstić

"Manje znani hrvatski kemičari. I. Božidar Rogina"

KEM. IND. 56 (2007) 345-351. 
147. N. Trinajstić

"Rani dani Instituta Rugjera Boškovića i Profesor Božo Težak"

u: PROFESOR BOŽO TEŽAK, LUČONOŠA ZNANOSTI

urednica: Gjurgjica Težak

Hrvatska sveučilišna naklada, Zagreb, 2007., 97-102.

148. N. Trinajstić i S. Paušek-Baždar

"Hrvatska kemija u XX. stoljeću. I. dio. Razdoblje od 1901. do 8. svibnja 1945. "

KEM. IND. 56 (2007) 403-416.

149. N. Trinajstić

"Pogled na hrvatsku kemiju kroz skupove kemičara i kemijskih inženjera (1969.-2007.)"

KEM. IND. 56 (2007) 501-509.

150. S. Nikolić i N. Trinajstić

"Milutin Cihlar Nehajev - hrvatski književnik i kemičar"

SENJSKI ZBORNIK 33 (2006/2007) 271-292.

151. N. Trinajstić

"Znanstveni skupovi Hrvatski prirodoslovci"

KEM. IND. 56 (2007) 610-611.

152. N. Trinajstić

"Leopold Ružička (1887.-1976.) - Vukovarac i prvi Hrvat dobitnik Nobelove nagrade"

VUKOVARSKI ZBORNIK 2 (2007) 155-168.

153. N. Trinajstić

"Hirschov indeks $h$ nekih sadašnjih i bivših članica i članova Grupe za teorijsku kemiju Instituta "RugjerBošković"

KEM. IND. 57 (2008) 465-479.

154. N. Trinajstić, N. Raos, S. Paušek-Baždar i D. Škare

"Hrvatska kemija u XX. stoljeću. IV. Hrvatski kemijski časopisi"

KEM. IND. 57 (2008) 447-448.

155. B. Lučić, S. Nikolić, N. Trinajstić

"Távolságfüggő molekuláris deszkriptorok"

MAGYAR KEMIAI FOLYÓIRAT - ÖSSZEFOGLALÓ KÖZLEMÉNYEK

(Budapesti) 114, 171-175 (2008).

156. N. Trinajstić

"O životnome putu i znanstvenome djelu Leopolda Ružičke, prvoga Hrvata dobitnika

Nobelove nagrade"

GAZOPHYLACIUM XIII (svezak 3-4) (2008) 23-27.

157. B. Hanžek, I. Soljačić i N. Trinajstić

"Hrvatski kemičari. II. Karlo Weber"

KEM. IND. 58 (2009) 1-10. 
158. N. Trinajstić, M. Kaštelan-Macan, S. Paušek-Baždar i H. Vančik "Hrvatska kemija u XX. stoljeću. II. dio. Razdoblje od sloma Nezavisne Države Hrvatske 8. svibnja 1945. do uspostave Republike Hrvatske 25. lipnja 1991.

KEM. IND. 58 (2009) 315-336.

159. N. Trinajstić

Najcitiraniji radovi hrvatskih terijskih kemičara

KEM. IN D. 58 (2009) 343.

160. N. Trinajstić

"Iz života i znanstvenoga rada Leopolda Ružičke, prvoga Hrvata dobitnika Nobelove nagrade" PRIRODOSLOVLJE 9 (2009) 3-24.

161. S. Paušek-Baždar i N. Trinajstić

"Hrvatska kemija u XIX. stoljeću"

$\mathrm{u}$ :HRVATSKA I EUROPA - KULTURA. ZNANOST I UMJETNOST

Svezak IV: Moderna hrvatska kultura od Preporoda do Moderne (XIX. stoljeće)

Urednici: Josip Bratulić, Josip Vončina i Antun Dubravko Jelčić

Školska knjiga, Zagreb, 2009., str. 715-720.

162. N. Trinajstić

"Ein Buch, das es wert ist, gelesen zu werden"

aus "Betrachtung über Wissenschaft und Wissenschatler"

Članak je stavljen na web stranicu Profesora Helmutha Moritza u svibnju 2010.

www.helmuth-moritz.at

Prijevod Norberta Zsifkovitsa s hrvatskoga članka Knjiga koju valja pročitati, koji je preuzet

iz knjige Ogledi o znanosti i znanstvenicima, Matica hrvatska, Zagreb, 1998., str. 160-176.

163. N. Trinajstić

"Ivan Gutman - kemičar i matematičar"

u: UGLEDNI HRVATSKI ZNANSTVENICI U SVIJETU - peti dio

urednik: Janko Herak

Hrvatsko-američko društvo i Hrvatska matica iseljenika, Zagreb, 2010.

Hrvatski tekst - str. 87-102

Engleski prijevod - str. 247-262

164. N. Trinajstić

"Pedeseta obljetnica izlaženja časopisa Američkoga kemijskoga društva Journal of

Chemical Information and Modeling"

KEM. IND. 59 (2010) 402.

165. N. Trinajstić, S. Nikolić, A . Miličević, I. Gutman,

"O Zagrebačkim indeksima"

KEM. IND. 59 (2010) 577-589.

166. N. Trinajstić

"Zlatko Meić - dobitnik Godišnje državne nagrade za znanost 2006. "

KEM. IND. 59 (2010) 599-605. 
167. N. Trinajstić,

"Božo Težak i Croatica Chemica Acta"

u: GODINA BOŽE TEŽAKA, Zagreb, 2010., str. 28-30;

168. I. Soljačić, B. Hanžek, N. Trinajstić

"Karlo Weber (1902.-1978.) - istaknuti hrvatski kemičar, žrtva komunističke represije"

GODIŠNJAK NJEMAČKE ZAJEDNICE 17 (2010) 163-176,

169. B. Lučić, N. Trinajstić

"Most Cited Papers in Croatica Chemica Acta"

CROAT. CHEM. ACTA 83 (2010) CCCVII-CCCXII.

170. N. Trinajstić

"In memorian - Akademik Dionis Emerik Sunko (1922.-2010.)

PRIRODA 101 (1) (2011) 46-47.

171. N. Trinajstić

"Dionis Emerik Sunko (26. rujna 1922. - 16. srpnja 2010. "

AMAC UNIVERSITATIS ZAGREBIENSIS 12 (17) (2010) 15.

172. N. Trinajstić

"Jean Paul Brenet"

LJETOPIS HRVATSKE AKADEMIJE 113 (2010) 555-556.

173. N. Trinajstić

"Dionis Emerik Sunko (1922.-2010.)"

LJETOPIS HRVATSKE AKADEMIJE 114 (2011) 829-831.

174. N. Trinajstić, S. Paušek-Baždar, V. Flegar

"150 godina Hrvatske akademije znanosti i umjetnosti i 125 godina prisutnosti kemičara u Akademiji"

KEM. IND. 60 (2011) 447-457.

175. N. Trinajstić

"Dionis Emerik Sunko"

u: DIONIS EMERIK SUNKO (1922.-2010.)

urednik: N. Trinajstić

HAZU, Zagreb, 2011., str. 9-12.

176. N. Trinajstić, M. Kaštelan-Macan, S. Paušek-Baždar, H. Vančik

"Hrvatska kemija u XX. stoljeću. III. dio. Razdoblje od uspostave Republike Hrvatske 25.

lipnja 1991. do kraja stoljeća"

KEM. IND. 61 (2012) 523-533.

177 N. Trinajstić

"Sjećanje na Antu Graovca"

KEM. IND. 62 (2013) 119-120. 
178. S. Paušek-Baždar, N. Trinajstić

"Križevačko učilište i prvo institucionaliziranje kemijskih (lučbenih) istraživanja u Hrvatskoj" PRIRODOSLOVLJE 13 (2013) 31-42.

179. N. Trinajstić

"Douglas Jay Klein - Curriculum Vitae"

CROAT. CHEM. ACTA 86 (2013) CCCCXIX.

180. N. Trinajstić

"Remebering Ante Graovac"

In: ANTE GRAOVAC - LIFE AND WORK

Edited by I. Gutman, B. Pokrić, D. Vukičević

University of Kragujevac, Kragujevac, 2014, pp. 73-79.

181. N. Trinajstić

"Akademik Smiljko Ašperger"

ANALI

Zavod za znanstveni i umjetnički rad, Osijek, 2011. (tiskan 2014.), sv. 21, str. 31-42.

182. N. Trinajstić

"Akademik Smiljko Ašperger (Zagreb, 25. siječnja 1921.-Zagreb, 3. svibnja 2014.)" KEM. IND. 63 (2014) 293-297.

183. N. Trinajstić, V. Flegar

"Konstantin Georgijević i Zvonimir Pinterović, doktori kemije"

PRIRODOSLOVLJE 14 (2014) 69-86.

184. N. Trinajstić

"Akademik Smiljko Ašperger (Zagreb, 25. siječnja 1921.-Zagreb, 3. svibnja 2014.)"

U SPOMENICI SMILJKO AS̆PDRGER 1921.-2014.

Urednik Leo Klasinc

HAZU, Zagreb 2015., str. 23-38.

185. N. Trinajstić

"Akademik Nikola Kallay"

U SPOMENICI NIKOLA KALLAY 1942.-2015.

Urednik N. Trinajstić

HAZU, Zagreb 2016., str. 11-14.

186. N. Trinajstić, S. Paušek-Baždar

"Hrvatska kemija u XX. stoljeću"

u: HRVATSKA I EUROPA - KULTURA. ZNANOST I UMJETNOST Svezak V. 


\section{Nenad Trinajstić}

\section{Papers in Books and Proceedings}

1. R. B. Mallion, A. J. Schwenk and N. Trinajstić

"On the Characteristic Polynomial of a Rooted Graph", in: RECENT ADVANCES IN GRAPH THEORY

Proceedings of the Second Czechoslovak Symposium on Graph Theory

Editor M. Fiedler

Academia, Prague, 345-350 (1975).

2. N. Trinajstić

"Calculation of Spin Density Distribution in Planar Radicals"

in: MAGNETIC RESONANCE IN CHEMISTRY AND BIOLOGY

Edited by J. N. Herak and K. J. Adamić

Dekker, New York, 97-125 (1975).

3. H. Güsten, L. Klasinc, J. V. Knop and N. Trinajstić

"Application of Photoelectron Spectrometry to Biologically Active Molecules and Their Constituent Parts. I. Indoles"

in: EXCITED STATES OF BIOLOGICAL MOLECULES

Edited by J. B. Birks

Wiley, Chichester, Sussex, 45-49 (1975).

4. J. Koller, A. Ažman and N. Trinajstić

"Ab Initio Molecular Orbital Studies in Quantum Biology. Electronic Characteristics if Indole and Benzofuran"

in: QUANTITATIVE STRUCTURE-ACTIVITY RELATIONSHIPS,

Proceedings of the Conference on Chemical Structure-Biological Activity Relationships:

Quantitative Approach

Edited by M. Tichy

Akademiai Kiado, Budapest, 205-209 (1976).

5. N. Trinajstić

"Hückel Theory and Topology"

in: Semiempirical Methods of Electronic Structure Calculation. Part A: Techniques

Edited by G. A. Segal

MODERN THEORETICAL CHEMISTRY, Vol. 7

Plenum, New York, 1-27 (1977).

6. A. Graovac, M. Randić and N. Trinajstić

"Graph-Theoretical Approach to the Estimation of the Energy Gap of Polymeric Conjugated Hydrocarbons"

in: Quasi One-Dimensional Conductors II., LECTURE NOTES IN PHYSICS, Vol. 96

Edited by S. Barišić, A. Bjeliš, J. R. Cooper, and B. Leontić

Springer-Verlag, Berlin, 450-455 (1979).

7. B. Džonova-Jerman-Blažič, B. Mohar and N. Trinajstić

"Algorithms for Symbolic Computation in Chemistry: Computing the Acyclic Polynomial of Molecular Graph"

in: APPLICATIONS OF INFORMATION AND CONTROL SYSTEMS

Edited by D. G. Lainiotis and N. S. Tzannes

D. Reidel Publ. Co., Dordrecht, Holland, 395-402 (1980). 
8. M. Randić, V. Katović and N. Trinajstić

"Symmetry Properties of Chemical Graphs. VII. Enantiomers of a Tetragonal-Pyramidal Rearrangement"

in: SYMMETRIES AND PROPERTIES OF NON-RIGID MOLECULES: A COMPREHENSIVE SURVEY

Edited by J. Maruani and J. Serre

Elsevier, Amsterdam, 1983, pp. 399-408.

9. M. Barysz, G. Jashari, R. S. Lall, V. K. Srivastava and N. Trinajstić

"On the Distance Matrix of Molecules Containing Heteroatoms"

in: CHEMICAL APPLICATIONS OF TOPOLOGY AND GRAPH THEORY

Edited by R. B. King

Elsevier, Amsterdam 1983, pp. 222-230.

10. N. Trinajstić and P. Krivka

"On The Reduced Graph Model"

in: MATHEMATICS AND COMPUTATIONAL CONCEPTS IN CHEMISTRY

Edited by N. Trinajstić

Horwood, Chichester 1986, pp. 328-345

11. N. Bošnjak, N. Adler, M. Perić and N. Trinajstić

"On the Structural Origin of Chromatographic Retention Data: Alkanes and Cycloalkanes"

in: MODELLING OF STRUCTURE AND PROPERTIES OF MOLECULES

Edited by Z. B. Maksić, Horwood, Chichester 1987, pp. 103-122.

12. M. Randić, S. Nikolić and N. Trinajstić

"The Conjugated Circuits Model: On the Selection of the Parameters for Computing the Resonance Energies"

in: "GRAPH THEORY AND TOPOLOGY IN CHEMISTRY"

Edited by R. B. King and D. H. Rouvray

Elsevier, Amsterdam, 1987, pp. 429-447

13. N. Trinajstić

"Of Models and Graphs"

in: MATH/CHEM/COMP 1987

Edited by R. C. Lacher

Elsevier, Amsterdam, 1988, pp. 83-100.

14. M. Randić and N. Trinajstić

"On Conjugated Chains"

in: MATH/CHEM/COMP 1987

Edited by R. C. Lacher

Elsevier, Amsterdam, 1988, pp. 109-123.

15. K. Kovačević D. Plavšić, N. Trinajstić and D. Horvat

"On the Intercorrelation of Topological Indices"

in: MATH/CHEM/COMP 1988

Edited by A. Graovac

Elsevier, Amsterdam, 1989, pp. 213-224. 
16. N. Adler, L. Kovačić-Beck and N. Trinajstić

"On the Correlation Between Graph-theoretical Indices and Physical Properties of Hydrocarbons.

Prediction of Densities of n-Alkane Mixtures"

in: MATH/CHEM/COMP 1988

Edited by A. Graovac

Elsevier, Amsterdam, 1989, pp. 225-234.

17. S. Carter, S. Nikolić and N. Trinajstić

"A QSAR Study of the Anti-tumouric Activity of Phenyltriazines"

in: MATH/CHEM/COMP 1988

Edited by A. Graovac

Elsevier, Amsterdam, 1989, pp. 255-264.

18. N. Trinajstić

"On the Scientific Method"

in: MATH/CHEM/COMP 1988

Edited by A. Graovac

Elsevier, Amsterdam, 1989, pp. 557-568.

19. J. V. Knop, W. R. Müller, K. Szymanski, S. Nikolić and N. Trinajstić

"Computer-Oriented Molecular Codes"

in: COMPUTATIONAL CHEMICAL GRAPH THEORY

Edited by D. H. Rouvray

Nova Science Publishers, New York, 1990, pp. 9-32

20. N. Trinajstić

"Graph Theory and Molecular Orbitals"

in: CHEMICAL GRAPH THEORY: INTRODUCTION AND FUNDAMENTALS

Edited by D. Bonchev and D. H. Rouvray

Abacus Press - Gordon \& Breach, New York, 1991, 235-279.

21. N. Trinajstić

"Fivefold Symmetry in the Literature"

in: FIVEFOLD SYMMETRY

Edited by I. Hargittai

World Scientific, Singapore, 1992, 395-405

22. N. Trinajstić, D. Babić, S. Nikolić and Z. Mihalić

"Symmetry of Molecules"

in: CHEMICAL GROUP THEORY: INTRODUCTION AND FUNDAMENTALS

Edited by D. Bonchev and D. H. Rouvray

Gordon \& Breach, Amsterdam, 1994, 133-158.

23. N. Trinajstić, Z. Mihalić and A. Graovac

"The Interplay Between Graph Theory and Molecular Orbital Theory"

in: GRAPH-THEORETICAL APPROACHES TO CHEMICAL REACTIVITY

Edited by D. Bonchev and O. Mekenyan

Kluwer Academic Publishers, Dordrecht, 1994, 37-72. 
24. S. Rendić, M. Medić-Šarić, S. Nikolić and N. Trinajstić

Organic Explosives as Dangerous Environmental Xenobiotics - QSAR Study"

in: ENVIRONMENTAL XENOBIOTICS

Edited by Mervyn Richardson

Taylor \& Francis, London, 1996, pp. 289-312.

25. N. Trinajstić

"Mathematics and Chemistry - the Unlikely Partners"

in: CONCEPTS IN CHEMISTRY - A CONTEMPORARY CHALLENGE

Edited by D. H. Rouvray

Wiley, New York, 1997, pp. 17-39.

26. B. Lučić, N. Trinajstić and D. Juretić

"Recognition of Membrane Protein Structure from Amino Acid Sequence"

in: FROM CHEMICAL TOPOLOGY TO THREE-DIMENSIONAL GEOMETRY

Edited by A. T. Balaban

Plenum Press, New York, 1997, pp. 117-158.

27. D. Juretić, B. Lučić, D. Zucić and N. Trinajstić

"Protein Transmembrane Structure: Recognition and Prediction by Using Hydrophobicity Scales through Preference Functions"

in: THEORETICAL ORGANIC CHEMISTRY

Edited by C. Párkányi

Elsevier, Amsterdam, 1998, pp. 405-445.

28. S. Nikolić, N. Trinajstić and Z. Mihalić

"The Detour Matrix and the Detour Index"

in: TOPOLOGICAL INDICES AND RELATED DESCRIPTORS IN QSAR AND QSPR

Edited by J. Devillers and A. T. Balaban

Gordon and Breach Science Publishers, The Netherlands, 1999, 279-306.

29. S. Nikolić, N. Trinajstić, D. Amić, D. Bešlo and S. C. Basak

"Modeling Solubility of Aliphatic Alcohols in Water. Graph Connectivity Indices versus Line

Graph Connectivity Indices"

in: QSPR/QSAR STUDIES BY MOLECULAR DESCRIPTORS

Edited by M. V. Diudea

Nova Science Publishers, Huntington, 2001, pp. 63-81.

31. D. J. Klein, D. Babić and N. Trinajstić

"Enumeration in Chemistry"

in: CHEMICAL MODELLING: APPLICATIONS AND THEORY

Edited by A. Hinchliffe

The Royal Society of Chemistry, London, 2002., Vol. 2, pp. 56-95.

32. S. Nikolić, N. Trinajstić, I. M. Tolić, G. Rücker and C. Rücker

"On Molecular Complexity Indices"

in: COMPLEXITY - INTRODUCTION AND FUNDAMENTALS

Edited by D. Bonchev and D. H. Rouvray

Taylor \& Francis, London, 2003, pp. 29-89. 
33. D. Babić, D. J. Klein, J. von Knop and N. Trinajstić

"Combinatorial Enumeration in Chemistry"

in: CHEMICAL MODELLING: APPLICATIONS AND THEORY

Edited by A. Hinchliffe

The Royal Society of Chemistry, London, 2004, Vol. 3, pp. 126-170.

34. A. Miličević and N. Trinajstić

"Combinatorial Enumeration in Chemistry"

in: CHEMICAL MODELLING: APPLICATIONS AND THEORY

Edited by A. Hinchliffe

The Royal Society of Chemistry, London, 2006, Vol. 4, pp. 405-469.

35. N. Trinajstić

"Božidar Rogina (1901.-1967.) - pionir prehrambene kemije u Hrvatskoj"

u: RADOVI ZAVODA ZA ZNANSTVENOISTRAŽIVAČKI I UMJETNIČKI RAD U

BJELOVARU

Glavni i odgovorni urednik: Slobodan Kaštela

Zagreb - Bjelovar, 2007., str. 191-204.

36. N. Trinajstić

"Vlasta Bonačić-Koutecký: putovanje od Splita i Zagreba do Berlina preko Baltimorea i New Yorka"

u: UGLEDNI HRVATSKI ZNANSTVENICI U SVIJETU, IV. Dio

urednik: Janko Herak

Hrvatsko-američko društvo, Hrvatska matica iseljenika i Farmaceutsko-biokemijski fakultet, Zagreb, 2008.

Hrvatski tekst - str. 9-16

Engleski prijevod - str. 87-95.

37. B. Lučić, D. Amić and N. Trinajstić

"Antioxidant QSAR Methodology as Exemplified on Polyphenols"

in: SPRINGER PROTOCOLS - METHODS IN MOLECULAR BIOLOGY,

Vol. 477: ADVANCED PROTOCOLS IN OXIDATIVE STRESS I

Edited by D. Armstrong

Humana Press, New York, 2008, Chapter 16, pp. 207-218.

38. N. Trinajstić

"Životni put Akademika Vinka Škarića"

u: SPOMENICI PREMINULIM AKADEMICIMA - VINKO ŠKARIĆ 1923.-2006.

urednik: K. Ilakovac

HAZU, Zagreb, 2008, str. 9-12.

39. S. Nikolić, N. Trinajstić and B. Zhou

"On the Eigenvalues of the Ordinary and Reciprocal Resistance-Distance Matrices"

in: COMPUTATIONAL METHODS IN SCIENCE AND ENGINEERING

Edited by G. Maroulis and T. E. Simos

American Institute of Physics, Melville, New York, 2009, Vol. 1, pp. 205-214. 
40. D. Janežič, A. Miličević, S. Nikolić and N. Trinajstić

"Topological Complexity of Molecules"

in: ENCYCLOPEDIA OF COMPLEXITY AND SYSTEMS SCIENCE

Editor: Robert Meyers

Section: COMPLEXITY IN COMPUTATIONAL CHEMISTRY

Section editor: Danail Bonchev

Springer, New York, 2009., Vol. 10, pp. 9210-9224.

41. S. Paušek-Baždar i N. Trinajstić

"Prirodoslovni rad Ivana Leopolda Payera"

u: 800 GODINA SLOBODNOGA KRALJEVSKOGA GRADA VARAŽDINA 1209.-2009.

Glavni urednici: Miroslav Šicel i Slobodan Kaštela

HAZU, Grad Varaždin i Vraždinska županija, 2009., str. 831-838.

42. N. Trinajstić

"On Models and Modeling in Chemistry"

u: MATHEMATICAL METHODS AND MODELLING FOR STUDENTS OF

CHEMISTRY AND BIOLOGY

Editors: Ante Graovac, Ivan Gutman and Damir Vukičević

University of Dubrovnik, University of Split, Rugjer Bošković Institute and Hum naklada

d.o.o., Zagreb, 2009, pp. 1-11.

43. N. Trinajstić

"Božo Težak i Croatica Chemica Acta"

u: GODINA BOŽE TEŽAKA 2007.

Zagreb 2010., str. 28-30.

44. B. Lučić, S. Nikolić, N. Trinajstić, B. Zhou, S. Ivaniš Turk,

"Sum-Connectivity Index"

in: NOVEL MOLECULAR STRUCTURES DESCRIPTORS - THEORY AND APPLICATIONS

I. Gutman, B. Furtula, eds., University of Kragujevac, Kragujevac, Serbia, 2010., pp. 101-136.

45. Bono Lučić, Ante Miličević, Sonja Nikolić and Nenad Trinajstić

"Coding and Ordering Benzenoids and Their Kekulé Structures"

in: CARBON BONDING AND STRUCTURES: ADVANCES IN PHYSICS AND

CHEMISTRY, M. V. Putz, ed., Dordrecht,. Springer, 2011, pp. 205-225.

46. N. Trinajstić

Od Tehničkoga fakulteta do povezanosti s Institutom Rugjer Bošković, u: Vatroslav Lopašić -

klasik hrvatske fizike

Urednici Branko Hanžek, Zvonko Benčić,

Kiklos, Zagreb, 2011., str. 383-384.

47. B. Zhou, Z. Du and N. Trinajstić

"Harary Index of Landscape Graphs"

in: ADVANCES IN CHEMICAL MODELING 1 (2011) 229-237.

M. V. Putz, Editor, Nova Science Publishers, Hauppauge, NY. 
48. B. Zhou and N. Trinajstić

"Estrada Index of Bipartite Graphs"

in: ADVANCES IN CHEMICAL MODELING 1 (2011) 239-246.

M. V. Putz, Editor, Nova Science Publishers, Hauppauge, NY.

49. B. Lučić, I. Sović, D. Plavšić and N, Trinajstić

"Harary Matrices: Definitions, Properties and Applications"

in: DISTANCE IN MOLECULAR GRAPHS - APPLICATIONS

I. Gutman, B. Furtula, eds., University of Kragujevac, Kragujevac, 2012., pp. 3-26.

50. B. Lučić, S. Nikolić and N. Trinajstić

"Zagreb Indices"

in: CHEMICAL INFORMATION AND COMPUTATIONAL CHALLENGES IN THE 21st CENTURY, M. V. Putz, ed., Nova, 2012, pp. 261-275.

51. S. Nikolić, N. Trinajstić and S. Ivaniš Turk

"On Addtive Version of the Connectivity Index"

AMERICAN INSTITUTE OF PHYSICS - CONFERENCE

PROCEEDINGS 1504 (2012) 342-350.

52. B. Zhou and N. Trinajstić

"On Altered Wiener Indices of Trees and Molecular Trees"

In: ADVANCES IN CHEMICAL MODELING 3 (2013) 201-211.

M. V. Putz, Editor, Nova Science Publishers, Hauppauge, NY, 2013.

53. S. Feretić and N. Trinajstić

"The Area Generating Function for Simple-2-column Polyominoes with Hexagonal Cells"

In: ADVANCES IN CHEMICAL MODELING 3 (2013) 275-289.

M. V. Putz, Editor, Nova Science Publishers, Hauppauge, NY, 2013.

54. B. Lučić, I. Sović and N. Trinajstić

"The Four Conectivity Matrices, Their Indices, Polynomials and Spectra"

In: AVANCES IN MATHEMATICAL CHEMISTRY AND APPLICATIONS 1 (2014) 76-91.

Editors: S. C. Basak, G. Restrepo and J. L. Villaveces

55. D. Janežič, A. Miličević, S. Nikolić and N. Trinajstić

"Topological Complexity of Molecules"

in: ENCYCLOPEDIA OF COMPLEXITY AND SYSTEMS SCIENCE

Editor: Robert Meyers

Section: COMPLEXITY IN COMPUTATIONAL CHEMISTRY

Section editor: Danail Bonchev

Springer, New York, 2014, $2^{\text {nd }}$ edition, Vol. 10, pp. 9210-9224.

56. B. Lučić, I. Sović, N. Trinajstić

"On Coding and Ordering Benzenoids and Their Kekulé Structures by Using the Kekulé Index and Some Relatred Codes"

In: ANTE GRAOVAC - LIFE AND WORK

Edited by I. Gutman, B. Pokrić, D. Vukičević

University of Kragujevac, Kragujevac, 2014, pp. 163-178. 


\section{Book reviews, obituaries and other articles starting (only) from 2002}

12. N. Trinajstić

Book Review - Drago Grdenić: Povijest kemije (The History of Chemistry)

CROAT. CHEM. ACTA 75 (2002) A33-A37.

13. N. Trinajstić

Nova knjiga Drage Grdenića: Povijest kemije

POLIMERI 23 (2002) 26-27.

14. N. Trinajstić

Prikaz knjige - Janko Herak (urednik): Istaknuti hrvatski znanstvenici u svijetu.- I. dio KEM IND. 51 (2002) 299.

15. N. Trinajstić

Prvi broj časopisa Prirodoslovlje

KEM IND. 51 (2002) 300.

16. N. Trinajstić

Book Review — Drago Grdenić: Povijest kemije

AMBIX 50 (2003) 123-124.

17. N. Trinajstić, S. Turina i J. Varljen

Nekrolog — Želimir Procházka (Dubrovnik, 1921, - Prag, 2003.)

GLASNIK AMACIZ-a 31 (2003) 24-25.

18. N. Trinajstić

Obituary — Krešimir Balenović (1914-2003)

ACTA PHARM. 53 (2003) 239-240.

19. N. Trinajstić

Obituary — Krešimir Balenović (1914-2003)

CROAT. CHEM. ACTA 76 (2003) A3-A4.

20. N. Trinajstić

Nekrolog — Krešimir Balenović (1914.-2003.)

FARMACEUTSKI GLASNIK 59 (2003) 129-130.

21. N. Trinajstić, S. Turina and J. Varljen

"Obituary - Želimir Procházka (1921.-2003.)"

CROAT. CHEM. ACTA 76 (2003) A33-A35.

22. N. Trinajstić

Nekrolog — Krešimir Balenović (1914.-2003.)

LJETOPIS HRVATSKE AKADEMIJE 107 (2004) 417-420. 
23. N. Trinajstić

Prikaz knjige - Janko Herak (urednik): Istaknuti hrvatski znanstvenici u svijetu.- I. dio KEM IND. 53 (2004) 35.

24. N. Trinajstić

Book Review - Smiljko Ašperger: Chemical Kinetics and

Inorganic Reactions Mechanisms

CROAT. CHEM. ACTA 77 (2004) A9.

25. N. Trinajstić

Book Review - Chemistry and Mathematics: Two Scientific Languages of the 21st

Century

CROAT. CHEM. ACTA 77 (2004) A11.

26. N. Trinajstić

Proslov: Novi broj časopisa Prirodoslovlje s novim Uredništvom

PRIRODOSLOVLJE 5 (2005) 1.

27. N. Trinajstić

Obituary - Marko Branica (1931-2004)

CROAT. CHEM. ACTA 78 (2005) A1-A2.

28. N. Trinajstić

Book Review - M. Kaštelan-Macan: Vizionari kemijsko-tehnološkoga studija

(Visionaries of Chemical Technological Studies)

CROAT. CHEM. ACTA 78 (2005) A13-A14.

29. M. Herceg-Rajačić and N. Trinajstić

Obituary - Boris Matković (1927-2005)

CROAT. CHEM. ACTA 78 (2005) A27-A28.

30. N. Trinajstić

Obituary - Dragutin Fleš (1921-2005)

CROAT. CHEM. ACTA 78 (2005) A29-A30.

31. N. Trinajstić

Obituary - Zdravko Pusko Ježić (1931-2005)

CROAT. CHEM. ACTA 78 (2005) A31-A32.

32. N. Trinajstić

Obituary - Vinko Škarić (1923-2006)

CROAT. CHEM. ACTA 79 (2006) A3-A4.

33. N. Trinajstić

Book Review -X. Li, I. Gutman: Mathematical Aspects of Randić-type Molecular Structure Descriptors

CROAT. CHEM. ACTA 79 (2006) A31-A32. 
34. N. Trinajstić

Book Reviews - M. Mintas, S. Raić-Malić, N. Raos: Načela dizajniranja ljekova i M. Mintas, S. Raić-Malić, N. Raos: Lijekovi u prostoru - farmakofori i receptori

CROAT. CHEM. ACTA 80 (2007) A1.

35 N. Trinajstić

Book Review - L. Pogliani: Numbers Zero, One, two and Three in Science and Humanities CROAT. CHEM. ACTA 80 (2007) A25-A26.

36 N. Trinajstić

Obituary - István Lukovits (1945-2007)

CROAT. CHEM. ACTA 80 (2007) A27.

37. N. Trinajstić

Prikaz knjige - Vladimir Prelog i hrvatska kemija

Zbornik radova

Urednik: D. Škare

HKDI/Kema u industriji, Zagreb, 2007., VI + 90 stranica

KEM. IND. 56 (2007) 468-469.

38. N. Trinajstić

Hrvatski prirodoslovci 16

PRIRODOSLOVLJE 7 (2007) 1-2.

39. N. Trinajstić

Book Review - Vladimir i hrvatska kemija (Vladimir Prelog and Croatian Chemistry)

CROAT. CHEM. ACTA 80 (2007) A33-A34.

39. N. Trinajstić

Book Review - Shinsaku Fujita: Diagrammatical Approach to Molecular Symmetry and Enumeration of Stereoiosomers

CROAT. CHEM. ACTA 81 (2008) A27-A28.

40. N. Trinajstić

Proslov - Hrvatski prirodoslovci 17

PRIRODOSLOVLJE 8 (2008) 1.

41. N. Trinajstić

Book Review - B. Pignataro (Editor): Tomorrow's Chemistry Today

CROAT. CHEM. ACTA 81 (2008) A33-A34.

42. N. Trinajstić

Book Review - Đ. Težak (Editor): Professor Božo Težak, the Torchbearer of Science

CROAT. CHEM. ACTA 81 (2008) A35-A36.

43. N. Trinajstić

Prikaz knjige - D. Amić: Organska kemija za studente agronomske struke

KEM. IND. 58 (2009) 417-418. 
44. N. Trinajstić,

Pozdravni govor u ime predsjednika HAZU na proslavi devedesete obljetnice Kemijskoinženjerskoga studija

KEM. IND. 58 (2009) 608-609.

44. N. Trinajstić

Vladimir Prelog's Heritage (Živa baština Vladimira Preloga)

CROAT. CHEM. ACTA 82 (2009) CXXXIII-CXXXIV.

45. N. Trinajstić

Festival znanosti u Sinju

PRIRODA 100 (2010) 18-19.

46. N. Trinajstić

Prikaz knjige - M. Mintas, S. Raić-Malić: Medicinska kemija

CROAT. CHEM. ACTA 83 (2010) CCVII.

47. N. Trinajstić

Book Review - M. Dumić, K. Kovačević: Ogledi o Vladimiru Prelogu

ACTA PHARM. 60 (2010) 369-372.

48. N. Trinajstić

Prikaz knjige - M. Dumić, K. Kovačević: Ogledi o Vladimiru Prelogu

FARMACEUTSKI GLASNIK 66 (2010) 513-516.

49. N. Trinajstić

Prikaz knjige - M. Dumić, K. Kovačević: Ogledi o Vladimiru Prelogu

KEM. IND. 59 (2010) 512-514.

50. N. Trinajstić

In Memoriam - Dionis Emerik Sunko (26. rujna 1922.-16. srpnja 2010.)

AMAC UNIVERSITATIS ZAGREBIENSIS 12 (2010) 15.

51. N. Trinajstić

Bez premca među hrvatskim tiskovinama

MERIDIJANI 150 (2010) 18.

50. N. Trinajstić

Book Review - M. Dumić, K. Kovačević: Ogledi o Vladimiru Prelogu Homage to Vladimir Prelog

CROAT. CHEM. ACTA 83 (2010) CCCCIX-CCCCXII.

51. N. Trinajstić

Prikaz knjige - O. Carević, D. Vikić-Topić, Znanost, humanost i ekologija FARMACEUTSKI GLASNIK 66 (2010) 703-704.

52. N. Trinajstić

Prikaz knjige - M. Mintas: Medicinska kemija protutumorskih lijekova

KEM. IND. 62 (2013) 206. 
53. N. Trinajstić

Prikaz knjige - H. Vančik: Temelji organske kemije

KEM. IND. 62 (2013) 207.

54. N. Trinajstić

Book Review - M. Mintas: Medicinska kemija protutumorskih lijekova (Medicinal Chemistry of Antitumouric Drugs)

CROAT. CHEM. ACTA 86 (2013) CIX-CX.

55. N. Trinajstić

Prikaz knjige - Marija Kaštelan-Macan: Srećko Turina-učitelj i prijatelj

KEM. IND. 62 (2013) 285.

56. D. Babić, A. T. Balaban, B. Lučić, N. Trinajstić

"Editorial for The Klein Festschrift"

CROAT. CHEM. ACTA 86 (2013) CCCCXVII. .

57. N. Trinajstić

"Douglas Jay Klein - Curriculum Vitae"

CROAT. CHEM. ACTA 86 (2013) CCCCXIX.

58. N. Trinajstić

"Uvodne riječi"

u: Boris Kamenar (1929.-2012.)

Uredio Akademik Stanko Popović

SPOMENICA PREMINULIM AKADEMICIMA 185 (2013) 9-11.

59. N. Trinajstić

Prikaz knjige - Olga Carević: Snaga prijateljstva

FARMACEUTSKI GLASNIK 71 (2015) 198-2000.

60. N. Trinajstić

"Egon Matijević (1922.-2016.)"

LJETOPIS HRVATSKE AKADEMIJE ZA GODINU 2016.

Knjiga 120, str. 1081.-1084.

Zagreb, 2017.

61. N. Trinajstić

Book Review - Ivan Gutman: Selected Theorems in Chemical Graph Theory

(Mathematical Chemistry Monographs, Vol. 18)

CROAT. CHEM. ACTA 89 (2016) 555. 